Prepared in cooperation with the Johnson County Stormwater Management Program

\title{
Water-Quality Variability and Constituent Transport in Streams of Johnson County, Kansas, Using Continuous Monitoring and Regression Models, 2003-11
}

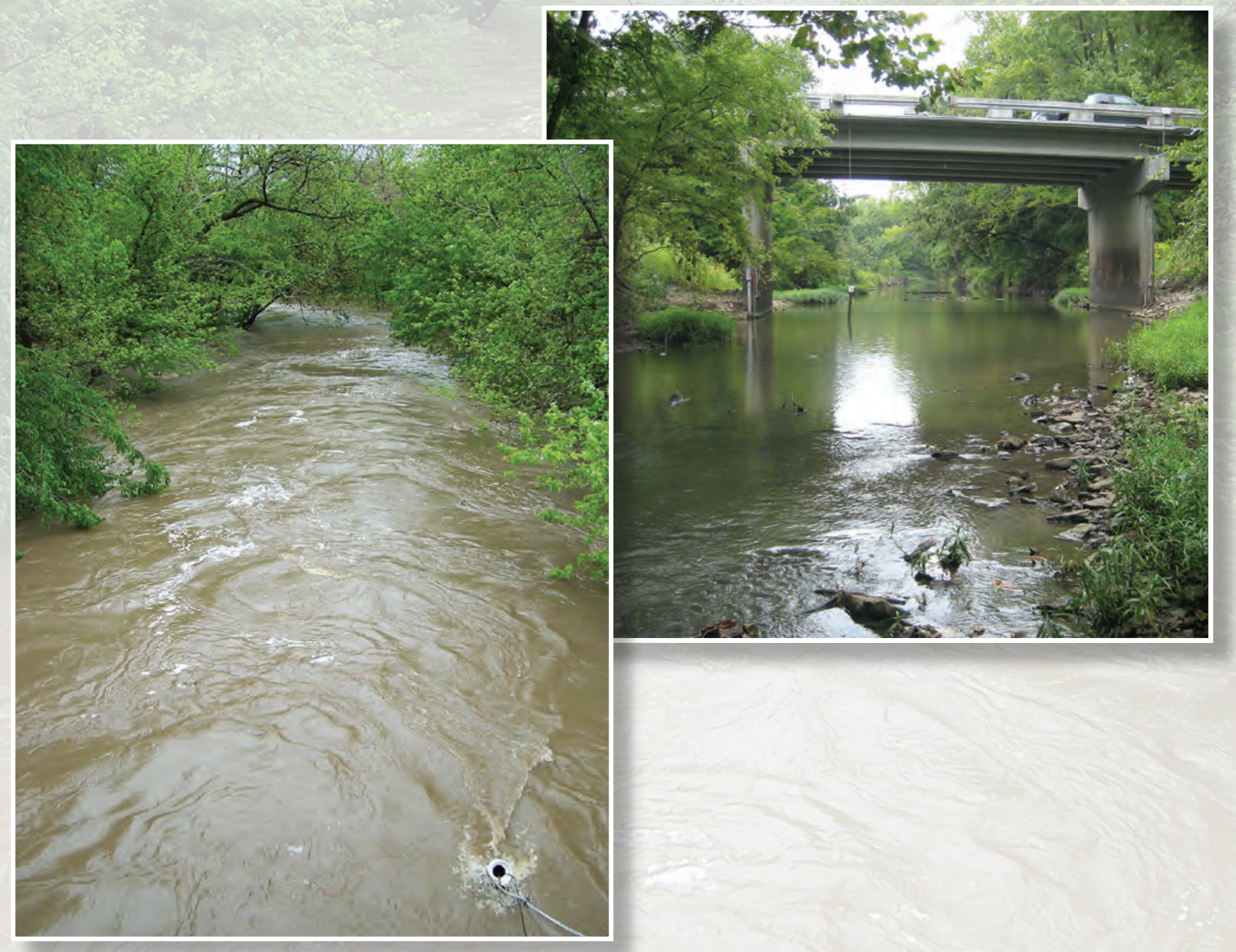

Scientific Investigations Report 2013-5221 
Front cover photographs. Upper left: Blue River at Kenneth Road during storm runoff, looking downstream from the bridge with continuous water-quality monitor in right foreground, May 2007 (photograph by Patrick Finnegan, U.S. Geological Survey). Lower right: Blue River at Kenneth Road during normal streamflow, looking upstream at the continuous water-quality monitor which is suspended from the bridge, April 2010 (photograph by Mandy Stone, U.S. Geological Survey).

Back cover photographs. Upper left: U.S. Geological Survey technician cleans a water-quality monitor, Blue River, 2010 (photograph by Betsy Siess, U.S. Geological Survey). Lower right: U.S. Geological Survey technician services a water-quality monitor, Mill Creek, 2004 (photograph by Patrick Finnegan, U.S. Geological Survey). Center: Water-quality monitor. 


\section{Water-Quality Variability and Constituent Transport in Streams of Johnson County, Kansas, Using Continuous Monitoring and Regression Models, 2003-11}

By Teresa Rasmussen and Jackline Gatotho

Prepared in cooperation with the Johnson County Stormwater Management

Program

Scientific Investigations Report 2013-5221 


\title{
U.S. Department of the Interior SALLY JEWELL, Secretary
}

\section{U.S. Geological Survey Suzette M. Kimball, Acting Director}

\author{
U.S. Geological Survey, Reston, Virginia: 2014
}

For more information on the USGS - the Federal source for science about the Earth, its natural and living resources, natural hazards, and the environment, visit http://www.usgs.gov or call 1-888-ASK-USGS.

For an overview of USGS information products, including maps, imagery, and publications, visit http://www.usgs.gov/pubprod

To order this and other USGS information products, visit http://store.usgs.gov

Any use of trade, firm, or product names is for descriptive purposes only and does not imply endorsement by the U.S. Government.

Although this information product, for the most part, is in the public domain, it also may contain copyrighted materials as noted in the text. Permission to reproduce copyrighted items must be secured from the copyright owner.

Suggested citation:

Rasmussen, T.J., and Gatotho, J., 2014, Water-quality variability and constituent transport and processes in streams of Johnson County, Kansas, using continuous monitoring and regression models, 2003-11: U.S. Geological Survey Scientific Investigations Report 2013-5221, p. 53, http://dx.doi.org/10.3133/sir20135221.

ISSN 2328-0328 (online) 


\section{Contents}

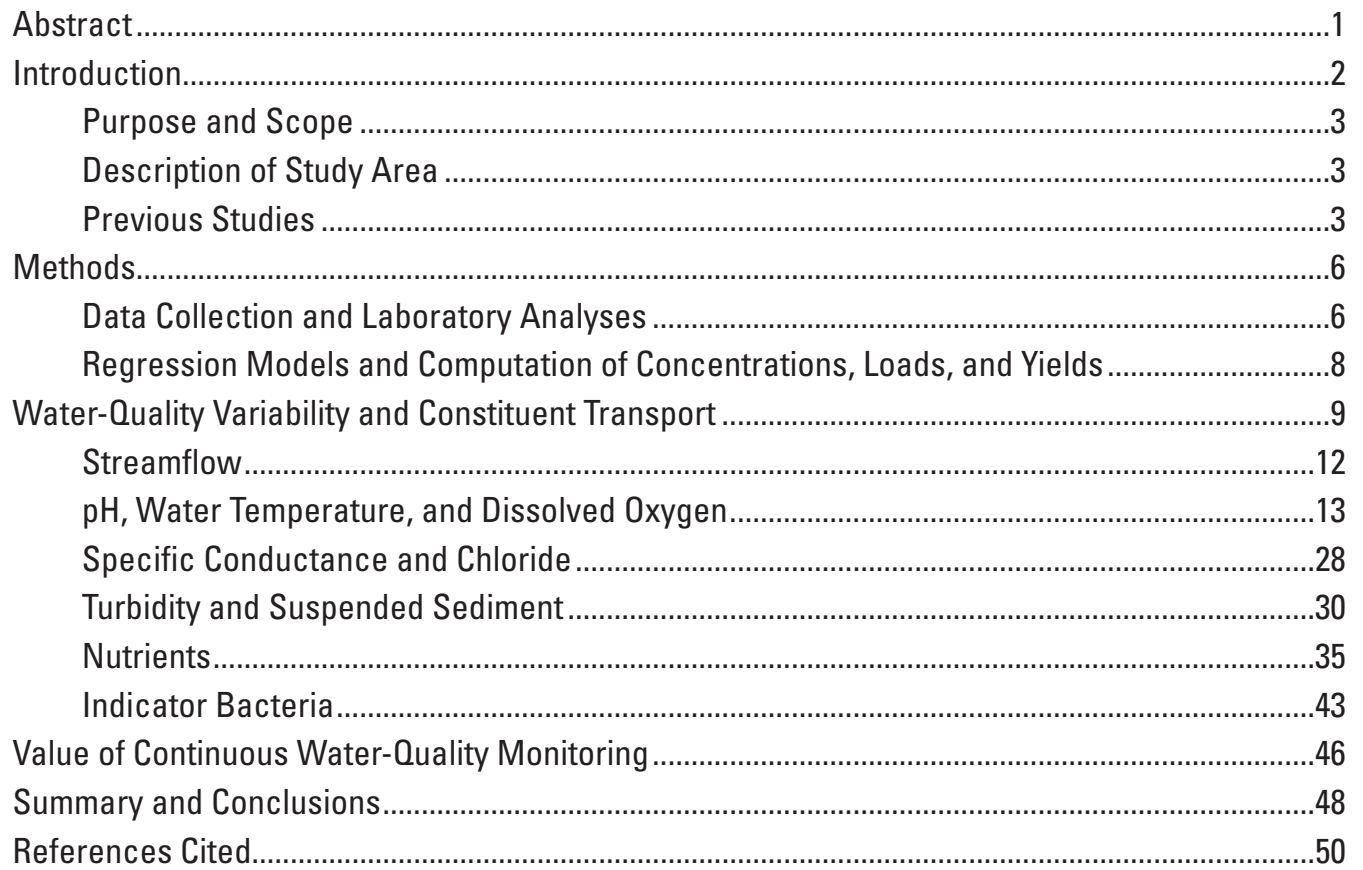

\section{Figures}

1. Map showing location of monitoring sites, watershed boundaries, and land use, Johnson County, Kansas

2. Photographs showing, continuous water-quality monitor, and monitoring sites and equipment in the Blue River, Cedar Creek, Indian Creek, Kill Creek, and Mill Creek, in Johnson County, Kansas...

3. Graph showing hourly streamflow and turbidity at the Indian Creek monitoring site, in Johnson County, Kansas, June through August 2008.

4. Graphs showing regression models showing explanatory and response variables, discrete data, and prediction intervals for chloride, suspended sediment, and Escherichia coli bacteria...

5. Graphs showing regression models and best-fit lines for total nitrogen and total phosphorus, showing discretely measured values and computed values......................11

6. Graphs showing monthly and annual precipitation in Olathe, Kansas, 2003-11 ............12

7. Graphs showing continuous daily values for streamflow $\mathrm{pH}$, water temperature, dissolved oxygen, specific conductance, and turbidity at monitoring sites in Johnson County, Kansas, 2003-11

8. Graphs showing period-of-record duration curves for hourly measured streamflow, $\mathrm{pH}$, water temperature, dissolved oxygen, specific conductance, and turbidity at monitoring sites in Johnson County, Kansas, 2003-11 
9. Graphs showing variability in hourly streamflow, $\mathrm{pH}$, water temperature, dissolved oxygen, specific conductance, and turbidity during base flow at the Mill Creek monitoring site, Johnson County, Kansas.

10. Graphs showing variability in rural and urban streams, including streamflow, water temperature, dissolved oxygen, specific conductance, chloride, and suspended sediment during winter and summer, Johnson County, Kansas.

11. Graphs showing relations between percent impervious surface area and annual yields for streamflow, chloride, suspended sediment, and Escherichia coli bacteria at stream monitoring sites in Johnson County, Kansas ..

12. Graphs showing annual hourly duration curves for dissolved oxygen at the Blue River monitoring site and specific conductance at the Indian Creek monitoring site, in Johnson County, Kansas, 2004-11.

13. Box plots showing computed hourly chloride concentrations by year and month at continuous water-quality monitoring sites in Johnson County, Kansas, 2003-11 .31

14. Graph showing computed hourly chloride concentrations at the Indian Creek monitoring site, Johnson County, Kansas, during December, January, and February, 2004-11

15. Graphs showing annual loads and yields using hourly computed data for chloride, suspended sediment, total nitrogen, total phosphorus, and Escherichia coli bacteria, 2003-11...

16. Box plots showing computed hourly suspended-sediment concentrations by year and month at continuous water-quality monitoring sites in Johnson County, Kansas, 2003-11

17. Graphs showing cumulative annual suspended-sediment load at monitoring sites in Johnson County, Kansas, 2003-11.

18. Box plots showing computed hourly total nitrogen concentrations by year and month at continuous water-quality monitoring sites in Johnson County, Kansas, 2003-11

19. Box plots showing computed hourly total phosphorus concentrations by year and month at continuous water-quality monitoring sites in Johnson County, Kansas, 2003-11

20. Graphs showing annual streamflow volume, total nitrogen, and total phosphorus loads originating from wastewater treatment facility discharges compared to total loads in Blue River and Indian Creek, Johnson County, Kansas, 2005-11.

21. Box plots showing computed hourly Escherichia coli bacteria densities by year and month at continuous water-quality monitoring sites in Johnson County, Kansas, 2003-11

22. Graph showing computed hourly Escherichia coli bacteria density and probability of exceeding primary and secondary contact criteria at the Indian Creek monitoring site during 2008 and Kill Creek monitoring site during 2006, Johnson County, Kansas

23. Graph showing annual fecal indicator bacteria loads originating from wastewater treatment facility (discharges compared to total loads in Blue River and Indian Creek, Johnson County, Kansas, 2005-11. 


\section{Tables}

1. Continuous in-stream monitoring sites, watershed areas, and land-use percentages in Johnson County, Kansas, 2003-11 ....................................................5

2. Basin-weighted average rainfall for Blue River, Cedar Creek, Indian Creek, Kill Creek, and Mill Creek in Johnson County, Kansas, 2003-11.

3. Annual summary statistics of hourly measured data for streamflow, $\mathrm{pH}$, water temperature, dissolved oxygen, specific conductance, and turbidity, and of hourly computed data for chloride, suspended sediment, total nitrogen, total phosphorus, and Escherichia coli bacteria at continuous monitoring sites in Johnson County, Kansas, 2003-11...

4. Annual streamflow volume, and annual streamflow yield at monitoring sites in Johnson County, Kansas, 2003-11

5. Annual loads and yields using hourly computed data for chloride, suspended-sediment concentration, total nitrogen, total phosphorus, and Escherichia coli bacteria.

6. Annual streamflow-weighted concentrations for chloride, suspended sediment, total nitrogen, total phosphorus, and Escherichia coli bacteria, 2003-11 


\section{Conversion Factors}

Inch/Pound to SI

\begin{tabular}{|c|c|c|}
\hline Multiply & By & To obtain \\
\hline \multicolumn{3}{|c|}{ Length } \\
\hline inch (in.) & 2.54 & centimeter $(\mathrm{cm})$ \\
\hline inch (in.) & 25.4 & millimeter $(\mathrm{mm})$ \\
\hline foot $(\mathrm{ft})$ & 0.3048 & meter $(\mathrm{m})$ \\
\hline mile (mi) & 1.609 & kilometer (km) \\
\hline \multicolumn{3}{|c|}{ Area } \\
\hline square mile $\left(\mathrm{mi}^{2}\right)$ & 259.0 & hectare (ha) \\
\hline square mile $\left(\mathrm{mi}^{2}\right)$ & 2.590 & square kilometer $\left(\mathrm{km}^{2}\right)$ \\
\hline \multicolumn{3}{|c|}{ Volume } \\
\hline cubic foot $\left(\mathrm{ft}^{3}\right)$ & 28.32 & cubic decimeter $\left(\mathrm{dm}^{3}\right)$ \\
\hline cubic foot $\left(\mathrm{ft}^{3}\right)$ & 0.02832 & cubic meter $\left(\mathrm{m}^{3}\right)$ \\
\hline \multicolumn{3}{|c|}{ Flow rate } \\
\hline cubic foot per second $\left(\mathrm{ft}^{3} / \mathrm{s}\right)$ & 0.02832 & cubic meter per second $\left(\mathrm{m}^{3} / \mathrm{s}\right)$ \\
\hline $\begin{array}{l}\text { million gallons per day per } \\
\text { square mile }\left[(\mathrm{Mgal} / \mathrm{d}) / \mathrm{mi}^{2}\right]\end{array}$ & 1,461 & $\begin{array}{l}\text { cubic meter per day per square } \\
\text { kilometer }\left[\left(\mathrm{m}^{3} / \mathrm{d}\right) / \mathrm{km}^{2}\right]\end{array}$ \\
\hline
\end{tabular}

Temperature in degrees Celsius $\left({ }^{\circ} \mathrm{C}\right)$ may be converted to degrees Fahrenheit $\left({ }^{\circ} \mathrm{F}\right)$ as follows:

${ }^{\circ} \mathrm{F}=\left(1.8 x^{\circ} \mathrm{C}\right)+32$

Temperature in degrees Fahrenheit $\left({ }^{\circ} \mathrm{F}\right)$ may be converted to degrees Celsius $\left({ }^{\circ} \mathrm{C}\right)$ as follows:

${ }^{\circ} \mathrm{C}=\left({ }^{\circ} \mathrm{F}-32\right) / 1.8$

Specific conductance is given in microsiemens per centimeter at 25 degrees Celsius $(\mu \mathrm{S} / \mathrm{cm}$ at $\left.25^{\circ} \mathrm{C}\right)$.

Concentrations of chemical constituents in water are given either in milligrams per liter (mg/L) or micrograms per liter $(\mu \mathrm{g} / \mathrm{L})$. 


\title{
Water-Quality Variability and Constituent Transport in Streams of Johnson County, Kansas, Using Continuous Monitoring and Regression Models, 2003-11
}

\author{
By Teresa Rasmussen and Jackline Gatotho
}

\section{Abstract}

The population of Johnson County, Kansas increased by about 24 percent between 2000 and 2012, making it one of the most rapidly developing areas of Kansas. The U.S. Geological Survey, in cooperation with the Johnson County Stormwater Management Program, began a comprehensive study of Johnson County streams in 2002 to evaluate and monitor changes in stream quality. The purpose of this report is to describe water-quality variability and constituent transport for streams representing the five largest watersheds in Johnson County, Kansas during 2003 through 2011. The watersheds ranged in urban development from 98.3 percent urban (Indian Creek) to 16.7 percent urban (Kill Creek). Water-quality conditions are quantified among the watersheds of similar size (50.1 square miles to 65.7 square miles) using continuous, in-stream measurements, and using regression models developed from continuous and discrete data. These data are used to quantify variability in concentrations and loads during changing streamflow and seasonal conditions, describe differences among sites, and assess water quality relative to water-quality standards and stream management goals.

Water quality varied relative to streamflow conditions, urbanization in the upstream watershed, and contributions from wastewater treatment facilities and storm runoff. Generally, as percent impervious surface (a measure of urbanization) increased, streamflow yield increased. Water temperature of Indian Creek, the most urban site which is also downstream from wastewater facility discharges, was higher than the other sites about 50 percent of the time, particularly during winter months. Dissolved oxygen concentrations were less than the Kansas Department of Health and Environment minimum criterion of 5 milligrams per liter about 15 percent of the time at the Indian Creek site. Dissolved oxygen concentrations were less than the criterion about 10 percent of the time at the rural Blue River and Kill Creek sites, and less than 5 percent of the time at the other sites. Low dissolved oxygen at all sites generally coincided with lowest streamflow and warmer water temperatures. Hourly dissolved oxygen concentrations less than 5 milligrams per liter were measured at all sites every year, indicating that even under normal climate conditions in non-urban watersheds such as Kill Creek, dissolved oxygen concentrations may not meet State aquatic-life criterion.

Specific conductance was nearly always highest in Indian and Mill Creeks, which were the most urban streams with the largest upstream discharges from wastewater treatment facilities. The largest chloride concentrations and variability were recorded at urban sites and during winter. Each winter during the study period, chloride concentrations in the most urban site, Indian Creek, exceeded the U.S. Environmental Protection Agency-recommended criterion of 230 milligrams per liter for at least 10 consecutive days.

The U.S. Environmental Protection Agency-recommended ecoregion criterion for turbidity was exceeded 30 (Indian Creek) to 50 (Blue River) percent of the time. The highest average annual streamflow-weighted suspendedsediment concentration during the study period was in Mill Creek, which has undergone rapid development that likely contributed to higher sediment concentrations. One of the largest suspended-sediment load events in Indian Creek was recorded in early May 2007 when about 25 percent of the total annual sediment load was transported during a period of about 2.25 days. A simultaneous load event was recorded in Kill Creek, when about 75 percent of the total annual sediment load was transported. Sediment yields generally increased as percent impervious surface increased.

Computed hourly total nitrogen and total phosphorus concentrations and yields and streamflow-weighted concentrations generally were largest in Indian and Mill Creeks. Annual percent contribution of total nitrogen in the Blue River from wastewater treatment facility discharges ranged from 19 percent in 2010 to 60 percent in 2006. Annual percent contribution of total nitrogen in Indian Creek from wastewater treatment facility discharges ranged from 35 percent in 2010 to 93 percent in 2006. The largest percent nutrient contributions from wastewater discharges coincided with the smallest annual precipitation and streamflow volume, resulting in less contribution originating from runoff. 
Fecal indicator bacteria Escherichia coli density at the urban Indian Creek site was usually the largest of the five monitoring sites, with an annual median density that consistently exceeded the State primary contact criterion value but was less than the secondary contact criterion. Less than 1 percent of the total annual bacteria load in the Blue River and Indian Creek originated from wastewater discharges, except during 2006 when about 6 percent of the Indian Creek load originated from wastewater.

Continuous water-quality monitoring provides a foundation for comprehensive evaluation and understanding of variability and loading characteristics in streams in Johnson County. Because several directly measured parameters are strongly correlated with particular constituents of interest, regression models provide a valuable tool for evaluating variability and loading on the basis of computed continuous data. Continuous data are particularly useful for characterizing nonpoint-source contributions from stormwater runoff. Transmission of continuous data in real-time makes it possible to rapidly detect and respond to potential environmental concerns. As monitoring technologies continue to improve, so does the ability to monitor additional constituents of interest, with smaller measurement error, and at lower operational cost. Continuous water-quality data including model information and computed concentrations and loads during the study period are available at http://nrtwq.usgs.gov/ks/.

\section{Introduction}

Johnson County is located in a rapidly developing area of northeastern Kansas. The population of Johnson County increased by about 24 percent between 2000 and 2012, from about 452,000 people to about 560,000 people (U.S. Census Bureau, 2012). With a population in 2011 of about 553,000 people (U.S. Census Bureau, 2012) and land area of 477 square miles $\left(\mathrm{mi}^{2}\right)$, it also has the highest density of people compared to other Kansas counties, with about 1,170 persons per square mile. Urban development generally affects streams by altering hydrology, geomorphology, water chemistry, ecosystem processes, and aquatic communities. Urban streams can have increased concentrations and numbers of contaminants including metals, nutrients, dissolved solids, toxic organic compounds, and pathogens (Brown and others, 2009).

Balancing development with preservation of natural space has long been a priority for County leaders (Johnson County Park and Recreation District, 2001). Residents recognized the value of preserving stream systems when, in 1986, voters approved a one-half mill levy to establish a streamway park system. Through funds collected from the levy and partnerships with municipalities within the County, the streamway park system steadily increased in size (Johnson County Park and Recreation District, 2001). When completed, park land and trails are expected to extend along all of the
County's major streams with a minimum average width of about 400 feet, connecting major park facilities, expanding recreational opportunities, and providing flood protection, stormwater, and wildlife benefits (Johnson County Park and Recreation District, 2001). In addition to approving a levy for streamway parks, during the early 1990s Johnson County adopted a 1/10-cent sales tax to fund stormwater management projects. The mission of the Stormwater Management Program is to provide financial and technical services that assist in protecting human lives and property, conserving natural resources, and promoting appropriate use of stream corridors (Johnson County Public Works and Infrastructure, 2013).

Protection of water resources also has been a concern for Federal and State agencies. Since 1972 with the passage of the Federal Clean Water Act, a number of programs have been established nationwide to improve and protect water quality. The Kansas Department of Health and Environment (KDHE) has listed several Johnson County streams and lakes as impaired waterways, and total maximum daily loads (TMDLs) have been established to meet designated water body uses (Kansas Department of Health and Environment, 2012). Most impairments identified in Johnson County by KDHE are related to excessive nutrients, sediment, and fecal indicator bacteria. The National Pollutant Discharge Elimination System (NPDES), which affects most municipalities in the County, requires that best management practices (BMPs) be established to control stormwater runoff (Kansas Department of Health and Environment, 2012). Streams also are subject to requirements such as State water-quality standards, nutrient reduction plans, point-source discharge conditions, and other recommended criteria and guidelines (Kansas Department of Health and Environment, 2012). Routine monitoring of stream quality is a necessary component of these water-quality protection programs to characterize stream conditions, understand factors contributing to impairments, determine the most effective management strategies, and document changes over time.

Biological communities respond to changes in streamflow and physical and chemical water-quality characteristics. Aquatic-life-support standards are common benchmarks used to evaluate stream health. Water-quality conditions described by continuous data can have a direct and negative effect on algae, invertebrate, and fish communities. In an assessment of stream biological conditions in Johnson County, Rasmussen and others (2012) determined significant correlations between increasing specific conductance, sediment, and nutrient concentrations and decreasing health of invertebrate communities. Alterations in streamflow also were correlated with declining biological stream health. These results are consistent with national studies (Coles and others, 2012).

The U.S. Geological Survey (USGS), in cooperation with the Johnson County Stormwater Management Program, began a comprehensive study of Johnson County streams in 2002. Previous reports published as part of that study have described water quality of streams throughout the County during baseflow conditions (Lee and others, 2005), biological conditions in streams (Poulton and others, 2007), and relations between 
biological conditions and environmental factors (Rasmussen and others, 2009). In addition, continuous water-quality data and discrete sample data were used to develop regression models and estimate water-quality concentrations, loads, and yields in the County's five largest watersheds during 2 years of monitoring (Rasmussen and others, 2008). This report describes results from continuous monitoring of water quality during the entire monitoring period from 2003 through 2011.

The use of in-stream monitors for collecting continuous water-quality data has become an increasingly important tool for evaluating water quality. Continuous data capture changing conditions that often are missed with conventional sample collection methods. The high-frequency data provide a more thorough characterization of water quality as a basis for managing resource priorities. Ongoing improvements in in-situ sensing technologies continue to make monitors more reliable and operation more affordable. Collection of continuous data is becoming more common in municipal, industrial, State, and Federal monitoring programs for understanding stream processes and factors affecting them, documenting changing conditions, and in making comparisons to regulatory criteria (Glasgow, 2004; Rasmussen and others, 2008). The continuous data described in this report are unique because the study area includes five watersheds of similar size within the same geographical area but with different land uses and levels of urban development.

\section{Purpose and Scope}

The purpose of this report is to describe water-quality variability and constituent transport in streams of Johnson County, Kansas during 2003 through 2011. Water quality is described using continuous in-stream and computed measurements for five sites representing the largest watersheds in Johnson County and covering about 75 percent of the County's land surface. Streamflow, $\mathrm{pH}$, water temperature, specific conductance, and turbidity were measured in-stream. Continuous concentrations of chloride, suspended sediment, nutrients (total nitrogen and total phosphorus), and fecal indicator bacteria (primarily Escherichia coli) were computed using regression models previously developed from continuous data in conjunction with discrete water samples. Continuous daily, monthly, seasonal, and annual loads and yields were calculated using computed concentrations and streamflow. Differences in water quality are evaluated relative to watershed characteristics including hydrologic conditions, drainage areas, urban and rural land use, point sources (primarily wastewater discharges) and nonpoint sources (stormwater runoff), and water-quality standards.

The results are important for understanding variability in concentrations and loads during changing streamflow and seasonal conditions, and to describe differences among sites. In addition, the information can be used to assess water quality relative to TMDLs, NPDES requirements, water-quality standards, BMPs, and stream management goals. This report provides information that is important in decision-making related to stream-quality regulations and management. As urban development continues in the study area, the information will be important as a basis for comparison in future water-quality assessments.

\section{Description of Study Area}

Johnson County, Kansas covers $477 \mathrm{mi}^{2}$ of land in northeastern Kansas (U.S. Census Bureau, 2012). It includes the southwestern part of the Kansas City metropolitan area. About 74 percent of the County is included among the five largest watersheds, which are the focus of this report (fig. 1). The watersheds ranged in size from $50.1 \mathrm{mi}^{2}$ (Kill Creek) to $65.7 \mathrm{mi}^{2}$ (Blue River, table 1). The largest percentage of urban land use occurs in the Indian Creek watershed (98.3 percent, table 1), located in the northeastern part of the County. The smallest percentage of urban land use occurs in the Kill Creek watershed (16.7 percent, table 1), located in the western part of the County. Average annual precipitation in the study area ranges from 38 to 40 inches (U.S. Department of Agriculture, 2007). Twelve municipal wastewater-treatment facilities (WWTFs) were located in Johnson County in 2010, 8 of which had a design discharge capacity of more than 1 million gallons per day (Mgal/d, fig. 1). The largest wastewater discharges occur in the Indian Creek watershed where two WWTFs with a combined design flow capacity of $22 \mathrm{Mgal} / \mathrm{d}$ discharge upstream from the monitoring site. In the Blue River watershed, a WWTF discharge (with a design flow capacity of $3 \mathrm{Mgal} / \mathrm{d}$ until 2007 when facility upgrades increased discharge capacity to $10.5 \mathrm{Mgal} / \mathrm{d}$ ) occurs just downstream from the monitoring site. WWTFs on Cedar, Kill, and Mill Creeks have design capacities ranging from 2.5 to $3.2 \mathrm{Mgal} / \mathrm{d}$, and are located 6 to 13 miles (mi.) upstream from monitoring sites.

Designated uses for streams in Johnson County include support of aquatic life, contact recreation, drinking-water supply, food procurement, groundwater recharge, irrigation, industrial use, and livestock watering (Kansas Department of Health and Environment, 2012).

\section{Previous Studies}

Johnson County stream quality has been the subject of several previous reports. Lee and others (2005) determined that during base-flow conditions, discharge from WWTFs comprised at least 50 percent of the total streamflow at the farthest downstream sites in six of seven watersheds, including the five watersheds evaluated in this report. Also during base-flow, nutrients, dissolved solids, organic wastewater compounds, and pharmaceutical compounds generally were found in highest concentrations at sites at, or immediately downstream from, WWTFs.

Biological conditions generally reflected a gradient in the degree of human disturbance upstream from sites with urban sites being most disturbed (Poulton and others, 2007; 


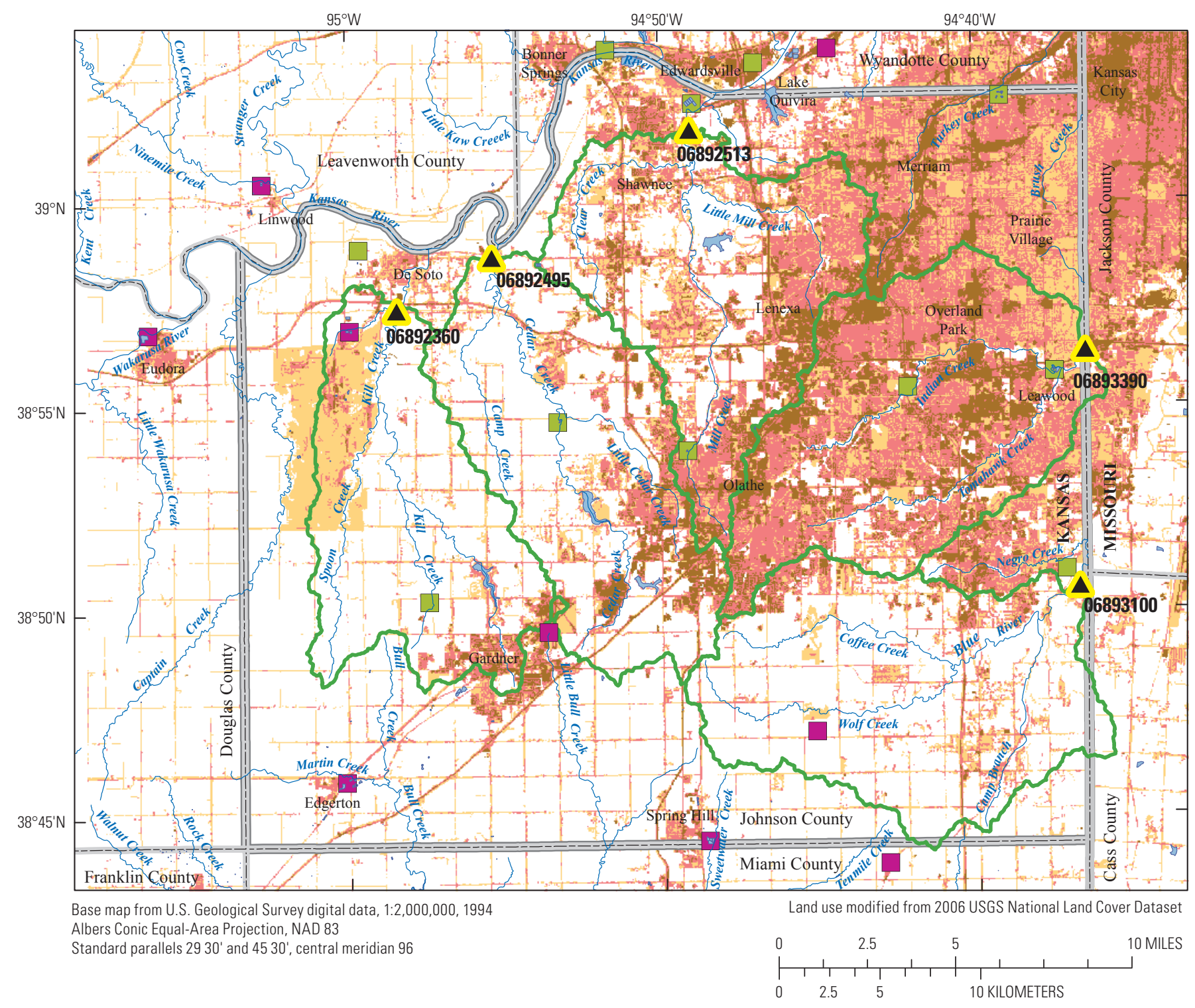

EXPLANATION

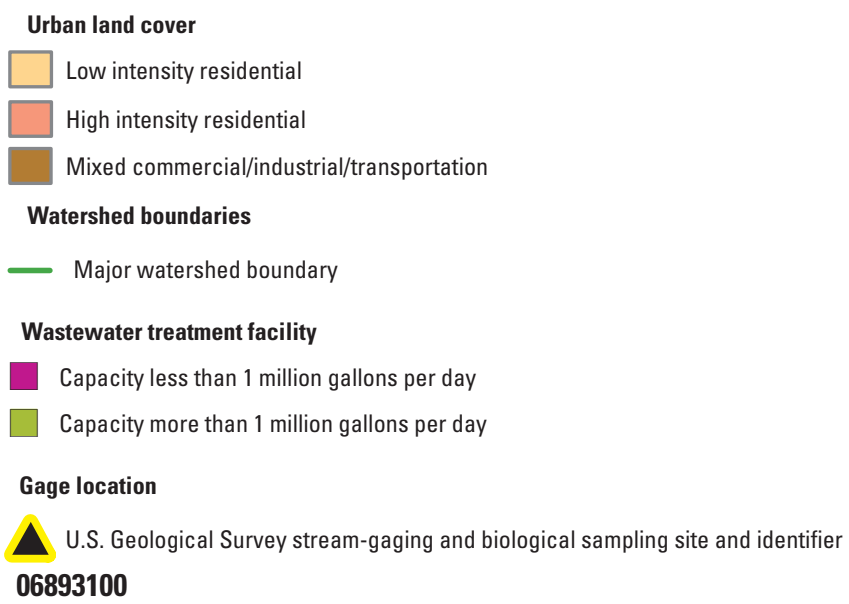

Figure 1. Location of monitoring sites, watershed boundaries, and land use, Johnson County, Kansas. 


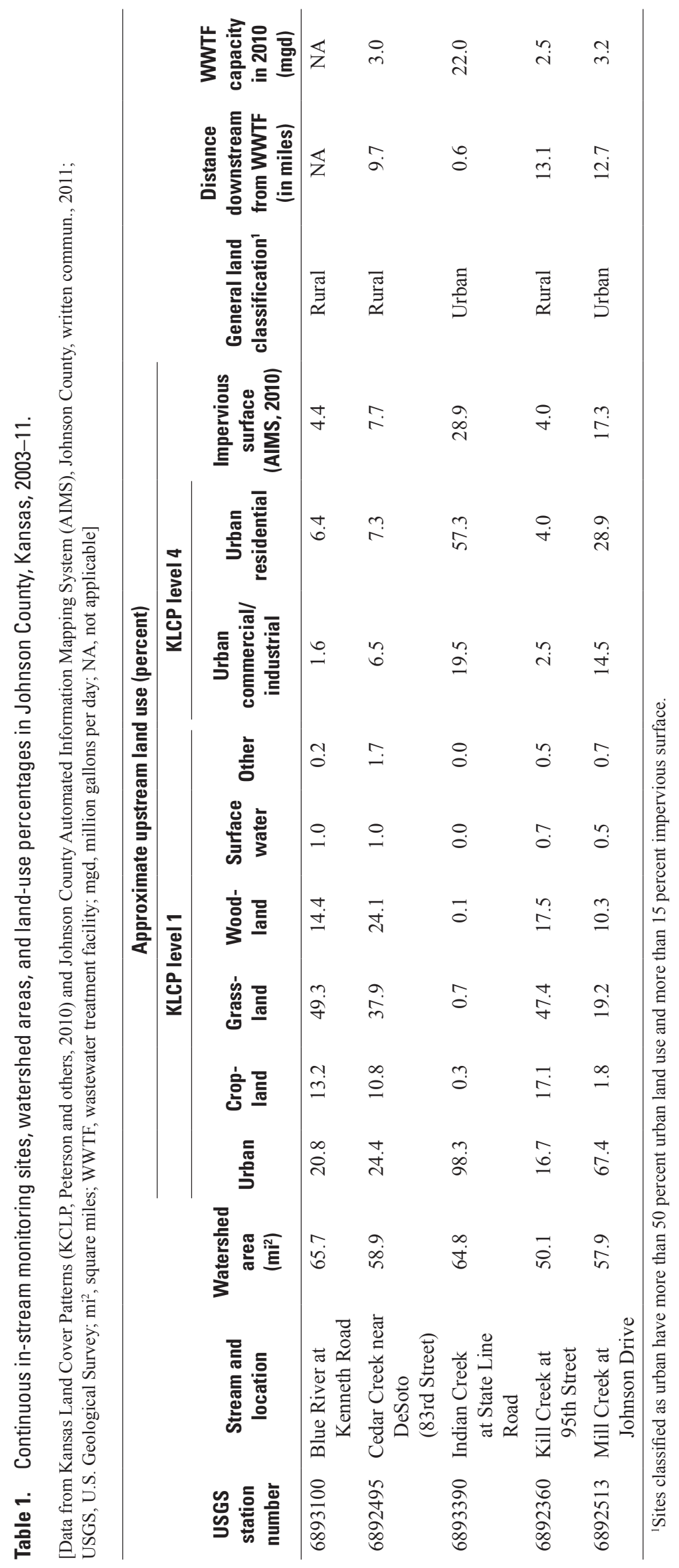


Rasmussen and others, 2009a, 2012). Environmental factors that most strongly correlated with stream biological conditions included amount of upstream urbanization, specific conductance of stream water, concentration of polycyclic aromatic hydrocarbons (PAHs) in streambed sediment, and habitat variables related to riparian buffer condition and sediment deposition (Rasmussen and others, 2009a, 2012). No sites consistently meet KDHE criteria for full support of aquatic life (Rasmussen and others, 2009a, 2012).

Chemical concentrations, loads, and yields in five principal Johnson County streams were described using data and statistical models based on continuous water-quality monitoring during 2002-11 (Rasmussen and others, 2012). Concentrations of suspended sediment, chloride, and fecal-indicator bacteria generally were higher in more urban watersheds than in nonurban watersheds and were substantially higher during periods of increased streamflow. At least 90 percent of the total suspended-sediment load during 2005-06 in all five watersheds was transported in less than 2 percent of the time during periods of increased streamflow. Construction activities were determined to be the primary contributor of excess sediment to Mill Creek and its tributaries (Lee and others, 2009).

A study of the effects of wastewater discharge on biological conditions in the upper Blue River in Johnson County (Graham and others, 2010) indicated that the largest differences between sites upstream and downstream from wastewater discharge were in nutrient concentrations, which were significantly higher downstream, particularly during normal and below-normal streamflows. Aquatic-life-support scores were significantly lower downstream, and ecosystem functional health was mildly impaired downstream from the wastewater discharge. Functional health was evaluated on the basis of primary production and community respiration, computed using continuous water-quality monitoring data.

Assessments of water quality in Kansas City, Missouri, based on data collected during 1998 through 2007 included some upstream sites in Johnson County (Wilkison and others, 2002, 2006, 2009). Primary sources of nutrients were nonpoint-source runoff and WWTFs, with relative contributions dependent upon annual precipitation.

\section{Methods}

Methods for collection of continuous streamflow and water-quality data, collection of discrete water samples, and development of regression models is described in detail by Rasmussen and others (2008). This section contains a summary of those methods.

\section{Data Collection and Laboratory Analyses}

Streamflow-gaging stations and continuous water-quality monitors (fig. 2) were installed at five stream sites in Johnson County, Kansas (fig. 1, table 1). Monitoring sites were located as far downstream as possible within each of the five watersheds to be representative of most of each drainage area. Monitors operated from January 2003 through December 2007 in Cedar Creek (USGS station 06892495), from January 2003 through December 2008 in Mill Creek (station 06892513), from January 2004 through December 2007 in Kill Creek (station 06892360), and from January 2004 through December 2011 in the Blue River (station 06893100) and Indian Creek (station 06893390). Each site was equipped with a water-quality monitor that provided continuous (at least every 15 minutes) in-stream measurements of specific conductance, $\mathrm{pH}$, water temperature, turbidity (YSI model 6136), and dissolved oxygen (DO). Hourly average values were used for data analysis and interpretation in this report. These data are available in real-time on USGS Web pages (http://nrtwq.usgs.gov/ks/ and http://waterdata.usgs.gov/ks/nwis/current/?type $=q w$ ). Streamflow was measured using methods presented in Turnipseed and others (2010). Monitor maintenance and data reporting followed standard procedures described in Wagner and others (2006). Each monitor was located within the stream cross-section to be representative of conditions across the width of the stream, which was verified using cross-section measurements during different streamflow and seasonal conditions (Rasmussen and others, 2008). By placing monitors in the deepest available flowing water, they remained deployed year-round including during winter when ice can develop on the water surface. Quality of data during the study period generally was good or excellent according to guidelines described by Wagner and others (2006).

Most annual datasets for in-stream measurements were 95 to 100 percent complete with a few exceptions. Monitors were installed at all sites in mid-February of the first year monitored in 2003 or 2004 except Mill Creek, which started on January 1, 2003; therefore, during the first monitoring year at the other four sites, annual record completion could not exceed 85 percent. Records for the remaining years were at least 90 percent complete except dissolved oxygen at Kill Creek in 2007, which was 88 percent complete, and pH, which was 73 percent complete at Mill Creek in 2007, and 80 to 90 percent complete at the Blue River, Cedar Creek, or Indian Creek sites during either 2006 or 2007. Missing data were not estimated. Missing data usually occurred during stable base-flow conditions rather than during large runoff events when conditions change rapidly. A typical example of missing turbidity data was during June 21-23, 2008 when streamflow was lower and turbidity was stable (fig. 3). The most important example of missing data likely is when the turbidity sensor at Indian Creek malfunctioned during the second largest streamflow event of the monitoring period resulting in loss of data throughout a 38-hour period during July 30-31, 2008 (fig. 3).

In addition to continuous monitoring, discrete water samples were manually collected from each site according to either the equal depth integrated (EDI) method or the equal width integrated (EWI) method described by U.S. Geological Survey (2006) or occasionally using automated samplers. Samples collected using autosamplers were evaluated for 

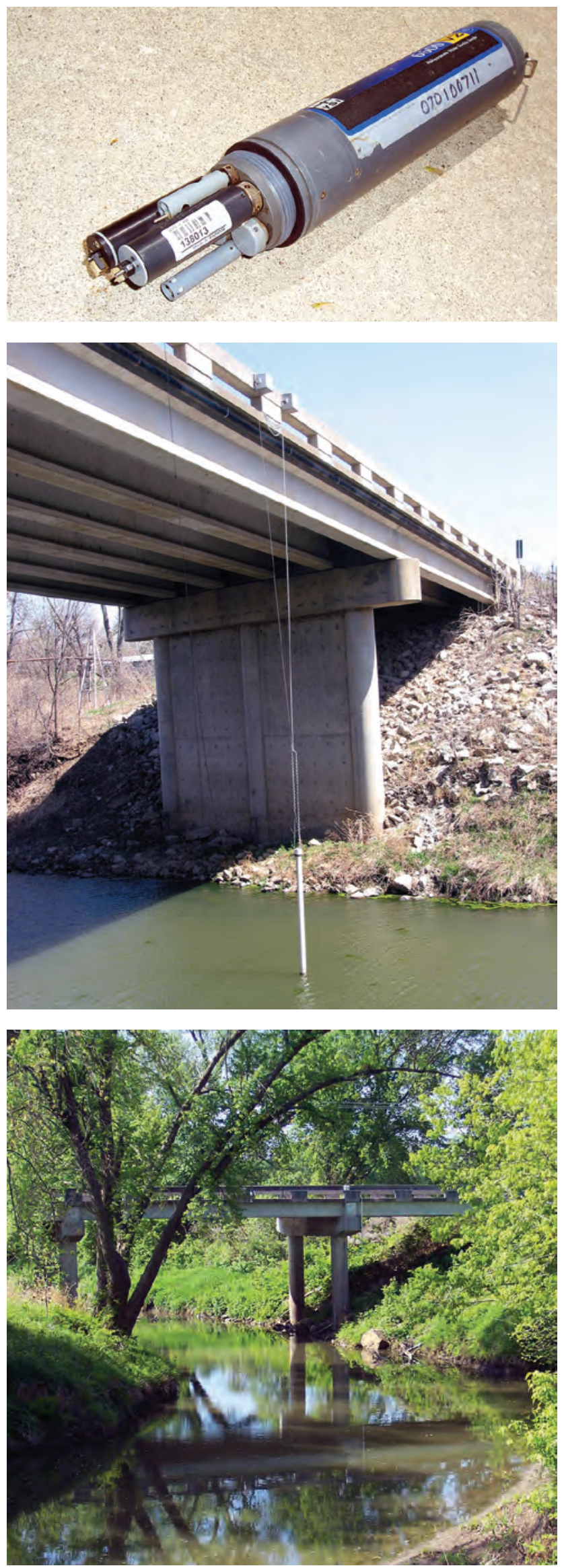
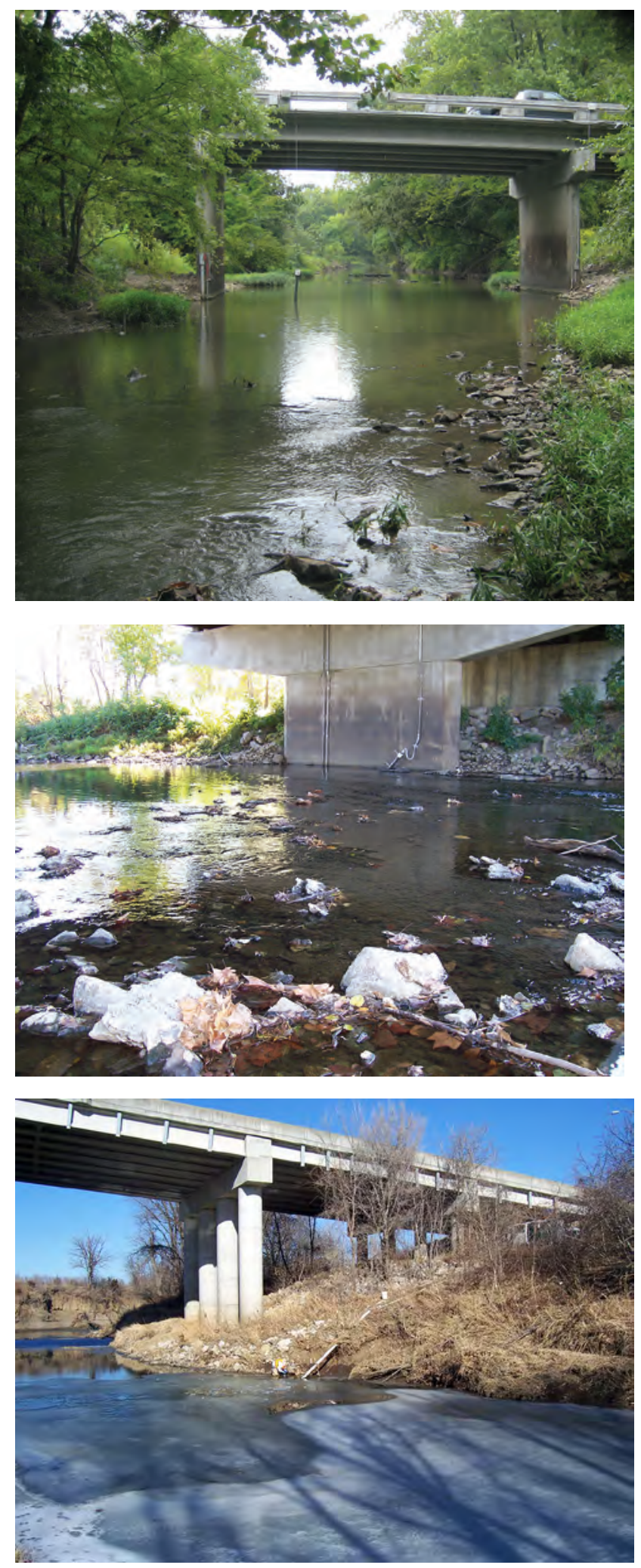

Figure 2. Photographs showing $A$, continuous water-quality monitor, and monitoring sites and equipment in $B$, the Blue River; $C$, Cedar Creek; $D$, Indian Creek; $E$, Kill Creek; and F, Mill Creek, in Johnson County, Kansas. 


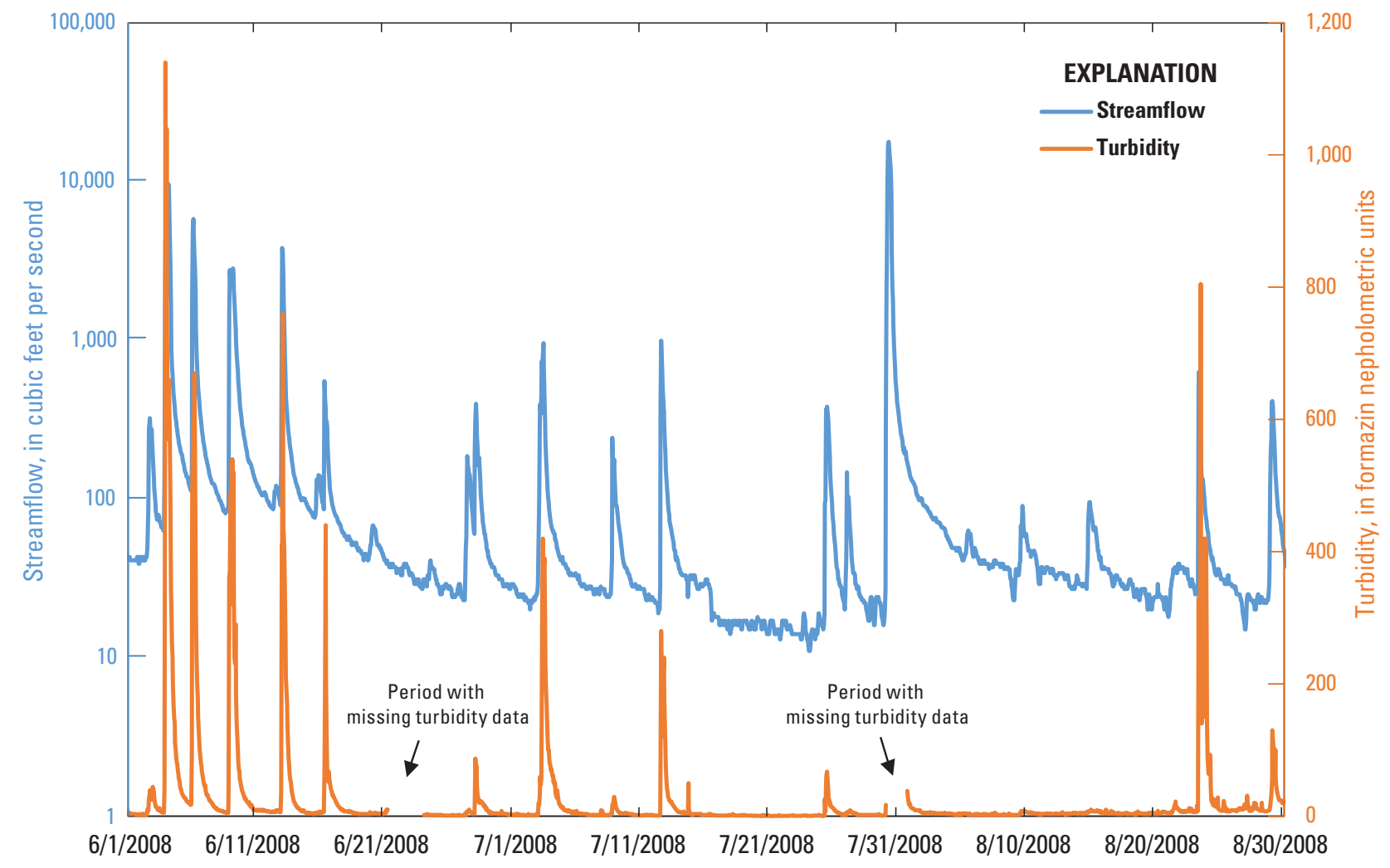

Figure 3. Hourly streamflow and turbidity at the Indian Creek monitoring site, in Johnson County, Kansas, June through August 2008.

variability and determined to not have consistent bias resulting from placement or operation of autosampling equipment. Sample collection also followed methods described by Edwards and Glysson (1999) for collecting representative samples to be analyzed for suspended sediment and other water-quality constituents. At each site, 18 to 28 samples were collected between October 2002 and January 2006 and timed to evenly represent the range in conditions that occurred at each site. Samples represented about 90 percent of the range in streamflow conditions.

Samples were analyzed for major ions, suspended sediment, nutrients, and fecal indicator bacteria. Major ions and nutrients were analyzed at the Johnson County Environmental Laboratory in Johnson County, Kansas, according to standard methods (American Public Health Association and others, 1995). Replicate samples for major ions and nutrients were analyzed by the USGS National Water-Quality Laboratory (NWQL) in Denver, Colorado, according to methods presented in Fishman and Friedman (1989), Faires (1993), and Fishman (1993). Suspended-sediment samples were analyzed by the USGS Sediment Laboratory in Iowa City, Iowa, according to methods presented in Guy (1969). Analysis of indicator bacteria ( $E$. coli, fecal coliform, and enterococci) was done at the USGS laboratory in Lawrence, Kansas. Results from blank and replicate sample analysis indicated that the relative percent difference between replicate pairs was less than 10 percent for all constituents with the exception of some nutrient species, which have higher relative percent differences at low concentrations, and indicator bacteria, which can be about 30 percent because of higher uncertainties associated with the analysis methods. Additional details can be found in Rasmussen and others (2008).

\section{Regression Models and Computation of Concentrations, Loads, and Yields}

Existing models (Rasmussen and others, 2008; Graham and others, 2010) were developed using ordinary least squares (OLS) regression analysis in relating continuous sensor measurements, streamflow, and season to discretely sampled constituent concentrations (Helsel and Hirsch, 2002; Christensen and others, 2000). Uncertainty for each estimate from regression models was calculated using 90-percent prediction intervals (Helsel and Hirsch, 2002). Probabilities of exceeding water-quality standards, recommended criteria, or guidelines of the State of Kansas and USEPA also were calculated (Rasmussen and Ziegler, 2003; Francy and Darner, 2006).

The previously published models (Rasmussen and others, 2008; Graham and others, 2010) were evaluated to determine whether existing models were suitable for computing concentrations for the entire study period through 2011. The previous site-specific models were developed using 18-27 samples per site collected during October 2002 through December 2006 
(Rasmussen and others 2008). Regression models for the Blue River site were updated using additional data collected through March 2009 (Graham and others, 2010). Because additional samples (3-12 samples per site collected during 2007-11) followed similar plotting patterns as samples for existing models, it was determined that the existing models were suitable for computing continuous constituent concentrations. For example, at least 90 percent of the additional samples for chloride, suspended sediment, and E. coli bacteria generally plotted within the 90-percent prediction intervals of the existing models (fig. 4). The models shown in figure 4 have the same single explanatory variable, specific conductance for computing chloride and turbidity for computing suspended-sediment concentration and E. coli bacteria. The prediction interval for a single regression model using data for all sites combined is shown in figure 4 to simplify the figure.

Models for nutrients used multiple and different explanatory variables among sites, that included turbidity, streamflow, and a seasonal variable. Models and best-fit lines for each site are shown in figure 5 for discretely measured nutrients compared to computed nutrients. No significant explanatory variables were determined for total nitrogen or total phosphorus at the Cedar Creek site so that site is not included in nutrient discussions. The Cedar Creek watershed contains more impoundments than most of the other watersheds, which may affect relations between sediment and nutrients. By trapping sediment, impoundments also can trap nutrients that attach to sediment. The best nutrient models, as indicated by high coefficient of determination $\left(R^{2}\right)$ values and other model diagnostics, were for the Blue River and Kill Creek sites, the two least urban watersheds and the two sites with the strongest correlations between suspended-sediment concentration and total nitrogen and phosphorus (Rasmussen and others, 2008). Samples collected from Indian Creek after model development are the most variable. Variability in the Indian Creek regression models for total nitrogen and total phosphorus likely is a result of the effects of WWTFs and changing predominant sources at that site during various streamflow conditions. The Indian Creek models currently (2013) are being updated as part of a separate study evaluating the effects of wastewater treatment facility upgrades on water quality.

Hourly loads were calculated for each constituent by multiplying hourly computed concentrations by hourly streamflow and a conversion factor. Constituent yields from the contributing watershed areas were calculated by dividing total loads by corresponding drainage areas. Loads from WWTFs were calculated from weekly water-quality and outflow data that were provided by Johnson County Wastewater. Annual streamflow-weighted concentrations were calculated by dividing annual load (in tons) by annual streamflow volume (in acre-feet) and multiplying by a unit conversion [x 907.2 kilograms per ton ( $\mathrm{kg} /$ ton) x 1,000,000 milligrams per kilogram) divided by $1,233,482$ liters per acre-feet (L/acre-ft)] to obtain annual streamflow-weighted concentrations in milligrams per liter. Streamflow-weighted concentrations represent the average amount of constituent transported in a given volume of streamflow, and are used to compare conditions among sites and years while taking into account differences in streamflows.

Duration curves are cumulative distribution functions of all measurements (hourly values, in this report) within a specified period of time and are used to compare conditions among sites. The curves show the percentage of time specific conditions were equaled or exceeded, or the frequency of exceedence (Maidment, 1993).

Computed concentrations and loads for sediment, nutrients, and bacteria are affected by missing turbidity data because turbidity is an explanatory variable for those constituents. Summary statistics such as mean, median, and maximum may be biased because of missing turbidity data. Missing turbidity values result in underestimation of annual loads by an unknown amount. Annual loads also are underestimated when in-stream turbidity exceeds the maximum value the sensor is capable of measuring. This maximization occurred rarely (less than 1 percent of the time) but always during runoff events when loads are largest. A noteworthy example of missing turbidity data that affected load computations was Indian Creek during July 2008 when the sensor malfunctioned for a 38-hour period during an event with a peak streamflow of $17,900 \mathrm{ft}^{3} / \mathrm{s}$ (fig. 3). The July 2008 event was the second largest streamflow on record and a 25 -year event, which means it had a streamflow magnitude with a probability of occurring once every 25 years, or a 4 percent chance in any given year (Perry and others, 2004). Cedar Creek also was affected by 36 hours of missing turbidity data in March 2004 when the sensor malfunctioned during the largest streamflow of the year $\left(6,140 \mathrm{ft}^{3} / \mathrm{s}\right.$, a 2 -year event). Five hours of turbidity data were missing from the Blue River site in June 2010 during the largest streamflow of the year $\left(8,490 \mathrm{ft}^{3} / \mathrm{s}\right.$, between a 2-year and 5 -year event). The Blue River turbidity sensor was maximized in May 2004 for a 6-hour period during the largest streamflow on record $\left(10,500 \mathrm{ft}^{3} / \mathrm{s}\right.$, slightly less than a 5 -year event). Mill Creek was not affected by missing data during large streamflow events but was affected in 2004, 2005, 2007, and 2008 when the turbidity sensor was maximized for $2-5$ hours during one or two events annually with peak streamflows ranging from 5,000-10,000 $\mathrm{ft}^{3} / \mathrm{s}$. The 2-year streamflow at Mill Creek is $7,770 \mathrm{ft}^{3} / \mathrm{s}$.

\section{Water-Quality Variability and Constituent Transport}

Continuous data from the five sites are presented in this section for the years that monitors were in operation at each site. Although regression models have been developed for many additional water-quality constituents (Rasmussen and others, 2008), this report is focused on directly measured water-quality parameters and computed chloride, suspended sediment, total nitrogen and total phosphorus, and E. coli bacteria. Examples are provided to illustrate differences among sites during changing seasons, between base flow and 

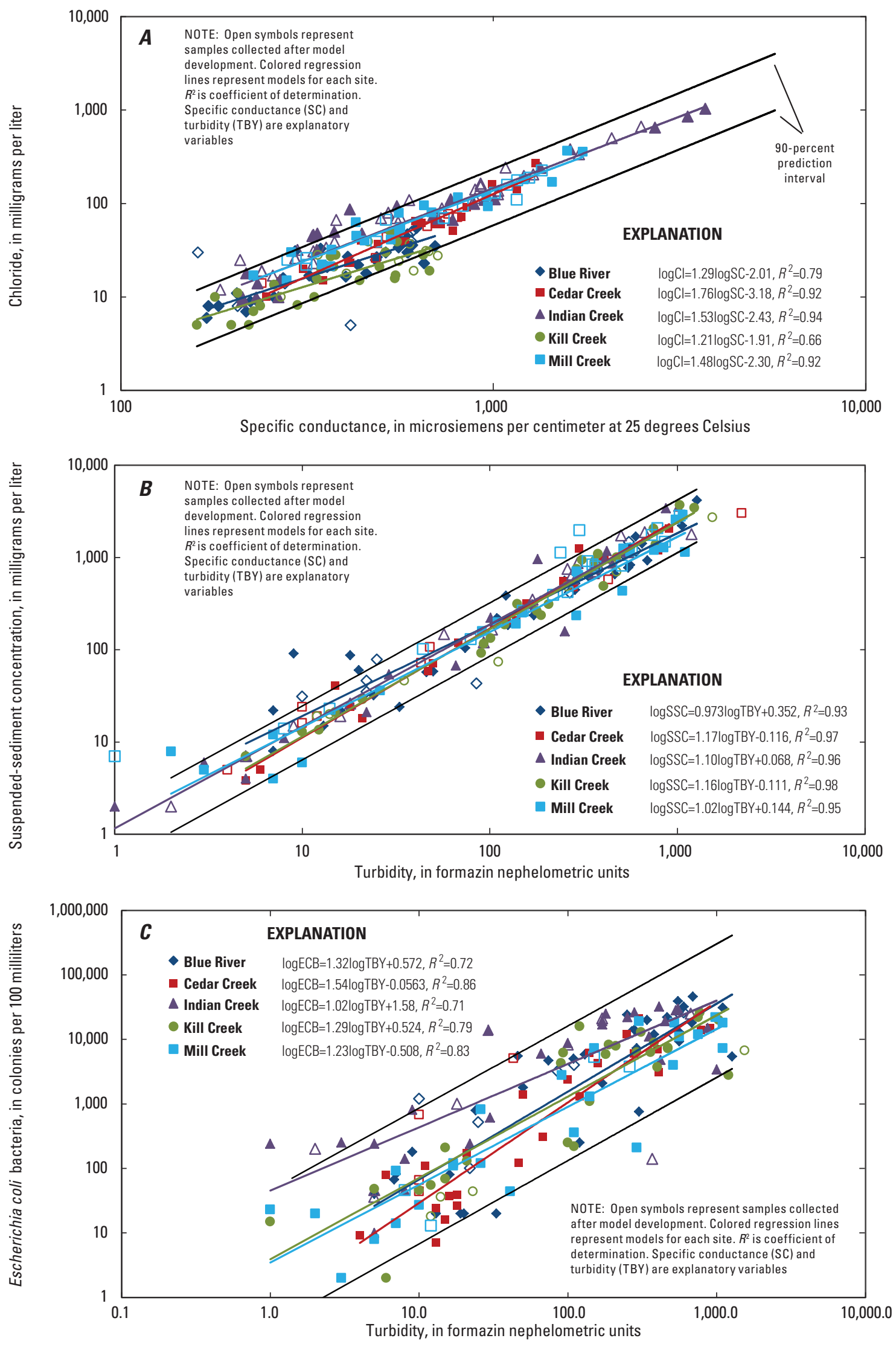

Figure 4. Regression models showing explanatory and response variables, discrete data, and prediction intervals for $A$, chloride (Cl), $B$, suspended sediment (SSC), and $C$, Escherichia coli bacteria (ECB). 


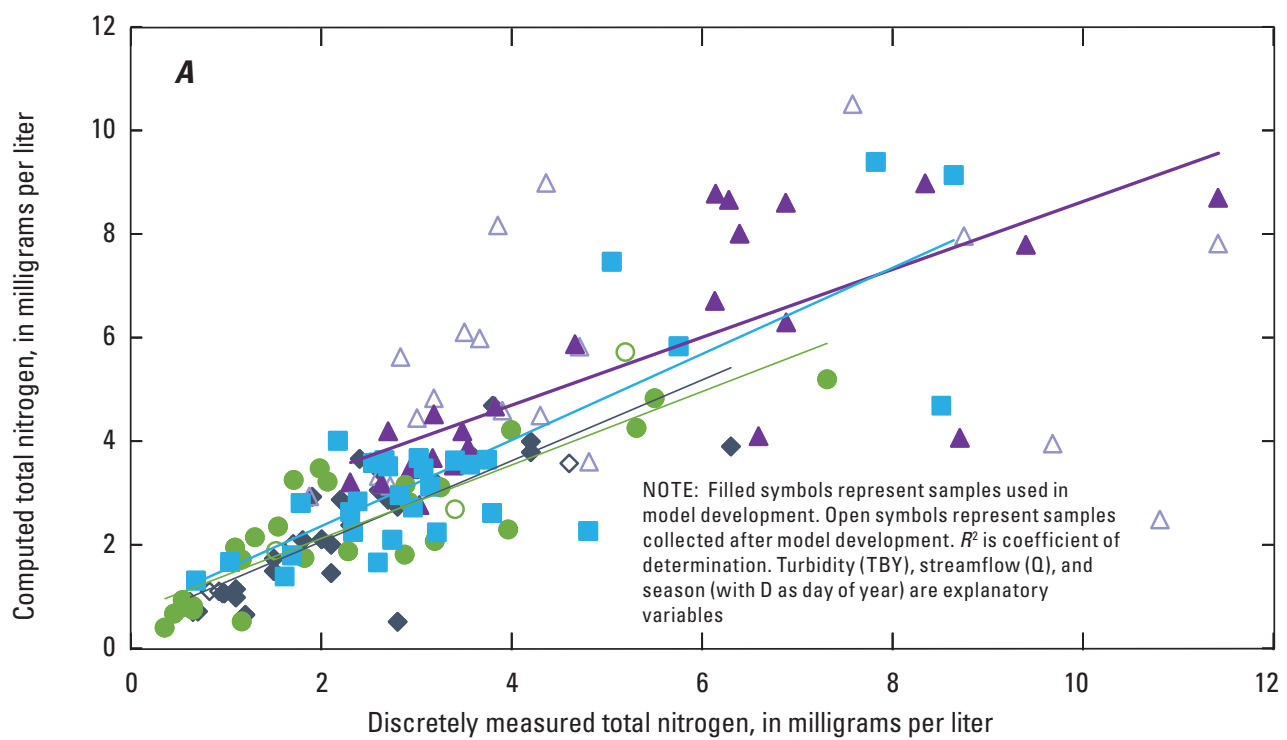

EXPLANATION

- Blue River $\quad \log \mathrm{TN}=0.373 \log \mathrm{TBY}-0.483, R^{2}=0.79$

$\Delta$ Indian Creek $\log \mathrm{T}=-0.173 \log \mathrm{TBY}+0.126 \sin (2 \pi \mathrm{D} / 365)+0.0302 \cos (2 \pi \mathrm{D} / 365)+0.986, R^{2}=0.61$

- Kill Creek $\log \mathrm{TN}=0.423 \log \mathrm{TBY}-0.624, R^{2}=0.76$

Mill Creek $\log \mathrm{TN}=0.0006 \log \mathrm{TBY}+0.0483 \sin (2 \pi \mathrm{D} / 365)+0.220 \cos (2 \pi \mathrm{D} / 365)+0.296, R^{2}=0.61$

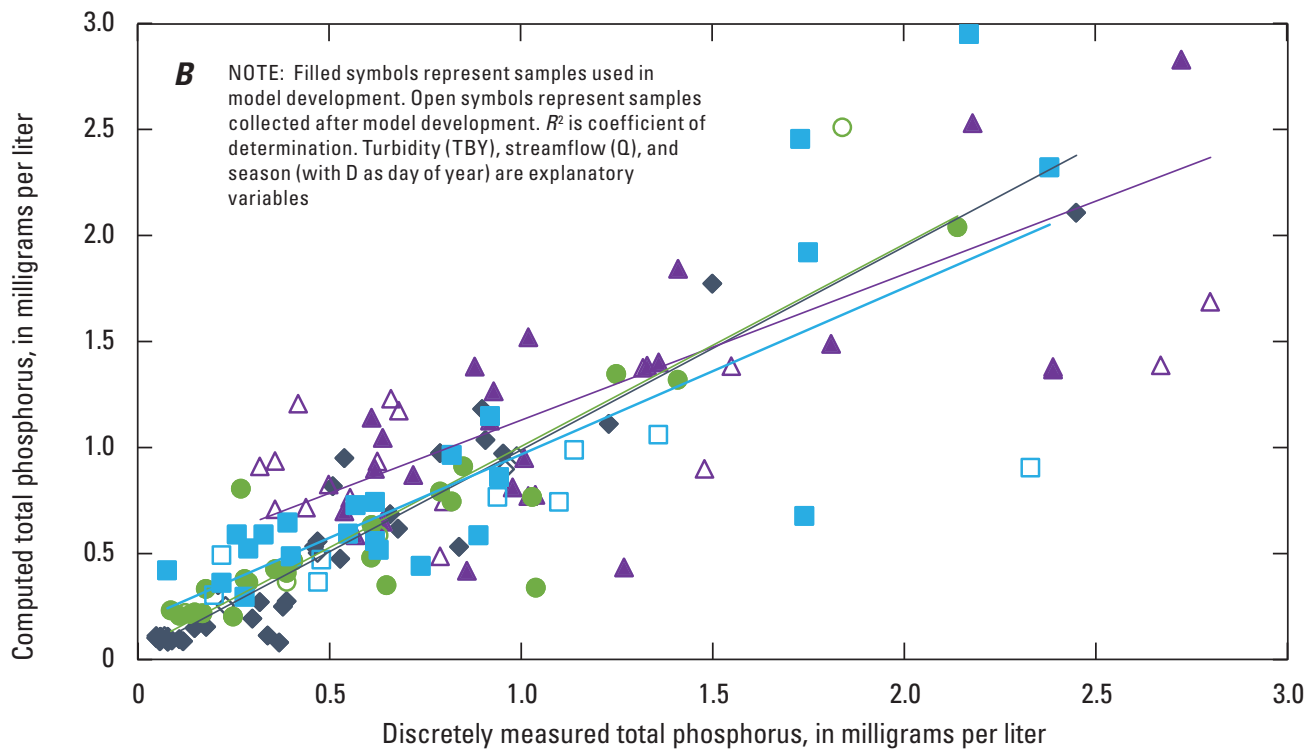

EXPLANATION

\begin{tabular}{|c|c|}
\hline Blue River & $\mathrm{TP}=0.0016 \mathrm{TBY}+0.0754, R^{2}=0.94$ \\
\hline Indian Creek & $\log \mathrm{TP}=-0.299 \log \mathrm{Q}+0.0009 \mathrm{TBY}+0.586, R^{2}=0.62$ \\
\hline & $\mathrm{TP}=0.0015 \mathrm{TBY}+0.199, R^{2}=0.81$ \\
\hline Creek & $\log \mathrm{TP}=0.0008 \mathrm{TBY}+0.0222 \sin (2 \pi \mathrm{D} / 365)+0$. \\
\hline
\end{tabular}

Figure 5. Regression models and best-fit lines for $A$, total nitrogen (TN), and $B$, total phosphorus (TP), showing discretely measured values and computed values. 
stormflow conditions, and between rural and urban streams. Blue River and Indian Creek often are compared because these sites are of similar size, have the longest data record, but differ in the amount of upstream urbanization and the presence of upstream WWTF discharges (table 1). Directly measured data are presented first for streamflow, $\mathrm{pH}$, water temperature, and dissolved oxygen. Specific conductance data are presented, along with computed concentrations, loads, and yields of chloride, which is closely related to specific conductance. Turbidity is then presented, along with computed concentrations, loads, and yields of suspended sediment, which is closely related to turbidity. Finally, computed concentrations, loads, and yields of total nitrogen and total phosphorus are presented, followed by computed densities, loads, and yields of $E$. coli bacteria.

Average annual precipitation in the study area (38 inches) was about normal (41.4 inches, 1981-2010; National Weather Service, 2012) during the study period, and ranged from about 32 inches in 2003 to 46 inches in 2008 (fig. 6). The largest average monthly precipitation during the study period was in June, and the smallest average monthly precipitation was in November, December, and January (fig. 6). Precipitation data presented are from a weather station located centrally within the study area (Olathe Johnson County Executive Airport, National Oceanic and Atmospheric Administration, http://www. nws.noaa.gov/climate/xmacis.php? wfo=eax). However, actual rainfall varied from one watershed to the next within the study area. Basin-weighted average rainfall is provided in table 2 .

\section{Streamflow}

During the study period, peak-discharge frequencies for approximately the 2-year flood (Perry and others, 2004) occurred at least once at each site except Kill Creek. Approximate 5-year floods (Perry and others, 2004) occurred at the Blue River and Indian Creek sites. Two approximate 25-year floods (Perry and others, 2004) occurred in Indian Creek. Peak-discharge frequencies from Perry and others (2004) represent the best available estimates but likely underestimate frequencies in urban areas.

Mean hourly streamflow at the five monitoring sites during the study period ranged from 9.7 cubic feet per second $\left(\mathrm{ft}^{3} / \mathrm{s}\right)$ in 2006 at the Kill Creek site, which drains the smallest watershed $\left(50.1 \mathrm{mi}^{2}\right)$, to $129 \mathrm{ft}^{3} / \mathrm{s}$ in 2008 and 2010 at the Indian Creek site, which drains one of the largest watersheds (64.8 $\mathrm{mi}^{2}$, table 3$)$. Mean daily streamflows during the study period indicated a seasonal pattern with highest streamflows recorded during spring months and lowest streamflows during winter (fig. 7A). Fairly constant flow was maintained in Indian and Mill Creeks during the study period, whereas the Blue River and Kill Creek had periods of near-zero flow (table 3; fig. 7A). Hourly streamflow in Indian Creek was never less than $8.5 \mathrm{ft}^{3} / \mathrm{s}$ (table 3 ) because streamflow is sustained by two upstream WWTF discharges. Hourly streamflow in the Blue River decreased to about $1 \mathrm{ft}^{3} / \mathrm{s}$ or less most years during the fall and reached zero or near zero for brief periods during the fall of 2005, 2006, and 2011 (table 3, fig. 7A). Hourly

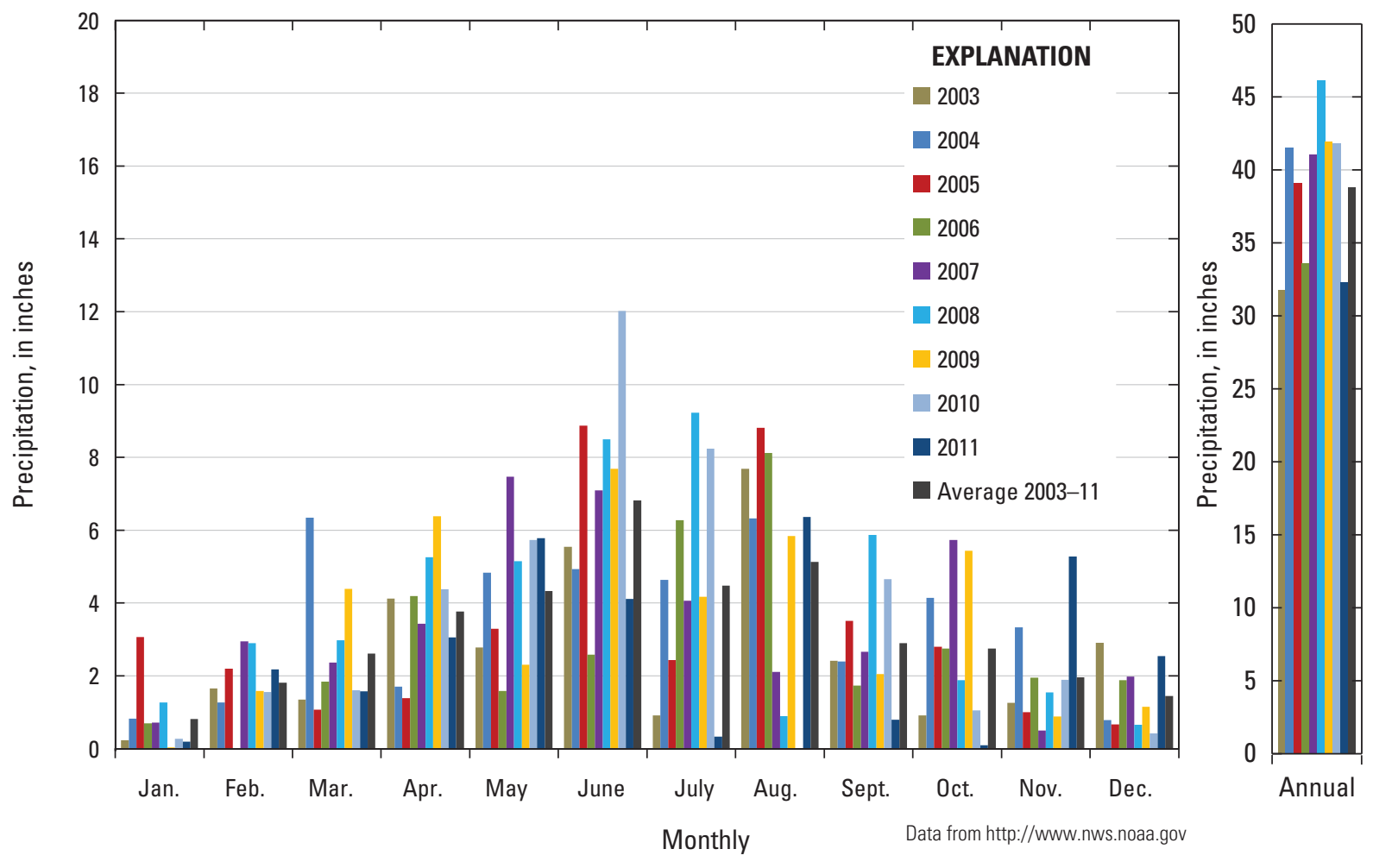

Figure 6. Monthly and annual precipitation in Olathe, Kansas, 2003-11. 
Table 2. Basin-weighted average rainfall (in inches) for Blue River, Cedar Creek, Indian Creek, Kill Creek, and Mill Creek in Johnson County, Kansas, 2003-11 (data from http://stormwatch.com/Rainfall_Data/Rainfall_Totals.aspx).

\begin{tabular}{|c|c|c|c|c|c|c|c|c|c|}
\hline \multirow{2}{*}{ Watershed } & \multicolumn{9}{|c|}{ Year } \\
\hline & 2003 & 2004 & 2005 & 2006 & 2007 & 2008 & 2009 & 2010 & 2011 \\
\hline Blue River & 29.8 & 47.3 & 37.5 & 37.1 & 38.7 & 47.0 & 41.6 & 42.1 & 33.4 \\
\hline Indian Creek & 20.5 & 27.6 & 28.4 & 23.3 & 31.3 & 38.0 & 40.4 & 39.1 & 28.1 \\
\hline Tomahawk Creek & 31.8 & 43.2 & 40.8 & 30.2 & 41.4 & 50.5 & 46.6 & 46.5 & 34.7 \\
\hline Mill Creek & 30.0 & 39.9 & 42.8 & 30.2 & 29.0 & 32.5 & 32.0 & 27.5 & 22.9 \\
\hline Little Mill Creek & 32.1 & 43.0 & 45.8 & 30.5 & 43.2 & 48.1 & 47.8 & 44.9 & 34.8 \\
\hline
\end{tabular}

streamflow duration curves for the period of record when water-quality monitors were operating at each site indicate that streamflow was highest nearly all of the time in Indian Creek and lowest in Kill Creek except during about 5 percent of the time in the low-flow range (greater than 95-percent frequency of exceedence) when Blue River streamflow was lowest (fig. 8A).

All of the monitoring sites except the Blue River are affected by upstream WWTF discharges. The largest (combined design capacity of $22 \mathrm{Mgal} / \mathrm{d}$ ) and nearest (0.6 mi.) discharge is upstream from the Indian Creek site. Streamflow increases about $2 \mathrm{mi}$. downstream from the monitoring site where a WWTF discharges into the Blue River. Daily fluctuations in streamflow often occur downstream from WWTFs because of changes in the wastewater effluent discharge rate. For example, a diel (24-hour cycle) streamflow pattern is evident during base flow at the Mill Creek site (fig. 9, $A 1$ ). In addition, diel streamflow fluctuations can occur because of evapotranspiration in gaining streams or infiltration through the streambed in losing streams (Lundquist and Cayan, 2002).

Urbanization typically increases the volume of runoff and the frequency and magnitude of high streamflows (Leopold, 1968 ) as a result of increased impervious surfaces such as roads and parking lots that are designed to move stormwater runoff quickly to streams. In addition, the duration of high streamflow events usually decreases with increased urbanization. The rapid runoff also reduces infiltration into the ground, which increases total runoff volume. In an analysis of streamflow characteristics at seven stream sites in Johnson County including the five sites described in this report, urban sites were determined to have higher streamflows and increased frequency of streamflow events (Rasmussen and others, 2012). In an example of differences between rural and urban stream sites with comparable drainage areas (table 1) during a typical winter and summer period (fig. 10, $A 1$ and $B 1$ ), the urban Indian Creek site has higher streamflow and larger and more frequent streamflow events than the rural Blue River site. Base flow is not decreased in Indian Creek because flow is sustained by WWTF discharges. Lee and others (2005) determined that WWTF discharge helped sustain flow at each of the sites included in this report except the Blue River.

Indian Creek also had the largest annual streamflow volumes and yields during the study period (table 4). On an annual site-to-site basis, variation in streamflow volume corresponded with variation in annual precipitation. During 2005 when about average rainfall occurred in the study area, streamflow volume in urban Indian Creek (71,700 ac-ft) was about double the volume in the smallest and least urban watershed, Kill Creek (34,800 ac-ft), and 52 percent larger than the volume in the similar-sized but rural watershed, Blue River (47,100 ac-ft, table 4). Streamflow yield in urban Indian Creek was higher than Blue River yield each year, ranging from 27 percent higher in 2004 when the largest annual rainfall volume occurred, to 3.4 times higher in 2006 (table 4) when the least rainfall occurred. This occurred in spite of the fact that basin-weighted average rainfall in the Indian Creek watershed was lower each year than the Blue River (table 2). Generally, as percent impervious surface (a measure of urbanization) increased, streamflow yield increased (fig. 11A).

\section{pH, Water Temperature, and Dissolved Oxygen}

$\mathrm{pH}$ is a measure of the effective hydrogen ion concentration and is used as an index of the status of chemical and biological equilibrium reactions in water (Hem, 1992). The $\mathrm{pH}$ of natural water generally ranges from 6.5 to 8.5 standard units (Hem, 1992). Kansas aquatic-life-support criteria require that $\mathrm{pH}$ in streams measure not less than 6.5 and not more than 8.5 standard units (Kansas Department of Health and Environment, 2012). Increases in $\mathrm{pH}$ and water temperature result in an increase in the toxicity of ammonia for fish (Kansas Department of Health and Environment, 2005).

Daily variability in $\mathrm{pH}$ is an indication of photosynthetic activity and is affected by availability of sunlight and nutrients (Wetzel, 2001). During the day, photosynthesis by aquatic plants increases the amount of oxygen dissolved in the water and decreases dissolved carbon dioxide, thus increasing $\mathrm{pH}$ during the daytime. Oxygen is consumed and carbon dioxide is released during respiration and decomposition, which take 
Table 3. Annual summary statistics of hourly measured data for streamflow, $\mathrm{pH}$, water temperature, dissolved oxygen, specific conductance, and turbidity, and of hourly computed data for chloride, suspended sediment, total nitrogen, total phosphorus, and Escherichia coli bacteria at continuous monitoring sites in Johnson County, Kansas, 2003-11.

[n, number of values; E. coli, Escherichia coli; --, not available]

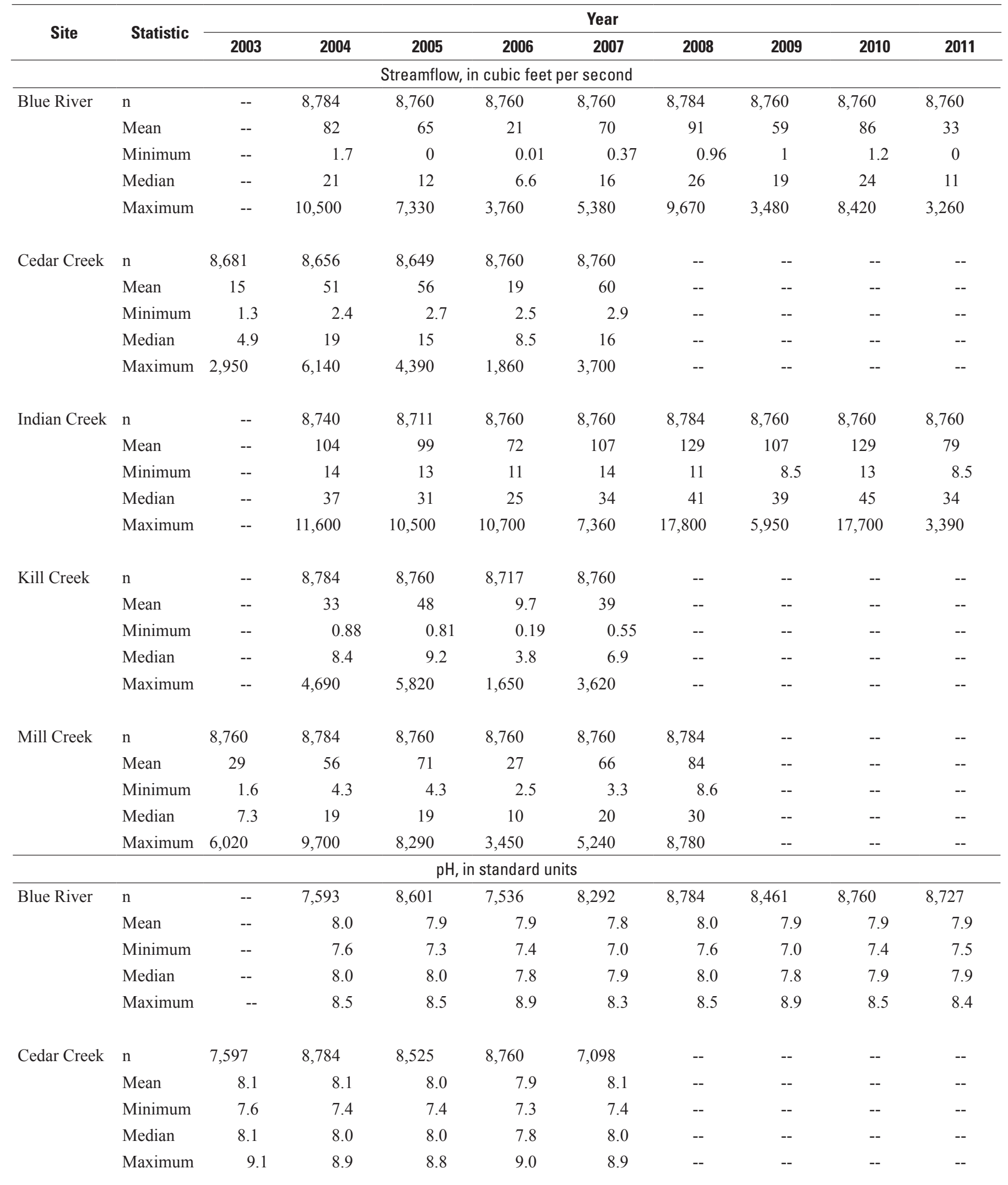


Table 3. Annual summary statistics of hourly measured data for streamflow, $\mathrm{pH}$, water temperature, dissolved oxygen, specific conductance, and turbidity, and of hourly computed data for chloride, suspended sediment, total nitrogen, total phosphorus, and Escherichia coli bacteria at continuous monitoring sites in Johnson County, Kansas, 2003-11.-Continued

[n, number of values; E. coli, Escherichia coli; --, not available]

\begin{tabular}{|c|c|c|c|c|c|c|c|c|c|c|}
\hline \multirow{2}{*}{ Site } & \multirow{2}{*}{ Statistic } & \multicolumn{9}{|c|}{ Year } \\
\hline & & 2003 & 2004 & 2005 & 2006 & 2007 & 2008 & 2009 & 2010 & 2011 \\
\hline \multicolumn{11}{|c|}{$\mathrm{pH}$, in standard units-Continued } \\
\hline \multirow{2}{*}{ Indian Creek } & Mean & -- & 7.8 & 7.7 & 7.5 & 7.7 & 7.8 & 7.8 & 7.8 & 7.8 \\
\hline & Minimum & -- & 7.3 & 7.1 & 6.9 & 7 & 7.2 & 7.1 & 7.2 & 7.1 \\
\hline \multirow[t]{3}{*}{ Kill Creek } & $\mathrm{n}$ & -- & 7,471 & 8,760 & 8,690 & 8,534 & -- & -- & -- & -- \\
\hline & Mean & -- & 7.9 & 7.9 & 8.0 & 8.0 & -- & -- & -- & -- \\
\hline & Minimum & -- & 7.5 & 7.5 & 7.3 & 7.4 & -- & -- & -- & -- \\
\hline \multirow[t]{5}{*}{ Mill Creek } & $\mathrm{n}$ & 8,760 & 8,784 & 8,760 & 8,760 & 6,377 & 8,784 & -- & -- & -- \\
\hline & Mean & 8.1 & 8.0 & 8.0 & 8.0 & 8.0 & 8.0 & -- & -- & -- \\
\hline & Minimum & 7.4 & 7.4 & 7.4 & 7.3 & 7.3 & 7.3 & -- & -- & -- \\
\hline & Median & 8.0 & 8.0 & 8.0 & 7.9 & 8.0 & 8.0 & -- & -- & -- \\
\hline & Maximum & 9.1 & 8.7 & 8.7 & 8.8 & 8.7 & 8.6 & -- & -- & -- \\
\hline \multicolumn{11}{|c|}{ Water temperature, in degrees Celsius } \\
\hline \multirow[t]{3}{*}{ Blue River } & $\mathrm{n}$ & -- & 7,597 & 8,760 & 8,760 & 8,641 & 8,784 & 8,760 & 8,760 & 8,727 \\
\hline & Mean & -- & 15.9 & 14.5 & 14.8 & 14.8 & 13.3 & 13.5 & 14.2 & 14.4 \\
\hline & Minimum & -- & 0.1 & -0.1 & 0.2 & 0.0 & -0.1 & 0.0 & 0.0 & 0.0 \\
\hline \multirow{2}{*}{ Cedar Creek } & Median & 17.3 & 15.4 & 15.0 & 14.8 & 17.0 & -- & -- & -- & -- \\
\hline & Maximum & 31.8 & 31.1 & 30.5 & 32.6 & 32.4 & -- & -- & -- & -- \\
\hline \multirow[t]{5}{*}{ Indian Creek } & $\mathrm{n}$ & -- & 7,637 & 8,723 & 8,760 & 8,626 & 8,784 & 8,699 & 8,708 & 8,760 \\
\hline & Mean & -- & 17.3 & 16.0 & 16.3 & 16.0 & 14.7 & 14.9 & 15.5 & 15.8 \\
\hline & Minimum & -- & 1.3 & 1.1 & 1.4 & 0.0 & 0.1 & 0.2 & 0.1 & 0.2 \\
\hline & Median & -- & 18.3 & 16.3 & 15.8 & 17.3 & 15.0 & 14.8 & 15.9 & 15.6 \\
\hline & Maximum & -- & 31.8 & 32.5 & 33.0 & 32.0 & 33.1 & 31.8 & 32.2 & 34.7 \\
\hline \multirow[t]{5}{*}{ Kill Creek } & $\mathrm{n}$ & -- & 7,479 & 8,760 & 8,692 & 8,573 & -- & -- & -- & -- \\
\hline & Mean & -- & 16.5 & 14.7 & 14.9 & 14.5 & -- & -- & -- & -- \\
\hline & Minimum & -- & 0.2 & 0.0 & 0.5 & -0.1 & -- & -- & -- & -- \\
\hline & Median & -- & 17.6 & 14.9 & 15.0 & 16.0 & -- & -- & -- & -- \\
\hline & Maximum & -- & 29.6 & 32.1 & 32.9 & 32.6 & -- & -- & -- & -- \\
\hline
\end{tabular}


Table 3. Annual summary statistics of hourly measured data for streamflow, $\mathrm{pH}$, water temperature, dissolved oxygen, specific conductance, and turbidity, and of hourly computed data for chloride, suspended sediment, total nitrogen, total phosphorus, and Escherichia coli bacteria at continuous monitoring sites in Johnson County, Kansas, 2003-11.-Continued

[n, number of values; E. coli, Escherichia coli; --, not available]

\begin{tabular}{|c|c|c|c|c|c|c|c|c|c|c|}
\hline \multirow{2}{*}{ Site } & \multirow{2}{*}{ Statistic } & \multicolumn{9}{|c|}{ Year } \\
\hline & & 2003 & 2004 & 2005 & 2006 & 2007 & 2008 & 2009 & 2010 & 2011 \\
\hline \multicolumn{11}{|c|}{ Water temperature, in degrees Celsius-Continued } \\
\hline \multirow{2}{*}{ Mill Creek } & Mean & 14.6 & 14.5 & 14.9 & 15.2 & 14.7 & 13.7 & -- & -- & -- \\
\hline & Minimum & 0.2 & 0.0 & 0.1 & 0.2 & -0.1 & -0.1 & -- & -- & -- \\
\hline \multicolumn{11}{|c|}{ Dissolved oxygen, in milligrams per liter } \\
\hline \multirow[t]{3}{*}{ Blue River } & $\mathrm{n}$ & -- & 7,150 & 8,340 & 8,612 & 8,238 & 8,784 & 8,760 & 8,760 & 8,727 \\
\hline & Mean & -- & 9.2 & 8.9 & 8.7 & 9.0 & 10.1 & 9.7 & 9.5 & 9.0 \\
\hline & Minimum & -- & 4.2 & 1.8 & 2.0 & 2.1 & 3.8 & 4.1 & 3.8 & 1.2 \\
\hline \multirow[t]{5}{*}{ Cedar Creek } & $\mathrm{n}$ & 7,538 & 7,886 & 8,567 & 8,420 & 7,925 & -- & -- & -- & -- \\
\hline & Mean & 9.5 & 9.5 & 9.5 & 9.6 & 10.2 & -- & -- & -- & -- \\
\hline & Minimum & 1.2 & 4.7 & 3.1 & 3.2 & 4.2 & -- & -- & -- & -- \\
\hline & Median & 8.9 & 9.0 & 9.2 & 9.0 & 9.8 & -- & -- & -- & -- \\
\hline & Maximum & 22.9 & 18.8 & 18.1 & 21.4 & 19.0 & -- & -- & -- & -- \\
\hline \multirow[t]{3}{*}{ Indian Creek } & $\mathrm{n}$ & -- & 6,729 & 8,132 & 7,890 & 7,879 & 8,536 & 8,699 & 8,708 & 8,760 \\
\hline & Mean & -- & 8.2 & 8.4 & 7.6 & 8.3 & 8.3 & 8.8 & 8.5 & 8.1 \\
\hline & Minimum & -- & 1.9 & 1.5 & 0.9 & 1.3 & 0.6 & 3.3 & 2.4 & 1.5 \\
\hline \multirow{2}{*}{ Kill Creek } & Median & -- & 8.5 & 9.3 & 8.4 & 8.8 & -- & -- & -- & -- \\
\hline & Maximum & -- & 16.5 & 17.7 & 21.2 & 19.8 & -- & -- & -- & -- \\
\hline \multirow[t]{5}{*}{ Mill Creek } & $\mathrm{n}$ & 8,710 & 8,064 & 8,475 & 8,331 & 8,081 & 8,784 & -- & -- & -- \\
\hline & Mean & 10.6 & 11.2 & 10.4 & 9.7 & 10.2 & 10.3 & -- & -- & -- \\
\hline & Minimum & 1.8 & 5.0 & 3.0 & 1.0 & 3.3 & 4.5 & -- & -- & -- \\
\hline & Median & 9.9 & 10.3 & 9.8 & 9.2 & 9.6 & 9.9 & -- & -- & -- \\
\hline & Maximum & 21.0 & 24.0 & 21.8 & 17.8 & 19.7 & 18.4 & -- & -- & -- \\
\hline \multicolumn{11}{|c|}{ Specific conductance, in microseimens per centimeter at 25 degrees Celsius } \\
\hline \multirow[t]{5}{*}{ Blue River } & $\mathrm{n}$ & -- & 7,590 & 8,760 & 8,760 & 8,632 & 8,575 & 8,760 & 8,703 & 8,727 \\
\hline & Mean & -- & 546 & 569 & 608 & 570 & 560 & 538 & 550 & 571 \\
\hline & Minimum & -- & 149 & 164 & 143 & 162 & 114 & 182 & 111 & 172 \\
\hline & Median & -- & 565 & 590 & 625 & 592 & 557 & 547 & 562 & 575 \\
\hline & Maximum & -- & 790 & 832 & 752 & 897 & 820 & 718 & 792 & 801 \\
\hline
\end{tabular}


Table 3. Annual summary statistics of hourly measured data for streamflow, $\mathrm{pH}$, water temperature, dissolved oxygen, specific conductance, and turbidity, and of hourly computed data for chloride, suspended sediment, total nitrogen, total phosphorus, and Escherichia coli bacteria at continuous monitoring sites in Johnson County, Kansas, 2003-11.-Continued

[n, number of values; E. coli, Escherichia coli; --, not available]

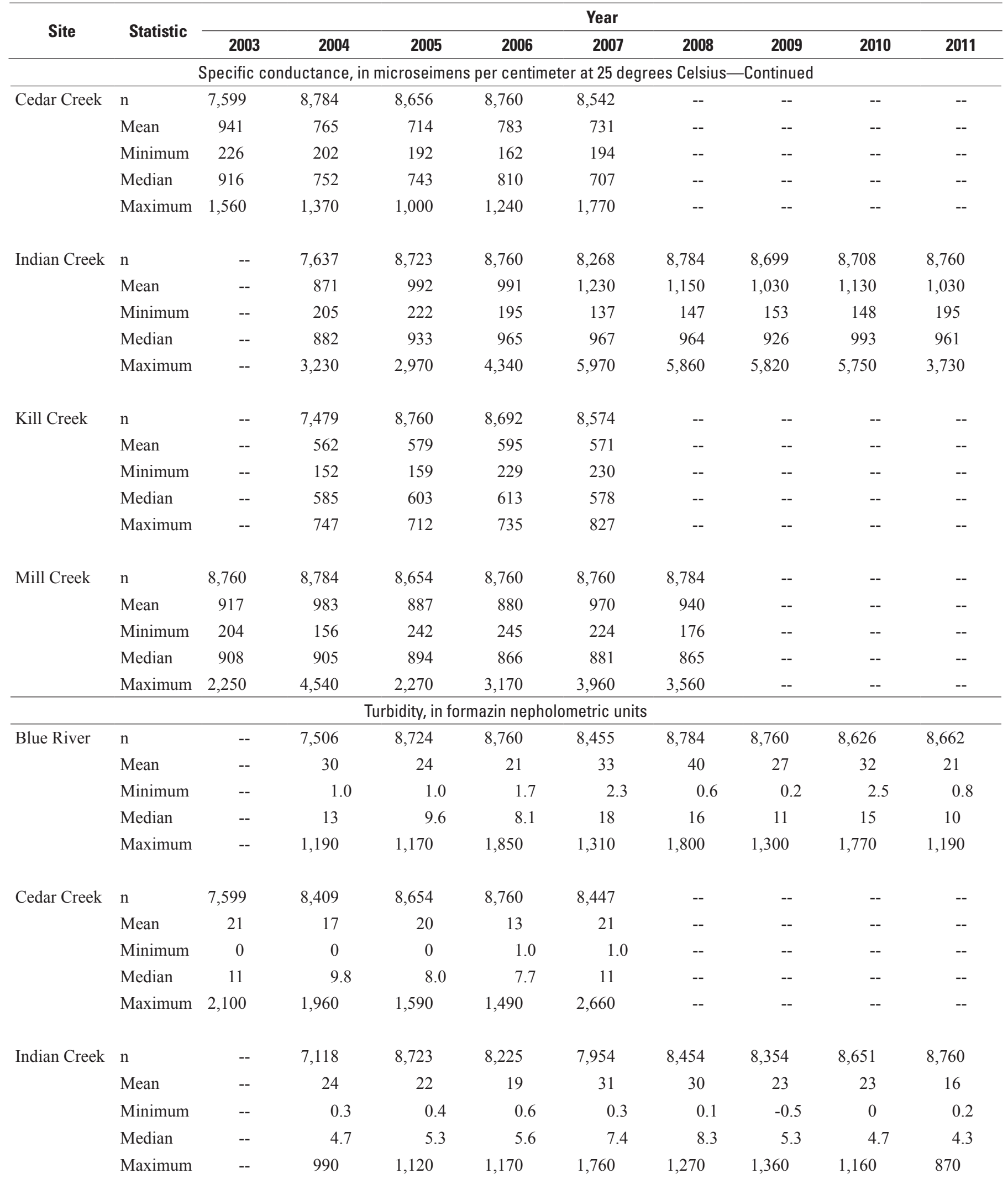


Table 3. Annual summary statistics of hourly measured data for streamflow, $\mathrm{pH}$, water temperature, dissolved oxygen, specific conductance, and turbidity, and of hourly computed data for chloride, suspended sediment, total nitrogen, total phosphorus, and Escherichia coli bacteria at continuous monitoring sites in Johnson County, Kansas, 2003-11.-Continued

[n, number of values; E. coli, Escherichia coli; --, not available]

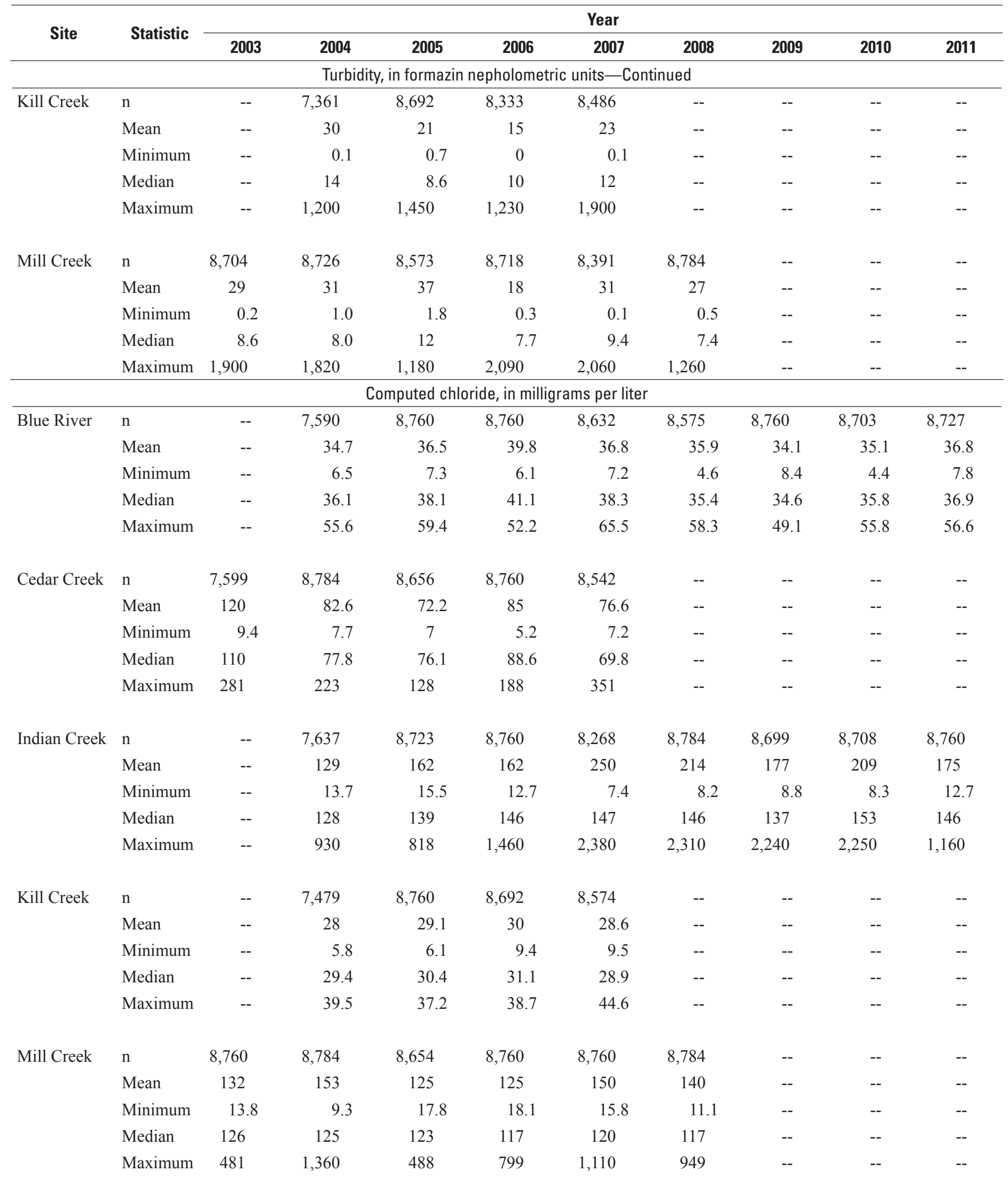


Table 3. Annual summary statistics of hourly measured data for streamflow, $\mathrm{pH}$, water temperature, dissolved oxygen, specific conductance, and turbidity, and of hourly computed data for chloride, suspended sediment, total nitrogen, total phosphorus, and Escherichia coli bacteria at continuous monitoring sites in Johnson County, Kansas, 2003-11.-Continued

[n, number of values; E. coli, Escherichia coli; --, not available]

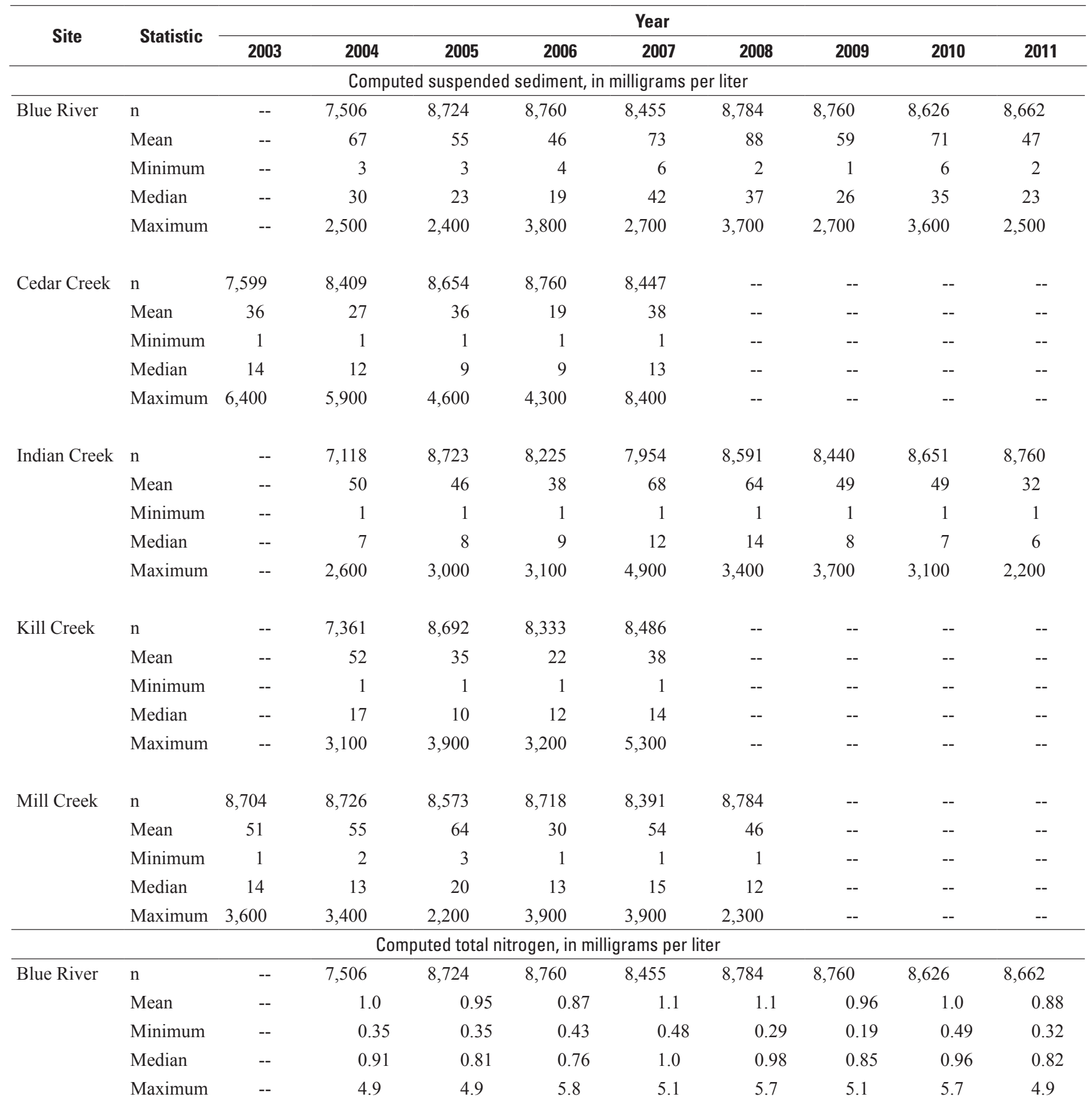

Cedar Creek n

Mean

Minimum

Median

Maximum 
Table 3. Annual summary statistics of hourly measured data for streamflow, $\mathrm{pH}$, water temperature, dissolved oxygen, specific conductance, and turbidity, and of hourly computed data for chloride, suspended sediment, total nitrogen, total phosphorus, and Escherichia coli bacteria at continuous monitoring sites in Johnson County, Kansas, 2003-11.-Continued

[n, number of values; E. coli, Escherichia coli; --, not available]

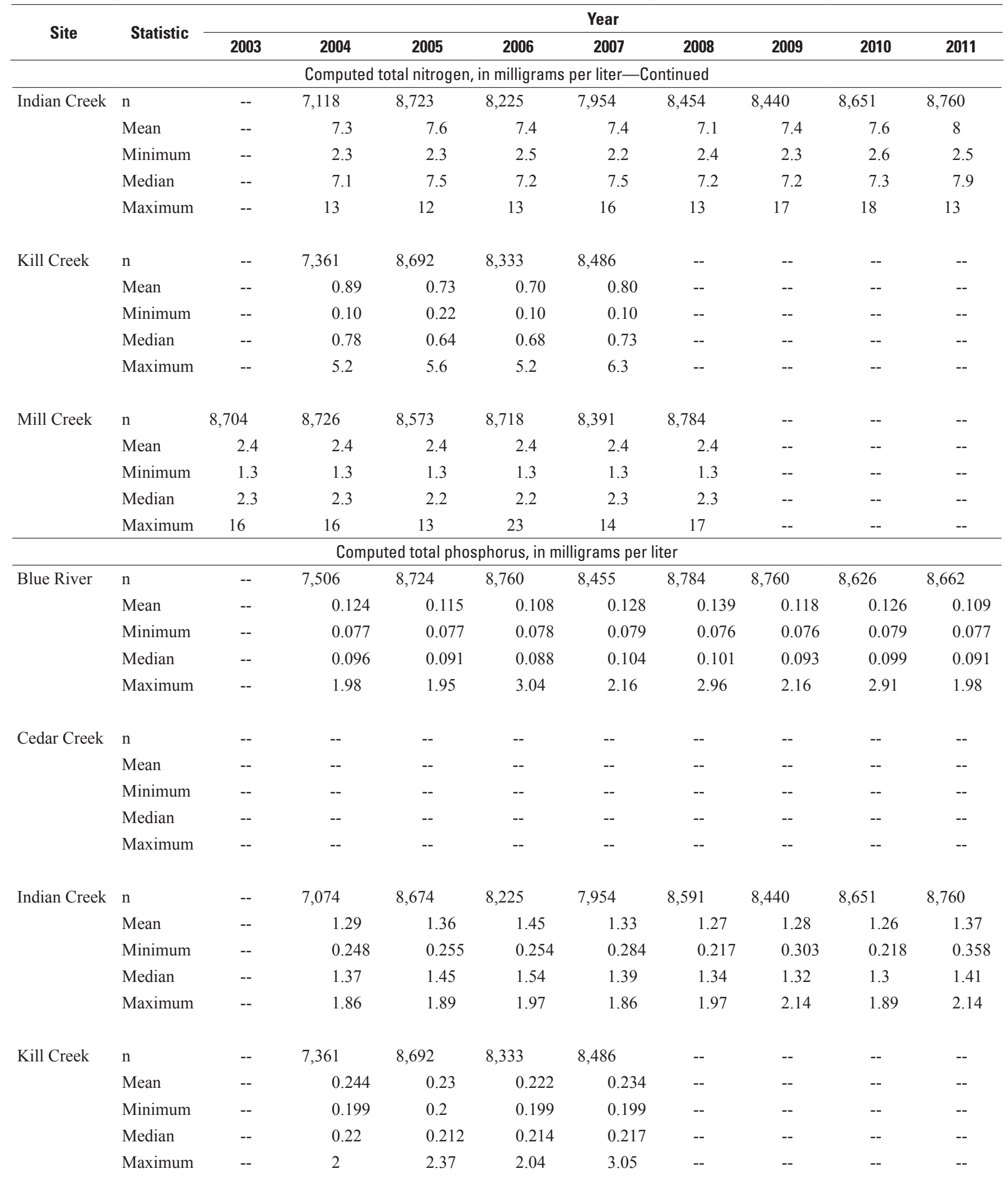


Table 3. Annual summary statistics of hourly measured data for streamflow, $\mathrm{pH}$, water temperature, dissolved oxygen, specific conductance, and turbidity, and of hourly computed data for chloride, suspended sediment, total nitrogen, total phosphorus, and Escherichia coli bacteria at continuous monitoring sites in Johnson County, Kansas, 2003-11.—Continued

[n, number of values; E. coli, Escherichia coli; --, not available]

\begin{tabular}{|c|c|c|c|c|c|c|c|c|c|c|}
\hline \multirow{2}{*}{ Site } & \multirow{2}{*}{ Statistic } & \multicolumn{9}{|c|}{ Year } \\
\hline & & 2003 & 2004 & 2005 & 2006 & 2007 & 2008 & 2009 & 2010 & 2011 \\
\hline \multicolumn{11}{|c|}{ Computed total phosphorus, in milligrams per liter-Continued } \\
\hline \multirow[t]{5}{*}{ Mill Creek } & $\mathrm{n}$ & 8,704 & 8,726 & 8,573 & 8,718 & 8,391 & 8,784 & -- & -- & -- \\
\hline & Mean & 0.47 & 0.47 & 0.462 & 0.443 & 0.475 & 0.457 & -- & -- & -- \\
\hline & Minimum & 0.288 & 0.288 & 0.29 & 0.289 & 0.29 & 0.289 & -- & -- & -- \\
\hline & Median & 0.443 & 0.439 & 0.431 & 0.427 & 0.444 & 0.434 & -- & -- & -- \\
\hline & Maximum & 7.5 & 8 & 3.34 & 8 & 4 & 4.65 & -- & -- & -- \\
\hline \multicolumn{11}{|c|}{ Computed $E$. coli bacteria, in colonies per 100 milliliter } \\
\hline \multirow[t]{5}{*}{ Blue River } & $\mathrm{n}$ & -- & 7,506 & 8,724 & 8,760 & 8,455 & 8,784 & 8,760 & 8,626 & 8,662 \\
\hline & Mean & -- & 210 & 130 & 140 & 210 & 320 & 180 & 220 & 130 \\
\hline & Minimum & -- & 1 & 0 & 2 & 3 & 1 & 1 & 4 & 1 \\
\hline & Median & -- & 38 & 20 & 20 & 59 & 50 & 30 & 46 & 26 \\
\hline & Maximum & -- & 19,000 & 18,000 & 35,000 & 21,000 & 33,000 & 21,000 & 33000 & 19,000 \\
\hline \multirow[t]{5}{*}{ Cedar Creek } & $\mathrm{n}$ & 7,599 & 8,409 & 8,654 & 8,760 & 8,447 & -- & -- & -- & -- \\
\hline & Mean & 410 & 260 & 470 & 170 & 480 & -- & -- & -- & -- \\
\hline & Minimum & 1 & 1 & 1 & 1 & 1 & -- & -- & -- & -- \\
\hline & Median & 57 & 47 & 34 & 32 & 56 & -- & -- & -- & -- \\
\hline & Maximum & 180,000 & 160,000 & 120,000 & 110,000 & 260,000 & -- & -- & -- & -- \\
\hline \multirow[t]{5}{*}{ Indian Creek } & $\mathrm{n}$ & -- & 7,118 & 8,723 & 8,225 & 7,954 & 8,591 & 8,440 & 8,651 & 8,760 \\
\hline & Mean & -- & 1,800 & 1,700 & 1,400 & 2,400 & 2,300 & 1,800 & 1,800 & 1,200 \\
\hline & Minimum & -- & 21 & 28 & 42 & 21 & 42 & 7 & 7 & 14 \\
\hline & Median & -- & 340 & 390 & 410 & 540 & 640 & 390 & 340 & 310 \\
\hline & Maximum & -- & 79,000 & 90,000 & 94,000 & 140,000 & 100,000 & 110,000 & 93,000 & 70,000 \\
\hline \multirow[t]{5}{*}{ Kill Creek } & $\mathrm{n}$ & -- & 7,361 & 8,692 & & 8,486 & -- & -- & -- & -- \\
\hline & Mean & -- & 710 & 460 & 270 & 510 & -- & -- & -- & -- \\
\hline & Minimum & -- & 1 & 4 & 1 & 1 & -- & -- & -- & -- \\
\hline & Median & -- & 180 & 94 & 120 & 150 & -- & -- & -- & -- \\
\hline & Maximum & -- & 55,000 & 70,000 & 57,000 & 100,000 & -- & -- & -- & -- \\
\hline \multirow[t]{5}{*}{ Mill Creek } & $\mathrm{n}$ & 8,704 & 8,726 & 8,573 & 8,718 & 8,391 & 8,784 & -- & -- & -- \\
\hline & Mean & 530 & 570 & 650 & 270 & 560 & 470 & -- & -- & -- \\
\hline & Minimum & 1 & 6 & 12 & 1 & 1 & 2 & -- & -- & -- \\
\hline & Median & 79 & 72 & 120 & 68 & 87 & 65 & -- & -- & -- \\
\hline & Maximum & 58,000 & 55,000 & 33,000 & 65,000 & 64,000 & 35,000 & -- & -- & -- \\
\hline
\end{tabular}



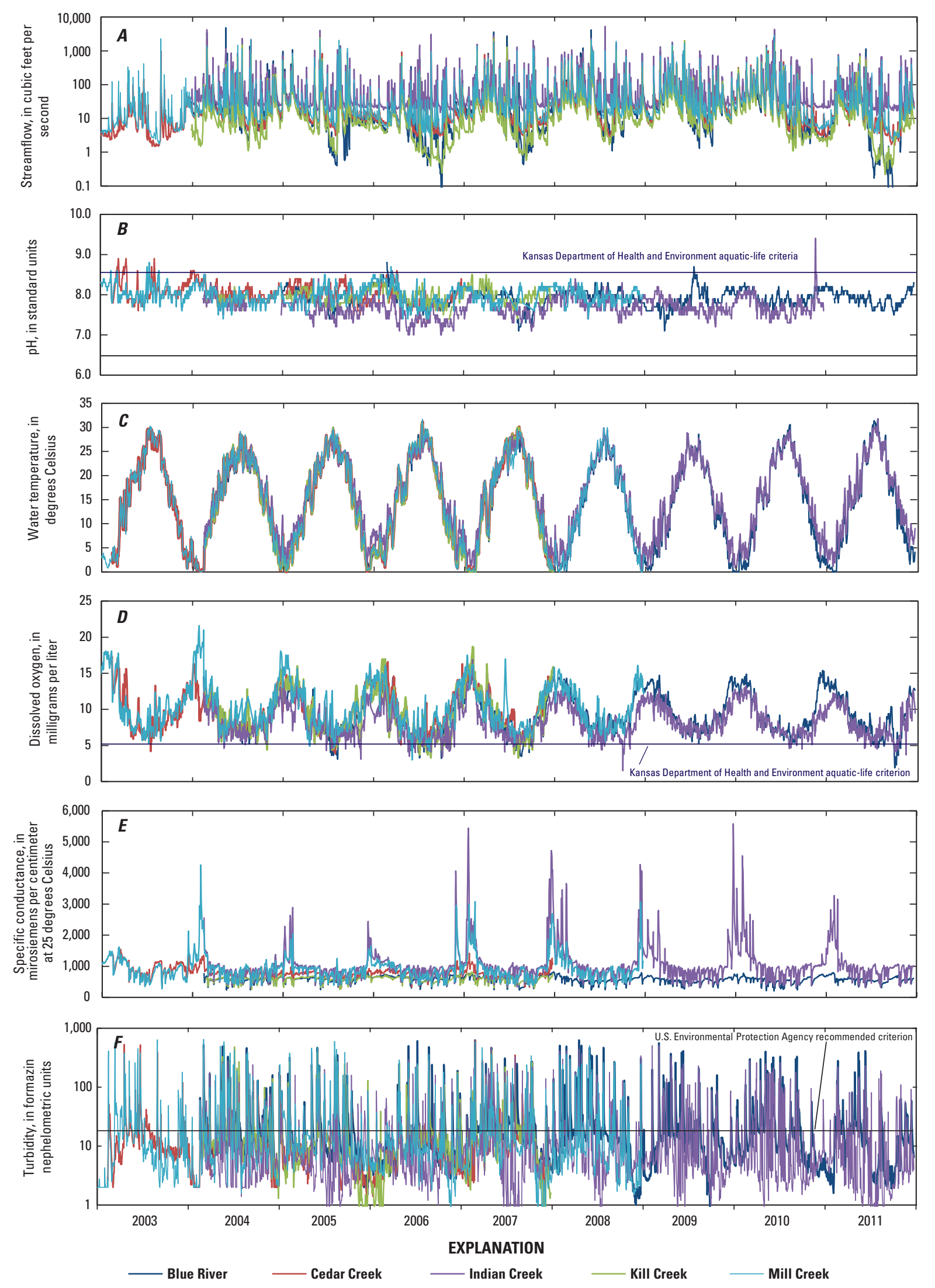

Figure 7. Continuous daily values for $A$, streamflow; $B, \mathrm{pH}$; $C$, water temperature; $D$, dissolved oxygen; $E$, specific conductance; and $F$, turbidity at monitoring sites in Johnson County, Kansas, 2003-11. 

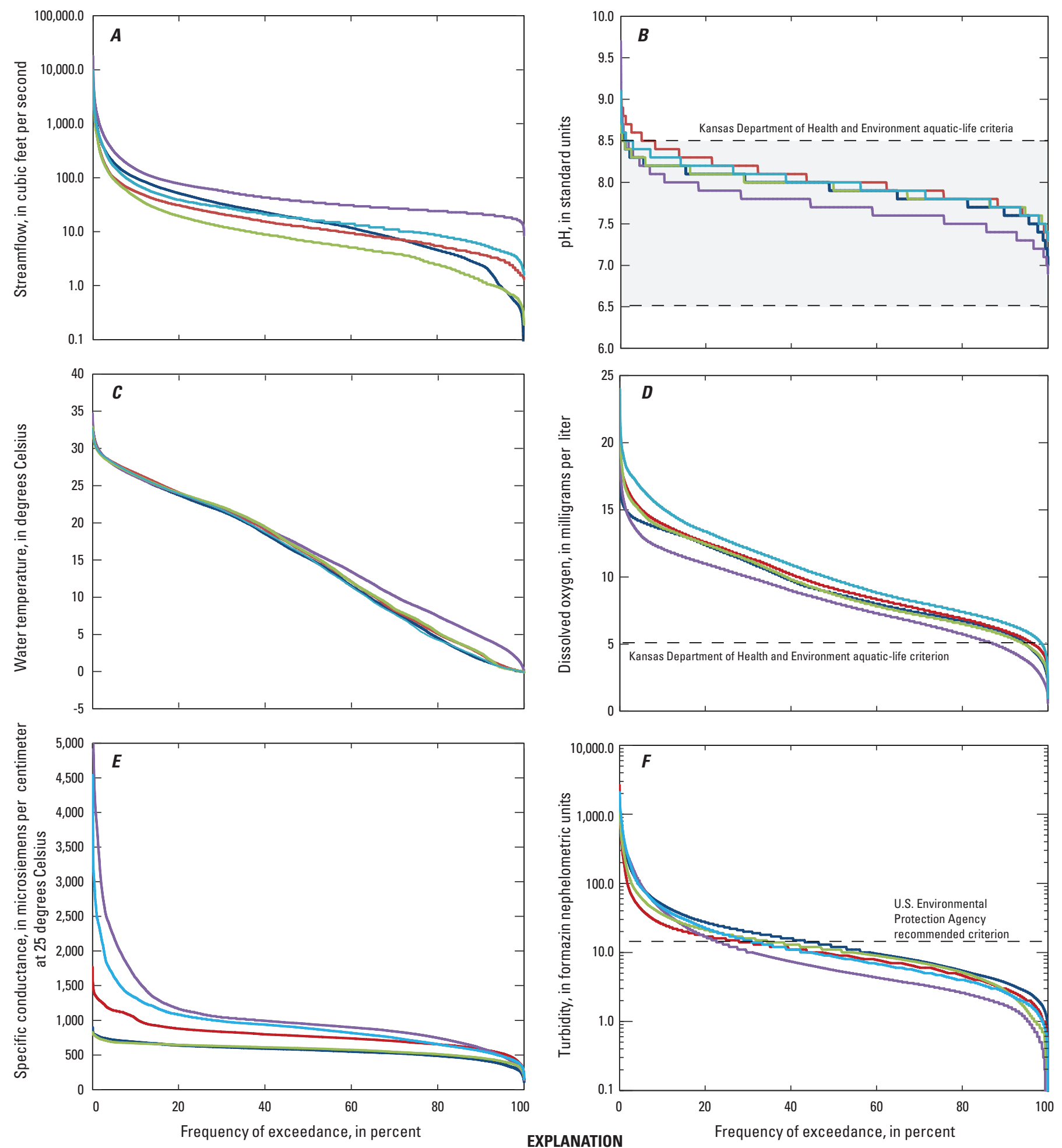

EXPLANATION

Indian Creek (2004-11)

Mill Creek (2003-08)

Blue River (2004-11)

Cedar Creek (2003-07)

Kill Creek (2004-07)

Figure 8. Period-of-record duration curves for hourly measured $A$, streamflow; $B, \mathrm{pH} ; C$, water temperature; $D$, dissolved oxygen; $E$, specific conductance; and $F$, turbidity at monitoring sites in Johnson County, Kansas, 2003-11. 

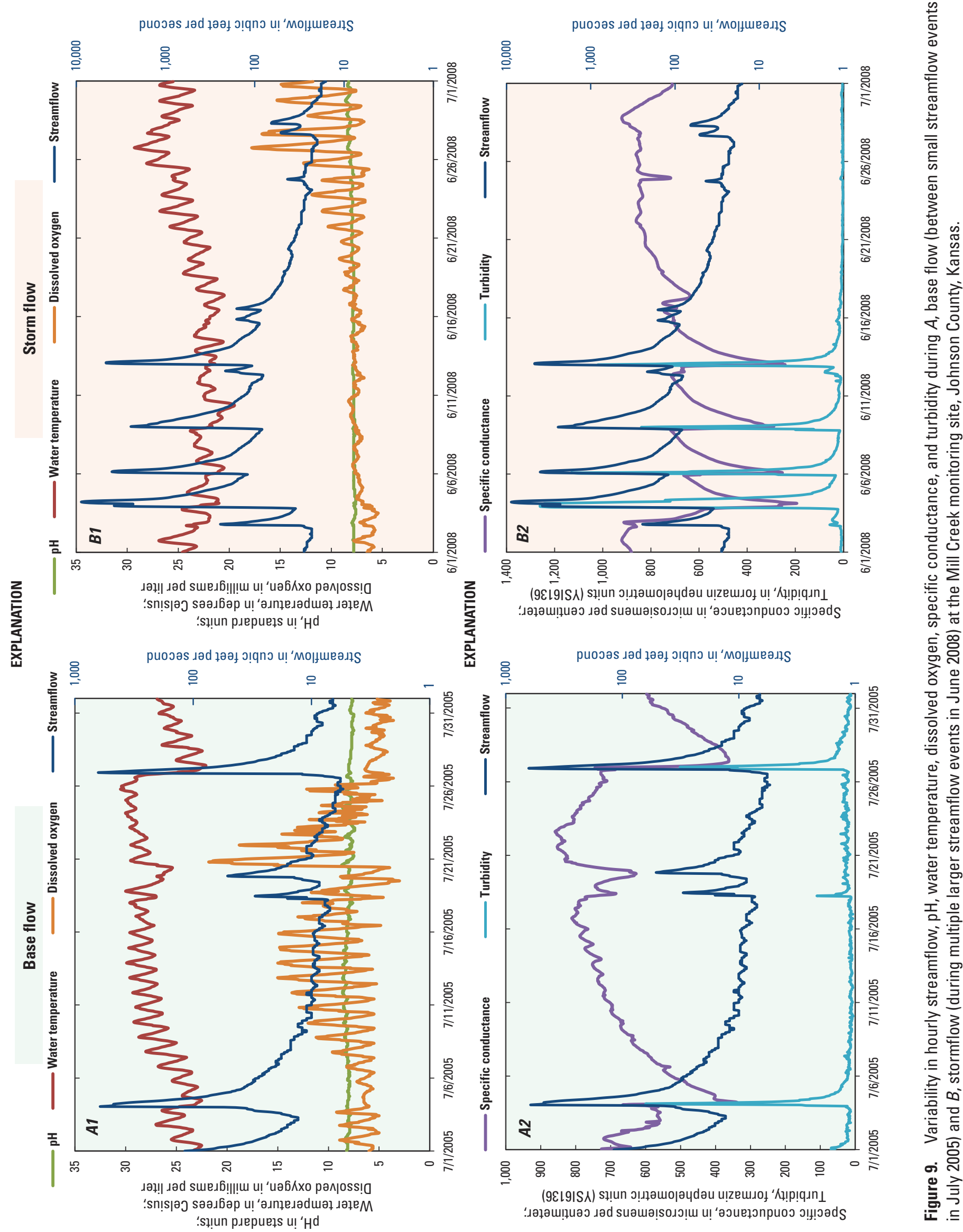

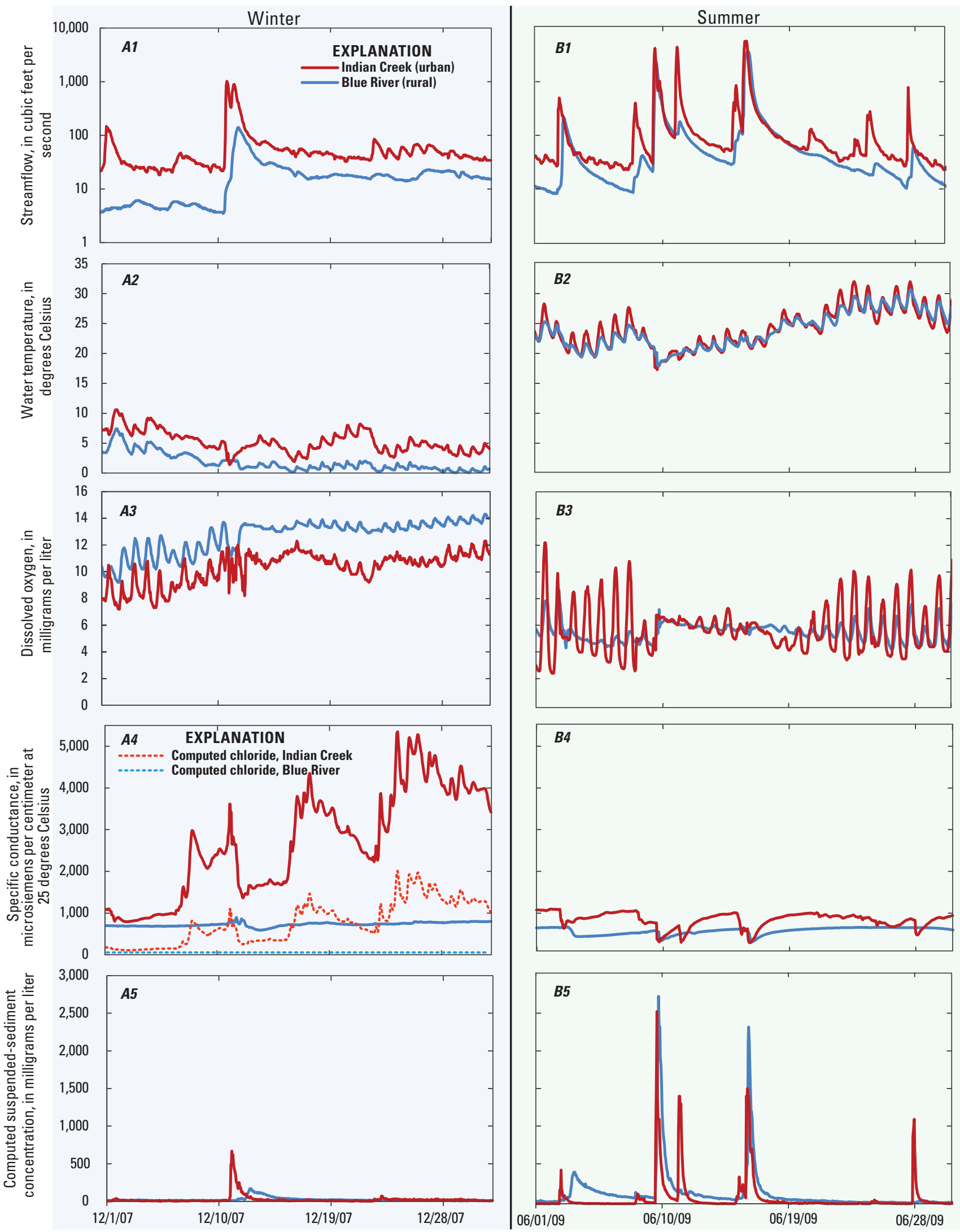

Figure 10. Variability in rural (Blue River) and urban (Indian Creek) streams, including streamflow, water temperature, dissolved oxygen, specific conductance, chloride, and suspended sediment during $A$, winter (December 2007) and $B$, summer (June 2009), Johnson County, Kansas. 
Table 4. Annual streamflow volume, and annual streamflow yield at monitoring sites in Johnson County, Kansas, 2003-11.

[--, not available]

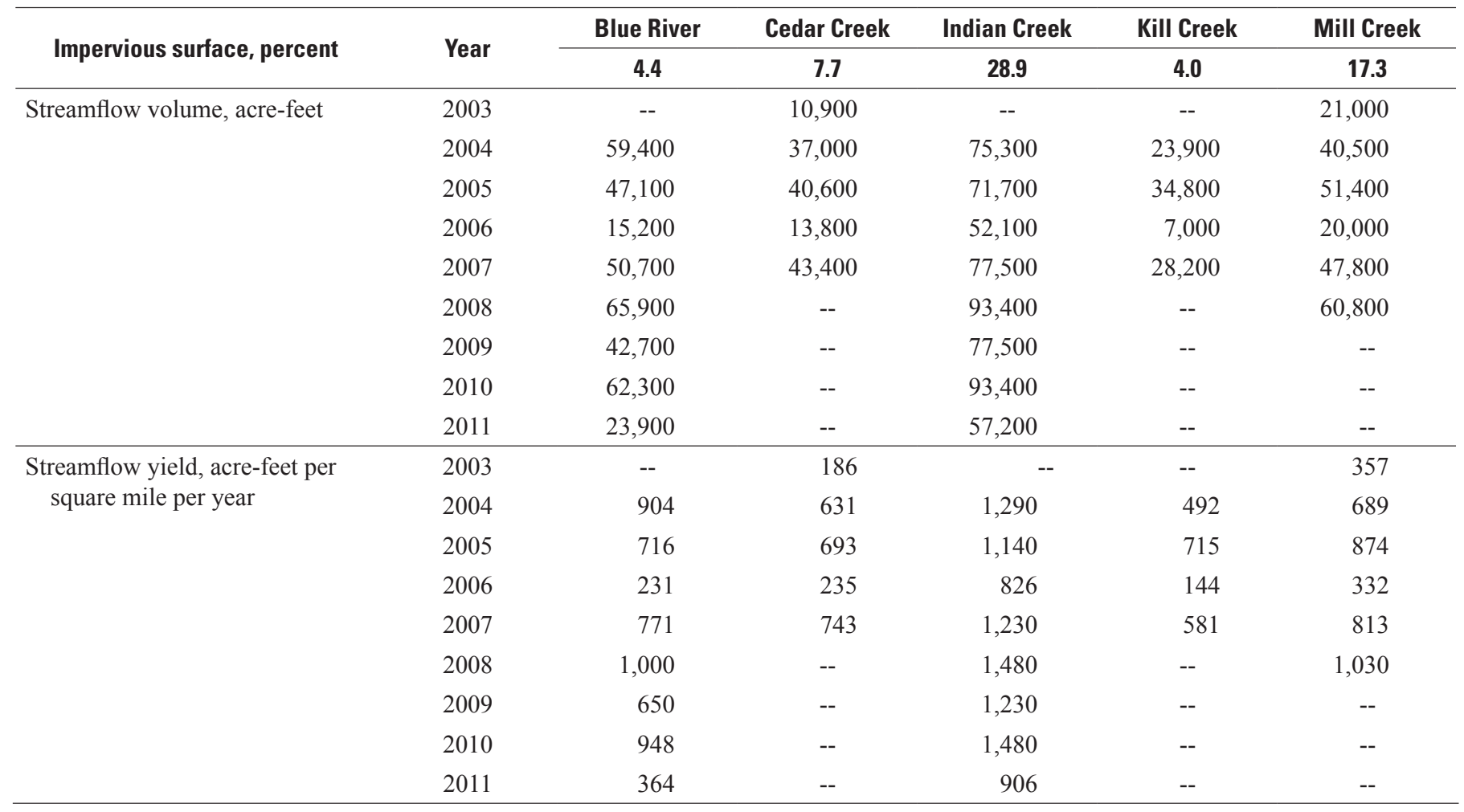

place throughout the day and night, resulting in lower $\mathrm{pH}$ during the night. $\mathrm{pH}$ of streams in northeastern Kansas has been found to be slightly elevated primarily because of the buffering capacity of the surficial soils and rocks (Jordan and Stamer, 1995).

$\mathrm{pH}$ was never less than 6.9 at any of the sites during the study period (table 3 ). $\mathrm{pH}$ exceeded 8.5 at each site during the study period (table 3), most frequently at the Cedar Creek site (about 10 percent of the time, fig. 8B). Exceedence at the Cedar Creek site was recorded primarily early in the monitoring period (2003-04, fig. 7B). pH at the Indian Creek site was lowest of the five sites most of the time (fig. $8 B$ ). Urban runoff often is more acidic than runoff from other land uses (Welch and Lindell, 1992), and $\mathrm{pH}$ often decreases during runoff at this site. In addition, during base flow, streamflow at this site primarily consists of discharge from nearby WWTF. Although $\mathrm{pH}$ is affected by temperature, in Johnson County streams seasonal cycles in $\mathrm{pH}$ are not as prominent as in other measured parameters (fig. 7).

Water temperature affects the density of water, the solubility of constituents in water, specific conductance, $\mathrm{pH}$, the rate of chemical reactions, and biological activity in water (Wilde, 2006). High water temperatures can result in larger fluctuations in dissolved oxygen, which can be harmful to invertebrates and fish (Kaushal and others, 2010). Kansas aquatic-life-support criteria require that discharges to streams not raise the water temperature more than $3{ }^{\circ} \mathrm{C}$ or raise the temperature above $32^{\circ} \mathrm{C}$ (Kansas Department of Health and Environment, 2005).
Daily values of water temperature were similar for all of the monitoring sites during the study period (fig. $7 C$ ). However, hourly values that more accurately characterize variability indicated the water temperature of Indian Creek was higher than the other sites when temperatures were less than about 15 degrees Celsius (fig. 8C). Besides being affected by warmer wastewater discharges, increased water temperature in urban streams may be caused by the decrease in streamside shade from loss of riparian habitat, heating of runoff from roads and parking lots, and generally warmer temperatures formed by cities (Galli, 1991; LeBlanc and others, 1997; Paul and Meyer, 2001; Coles and others, 2012). Daily fluctuations in temperature were recorded in Johnson County streams, for example Mill Creek, during base flow and, with much less variability, stormflow (fig. 9, $A 1$ and $B 1$ ), and are larger during summer at the urban stream site (fig. 10, B2). Daily stream temperature fluctuates primarily as a result of heat exchange with the ambient air, and larger fluctuations generally occur during the summer, during lower streamflow, and in streams that are more shallow and wide (Webb and others, 2008). Stream temperatures in urban areas also are affected by loss of shading, wastewater inputs, and wash-off from hot pavements (Webb and others, 2008).

Dissolved oxygen (DO) concentration is an important factor in chemical reactions and the survival of aquatic organisms. It is affected by many factors, including ambient temperature, atmospheric pressure, and ionic strength of the water body (Rounds and others, 2013). Kansas aquatic-life-support 

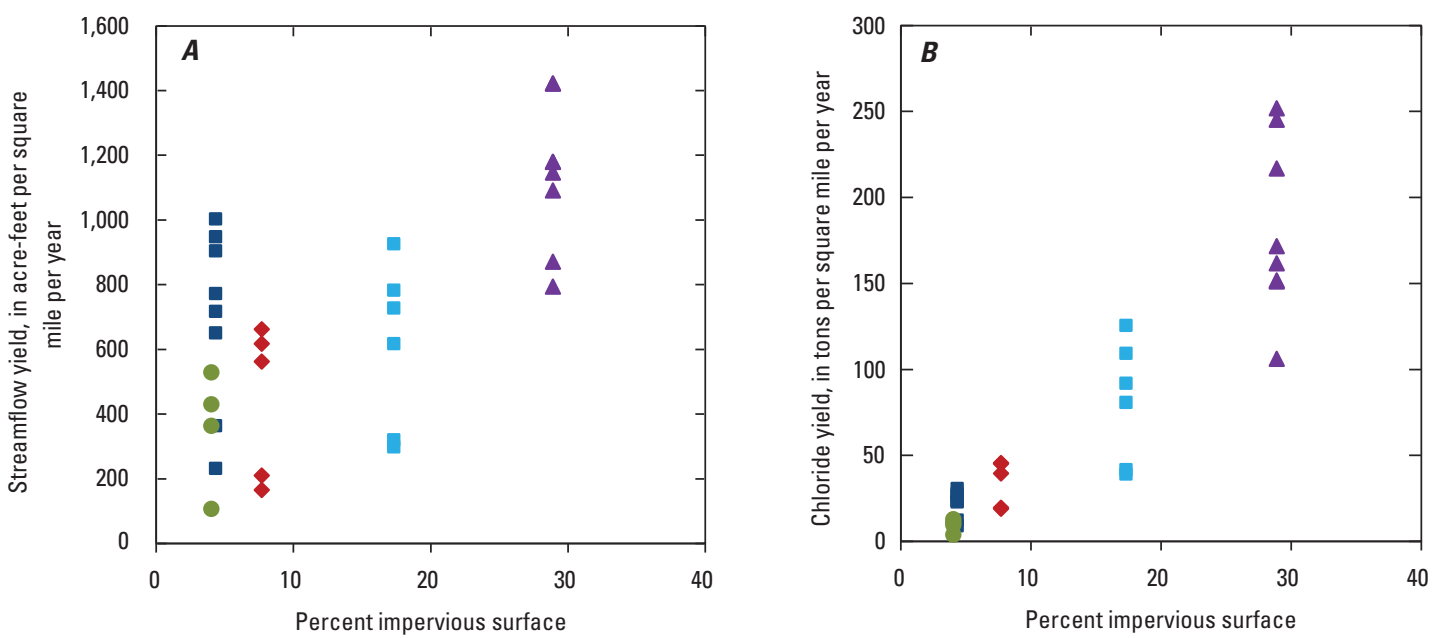

EXPLANATION

- Blue River

- Cedar Creek

Indian Creek
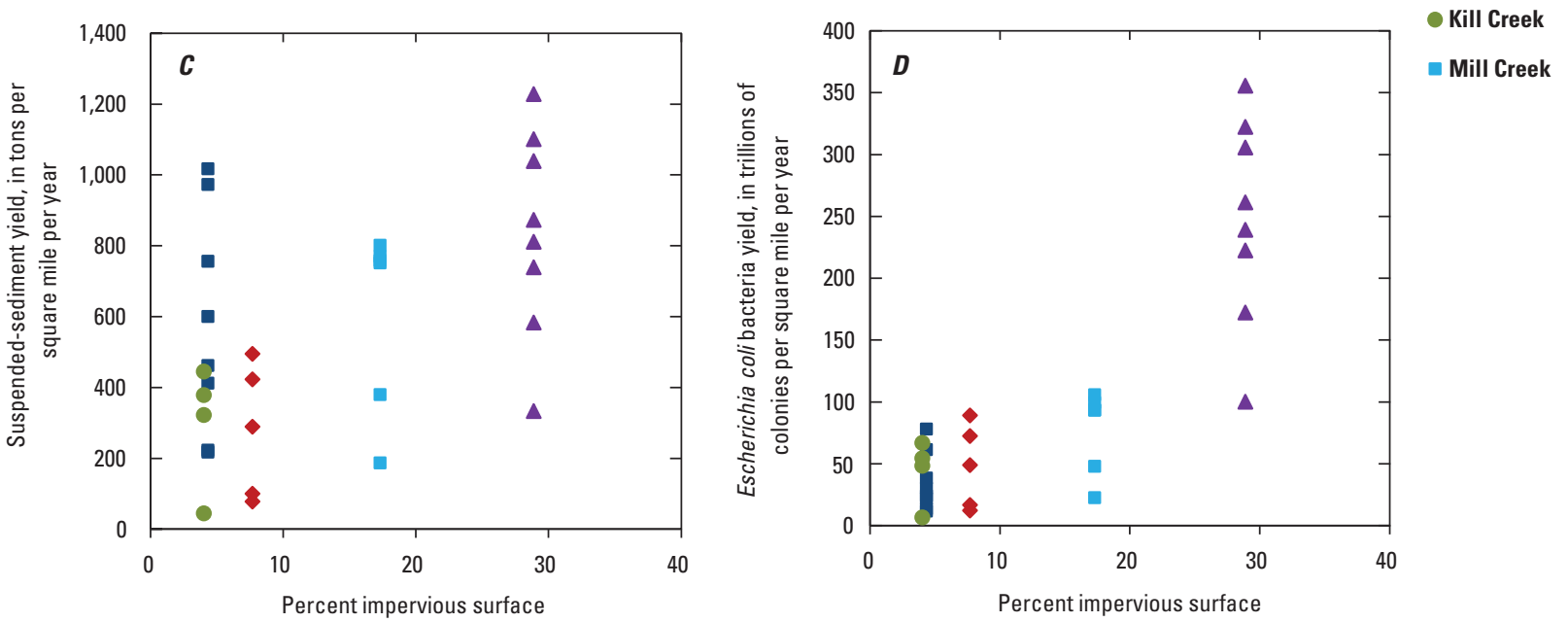

Figure 11. Relations between percent impervious surface area and annual yields for $A$, streamflow; $B$, chloride; $C$, suspended sediment; and $D$, Escherichia coli bacteria at stream monitoring sites in Johnson County, Kansas.

criterion requires that $\mathrm{DO}$ concentrations are not less than $5.0 \mathrm{mg} / \mathrm{L}$ (Kansas Department of Health and Environment, 2012). Although state criteria generally are dependent on discrete sample measurements, the same criterion is being used as a basis for comparison in this report. Daily variability in $\mathrm{DO}$ (and $\mathrm{pH}$ ) is an indication of photosynthetic activity and is affected by availability of sunlight and nutrients (Wetzel, 2001). During the day, photosynthesis by aquatic plants increases the amount of oxygen dissolved in the water. Oxygen is consumed during respiration and decomposition, which occur throughout the day and night, resulting in lower DO during the night.

Hourly DO concentrations during the study period ranged from 0.6 milligrams per liter $(\mathrm{mg} / \mathrm{L})$ in Indian Creek to $24 \mathrm{mg} / \mathrm{L}$ in the Mill Creek (table 3). With the exception of 2009 and 2011, Indian Creek had the lowest minimum hourly DO annually, at less than $2.0 \mathrm{mg} / \mathrm{L}$ most of the years of the study period (table 3 ). Low DO at all sites was recorded during different seasons but most frequently during the late summer (fig. 7D) and generally corresponded with the lowest streamflow and warmest water temperatures (when oxygen solubility in water is lowest). During the monitoring period for each site, DO concentrations were less than the KDHE criterion of $5 \mathrm{mg} / \mathrm{L}$ about 15 percent of the time at the Indian Creek site, about 10 percent of the time at the rural Blue River and Kill Creek sites, and less than 5 percent of the time at the other sites (fig. $8 D$ ). More frequent low DO at Indian Creek likely was caused by WWTF discharges and other urban sources that contribute nutrients (such as fertilizer) thereby increasing growth of microorganisms and decreasing DO (Wetzel, 2001). Daily DO fluctuations generally were more extreme during stable base flow (fig. $9 B$ ) partly because of increased algal activity. Daily DO fluctuations also generally were larger at the urban sites than rural sites, particularly during summer. DO fluctuations also were larger downstream from WWTFs, which are a source of nutrients. For example, during early June 2009, daily DO varied from about $2 \mathrm{mg} / \mathrm{L}$ to $12 \mathrm{mg} / \mathrm{L}$ in urban Indian Creek (also affected by WWTF discharges), and from about $5 \mathrm{mg} / \mathrm{L}$ to $8 \mathrm{mg} / \mathrm{L}$ in rural Blue River (fig. 10, $B 3)$. DO was most frequently less than $5 \mathrm{mg} / \mathrm{L}$ during years 
corresponding with lowest streamflow. For example, annual hourly DO duration curves for the Blue River during 2004-11 (fig. 12) indicated that DO was less than $5 \mathrm{mg} / \mathrm{L}$ about 12 percent of the time during 2006, the year with the lowest annual streamflow, and about 1 percent of the time during 2008, the year with the highest annual streamflow. Hourly DO concentrations less than $5 \mathrm{mg} / \mathrm{L}$ were measured at all sites every year, indicating that even under optimal climate conditions in undeveloped watersheds such as Kill Creek, DO concentrations may not meet the KDHE aquatic-life criterion. When daily averages are used to compare to the criterion, values less than $5 \mathrm{mg} / \mathrm{L}$ were less frequent and not an annual occurrence (fig. 7D). More frequent data (such as hourly values) better describe actual water-quality conditions and result in different conclusions than data averaged over a period of time (such as daily values).

\section{Specific Conductance and Chloride}

Specific conductance is a measure of the ability of water to conduct an electrical current and is related to the concentration of ionized substances in water (Hem, 1992). It is affected by soil and rock composition; size of the watershed, which affects the distance runoff flows before reaching streams and, thus, the amount of contact with soil; evaporation, which concentrates dissolved solids; and contaminant sources, including constituents contributed by agricultural and urban runoff (Hem, 1992; Jordan and Stamer, 1995). In most Kansas streams, specific conductance is higher during low flow because of groundwater contributions of dissolved carbonate minerals in underlying limestone (Jordan and Stamer, 1995). Specific conductance in stream water can increase as a result of point-source discharges from WWTFs (Lee and others, 2005). Additional sources of dissolved solids include industrial runoff, road salt, fertilizers, sewer line and septic systems, and swimming pool chemicals (Paul and Meyer, 2001).

Hourly specific conductance in Johnson County streams ranged from 111 microsiemens per centimeter $(\mu \mathrm{s} / \mathrm{cm})$ at the Blue River site in 2010 to $5,970 \mu \mathrm{s} / \mathrm{cm}$ at the Indian Creek site in 2007 (table 3). A seasonal pattern is evident, in which specific conductance generally is lowest during spring and summer storm runoff and highest during winter snowmelt following road-salt application (fig. $7 E$ ). Specific conductance was nearly always highest in Indian Creek, the most urban stream ( 98.3 percent), followed by Mill Creek, the second most urban stream (67.4 percent urban, table 1, fig. $8 E$ ). Both streams also have the largest contribution of WWTF discharge. Indian, Mill, and to a lesser extent Cedar Creeks report sharp increases in specific conductance in the 0 - to 15-percent exceedence frequency (fig. $8 E$ ), as a result of the larger episodes that occur during the winter months, which are the primary source of variability. Annual hourly duration curves for the Indian Creek site are nearly identical except during the 25-percent exceedence frequencies when the annual curves diverge (fig. 12B) indicating that sources of specific conductance other than road salt (such as upstream WWTF discharges) are fairly constant. In addition, it is unknown whether road salt may be accumulating in soils or groundwater and contributing to higher specific conductance during seasons besides winter. Although the Cedar Creek watershed is predominantly rural (24.4 percent urban land use), the monitoring site is at a highway bridge (fig. $2 C$ ) where road salt is occasionally applied. Additionally, a major highway about 3.5 miles upstream may be contributing road-salt runoff. Higher specific conductance values in Cedar Creek than the other two rural sites (Blue River and Kill Creek) all of the time (fig. $8 E$ ) may be a result of larger contribution from groundwater at that site, or may be indicative of road-salt residual affecting stream conditions during the remainder of the year. Studies have documented that road salt can accumulate in soil and groundwater resulting in elevated chloride even when no salt is being applied (Kaushal and others, 2005). In addition, an upstream WWTF likely is contributing to higher specific conductance. Specific conductance in the Blue River and Kill Creek, both largely undeveloped watersheds, were similar during the monitoring period with less variability and maximum specific conductance less than $1,000 \mu \mathrm{s} / \mathrm{cm}$. Specific conductance at those sites during the study period likely is similar to other similar sized rural watersheds in northeast Kansas.

Diel specific conductance fluctuations are most apparent during base flow and occur as a result of the changing contribution of WWTF discharges. Large and rapid decreases in specific conductance typically occur in Johnson County streams, for example Mill Creek (fig. 9, $A 2$ ), because runoff dilutes groundwater and WWTF discharges contribute to flow. A general exception is runoff containing road salt with much higher dissolved solids concentrations and specific conductance values. In the Blue River, specific conductance rapidly decreases during higher flow conditions, and then gradually increases to pre-storm values as streamflow decreases (fig. 10, $A 4$ and $B 4$ ). In contrast, road salt contributions in the Indian Creek watershed increase specific conductance values during winter runoff, and WWTF discharges help maintain higher values during base-flow conditions year-round (fig. 10, $A 4$ and B4).

Chloride is one of several dissolved solids in surface water that originate from the decomposition of soils and rocks (Hem, 1992). Dissolved solids in stream water also can increase as a result of sewage, industrial effluents, agricultural runoff, urban runoff, and atmospheric deposition (Maidment, 1993; Wetzel, 2001). Chloride in the form of sodium chloride $(\mathrm{NaCl})$, calcium chloride $(\mathrm{CaCl})$, and magnesium chloride $(\mathrm{MgCl})$, is a major component of road deicers (U.S. Environmental Protection Agency, 2002b). Elevated road-salt concentrations in streams have been reported to cause acute and chronic toxicity to aquatic organisms (Corsi and others, 2010). KDHE has established an acute aquatic-life criterion of $860 \mathrm{mg} / \mathrm{L}$ for chloride (Kansas Department of Health and Environment, 2012). The USEPA-recommended chronic freshwater quality criterion for chloride is $230 \mathrm{mg} / \mathrm{L}$ (U.S. Environmental Protection Agency, 2002a). 

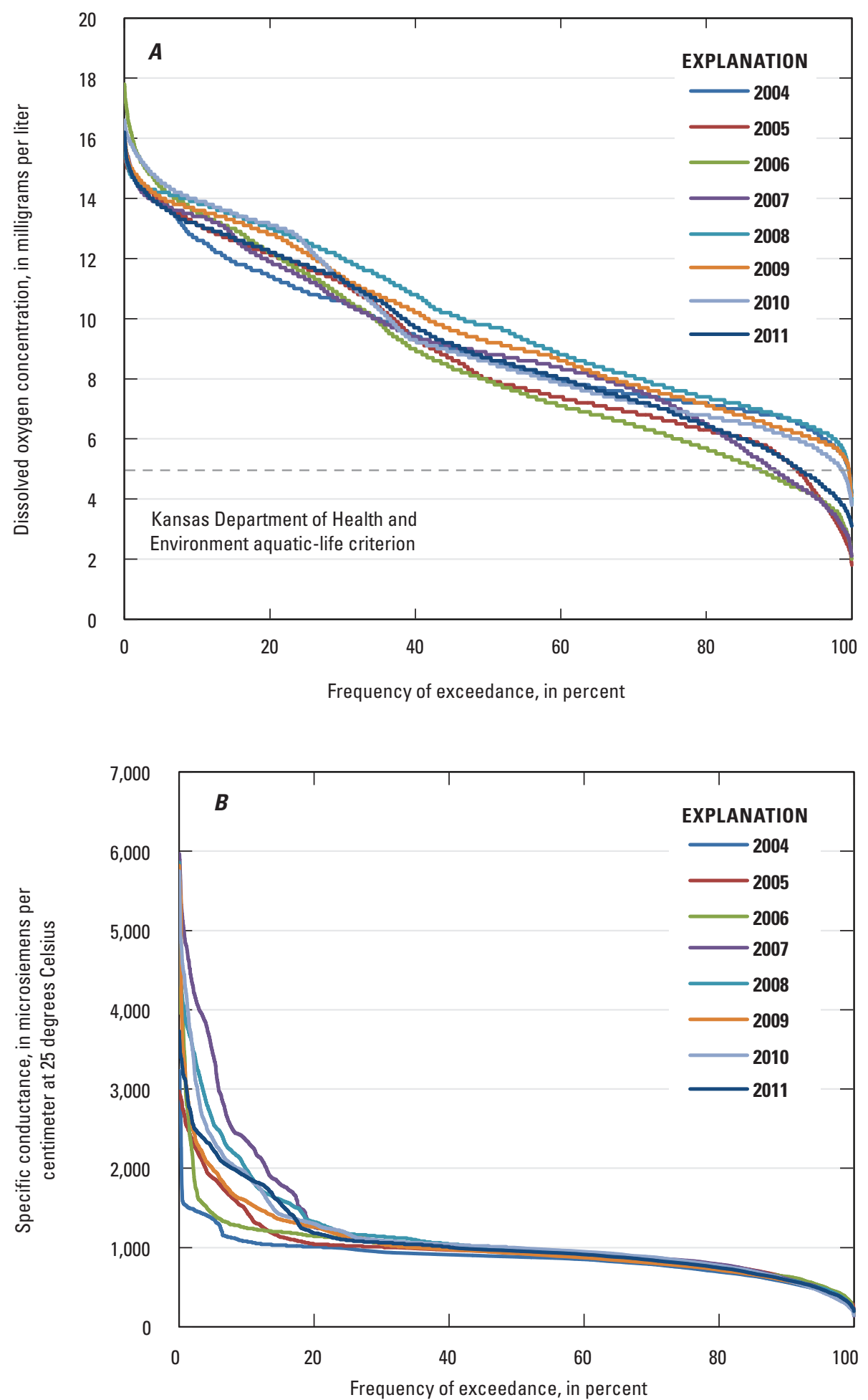

Figure 12. Annual hourly duration curves for $A$, dissolved oxygen at the Blue River monitoring site; and $B$, specific conductance at the Indian Creek monitoring site, in Johnson County, Kansas, 2004-11. 
Specific conductance is the single explanatory variable used for regression models developed to compute chloride (fig. 4A; from Rasmussen and others, 2008; and Graham and others, 2010), because specific conductance is an indirect measure of ionized substances in water. Models are more certain for the most urban sites (Indian and Mill Creeks, fig. 4A). Models for the Blue River and Kill Creek had a lower slope than other models and are less certain (fig. $4 A$ ), because of a smaller range in chloride concentrations and differences in chloride sources at the sites, and, in particular, differences in magnitude caused by road salt (Rasmussen and others, 2008). Because specific conductance is the explanatory variable for chloride, variability in chloride concentrations at monitoring sites occurred in patterns similar to those for specific conductance.

Computed hourly chloride concentrations during the study period ranged from less than $10 \mathrm{mg} / \mathrm{L}$ at all sites, to 2,380 mg/L (table 3) in Indian Creek during January 2007 (fig. 13B). As with specific conductance, WWTF discharges and road salt contributions increased chloride concentrations in the Mill and Indian Creek watersheds (fig. 13, $A$ and $B$ ). The Indian Creek monitoring site also is located at a bridge with large volumes of traffic. Each winter (December, January, February) during the study period, hourly computed chloride concentrations in Indian Creek exceeded the USEPArecommended criterion of $230 \mathrm{mg} / \mathrm{L}$ for at least 10 consecutive days, and during most winters the criterion was exceeded for at least 30 consecutive days (fig. 14). During 2009-10, the USEPA-recommended criterion of $230 \mathrm{mg} / \mathrm{L}$ was exceeded for 73 consecutive days and the KDHE acute aquatic-life criterion of $860 \mathrm{mg} / \mathrm{L}$ was exceeded for 12 consecutive days.

The average annual chloride load during the study period ranged from 611 tons in Kill Creek to 11,900 tons in Indian Creek (table 5, fig. 15). The average annual chloride yield in Indian Creek (189 tons $/ \mathrm{mi}^{2}$ ) was more than double that of Blue River $\left(81 \mathrm{tons} / \mathrm{mi}^{2}\right)$ and at least five times larger than the other three sites (Cedar, Kill, and Mill Creeks). As percent impervious surface (a measure of urbanization) increased, chloride yield increased (fig. 11B).

\section{Turbidity and Suspended Sediment}

Turbidity is caused by suspended and dissolved matter such as clay, silt, finely divided organic matter, plankton and other microscopic organisms, organic acids, and dyes (ASTM International, 2003; Anderson, 2005). Turbidity is affected by the intensity and duration of storms, geomorphic structure of the channel, origin of the water (including point and nonpoint sources), and time of travel from the point of origin to the point of measurement. Biological activity, such as algal blooms, can increase turbidity. Also, increased turbidity reduces light penetration and photosynthesis, smothers benthic habitats, and interferes with feeding activities. Very high values of turbidity for short periods of time may be less harmful than lower values that persist (Wetzel, 2001). USEPA level III ecoregion 40 recommended criterion for turbidity is 15.5 nephelometric turbidity units (U.S. Environmental Protection Agency, 2003). The instruments used in this study measure turbidity in formazin nephelometric units (FNUs) and the criteria are expressed in nephelometric turbidity units (NTUs). An FNU is similar to an NTU in that both measure scattered light at 90 degrees from the incident beam, but different light sources are used which may result in some measurement inconsistencies between the units (Anderson, 2005).

Hourly measured turbidity ranged from less than 2 FNUs at all sites almost every year to more than 2,000 FNUs at the Cedar and Mill Creek sites (table 3, fig. $8 F$ ). The absolute maximum turbidity at sites during the study period is unknown. During some storms (less than 1 percent of the time), turbidity may be missing because of malfunction or may have exceeded the maximum value an individual sensor was capable of measuring. The maximum value varies among individual sensors. The Indian Creek site had the lowest turbidity most of the time (fig. $7 F$ ), because of the high clarity of WWTF discharge, which dominates streamflow at that site most of the time (Lee and others, 2005). Mill Creek turbidity also was lower than the other three sites because of WWTF discharge, even though the discharge occurs about $13 \mathrm{mi}$. upstream from the monitoring site. During the monitored

\section{How to interpret a boxplot}

Boxplots are used to illustrate how results are distributed within a group. The "box" ranges from the 25 th to the 75 th percentile and represents 50 percent of the data. The horizontal line in the middle of the box is the median value-one-half of the values in the group are greater than the median and one-half are less.

Percentiles describe the percentage of values in a group that are less than the given value: 25 percent of the values in a group are less than the 25 th percentile; 75 percent of the values in a group are less than the 75th percentile. The median is also the 50th percentile.

If, for example, the 75th percentile for the measured concentration of a contaminant in a set of samples is equal to the human-health benchmark for that contaminant, then 75 percent, or three-fourths, of the samples have a concentration of that contaminant less than the benchmark, and 25 percent, or one-fourth, have a concentration greater than the benchmark.

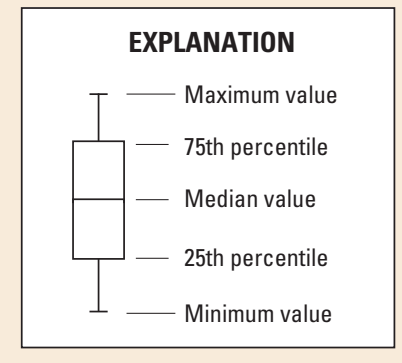



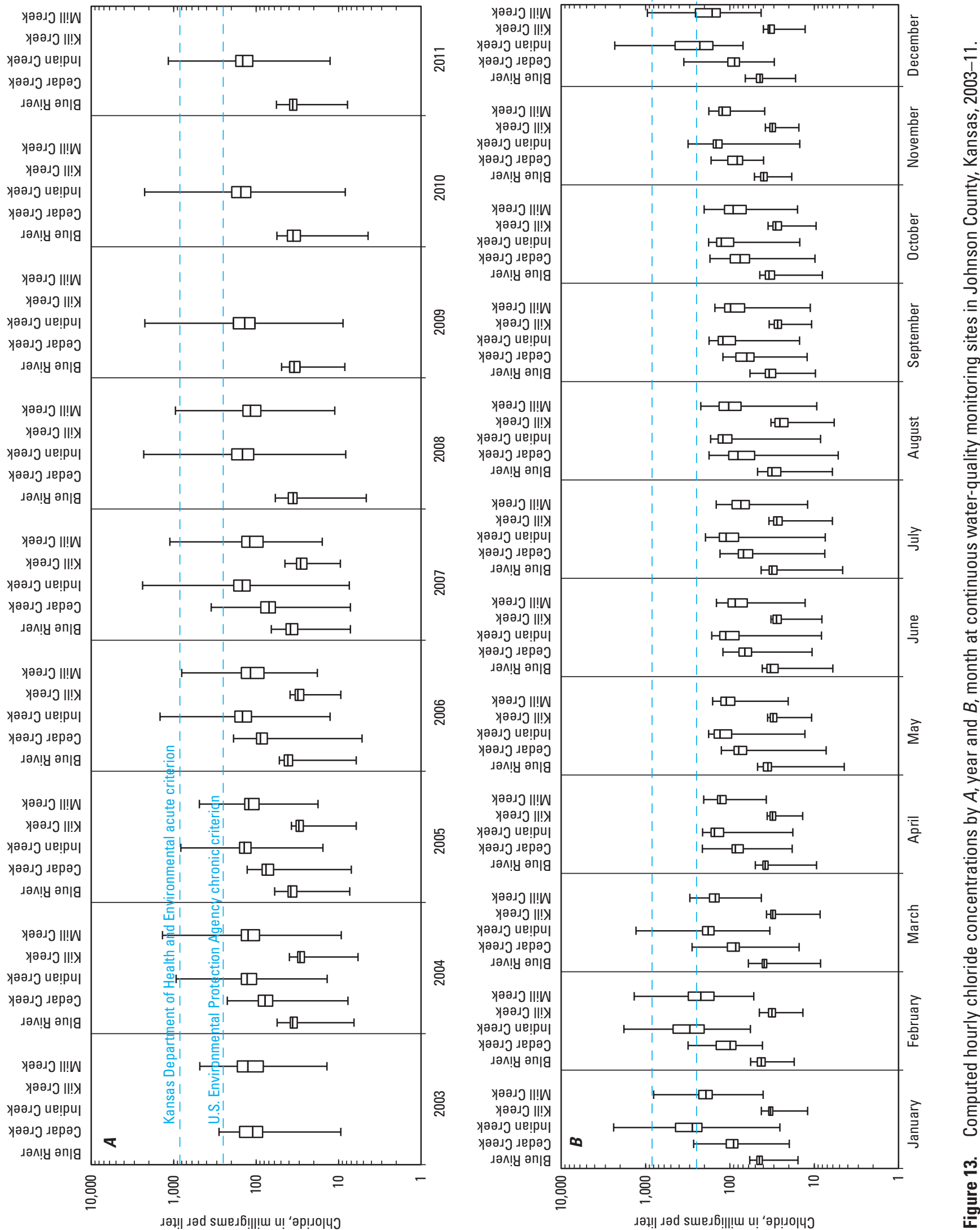


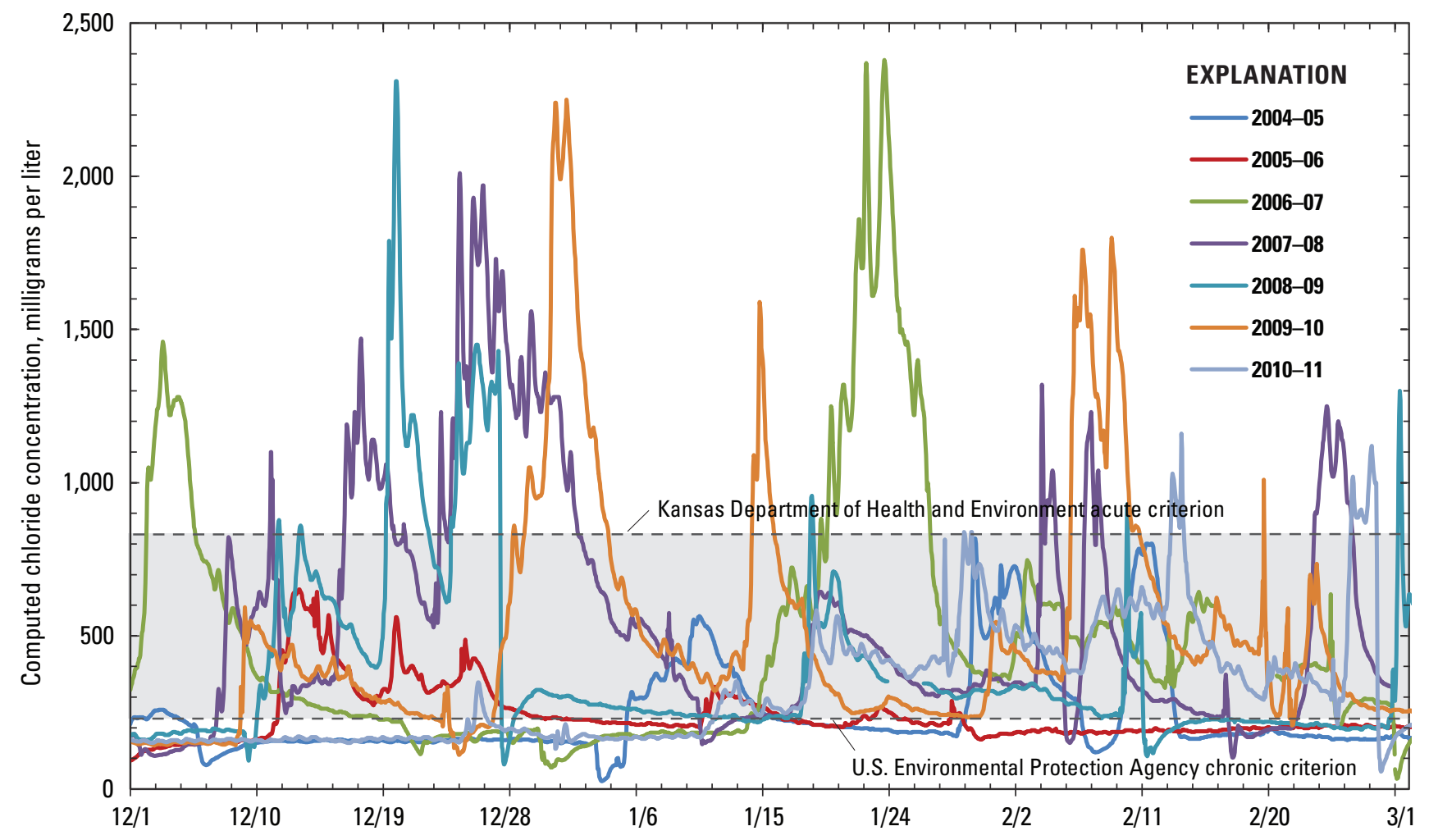

Figure 14. Computed hourly chloride concentrations at the Indian Creek monitoring site, Johnson County, Kansas, during December, January, and February, 2004-11.

periods for each site, the USEPA-recommended ecoregion criterion was exceeded 30 (Indian Creek) to 50 (Blue River) percent of the time (fig. $8 F$ ).

Changes in turbidity can occur on a daily basis and in response to changing streamflow. In Johnson County streams, for example Mill Creek, diel turbidity fluctuations can occur during stable base flow but is not always evident (fig. 9, $A 2$ ). Loperfido and others (2010) attributed diel turbidity cycling in Iowa streams to bioturbation, or resuspension of streambed sediment caused by nocturnal fishes. Turbidity increases rapidly in response to storm runoff. In the Mill Creek watershed, four consecutive runoff events in June 2008 (fig. 9, B2) resulted in rapid increases in turbidity (and sediment-associated constituents) which peaked and persisted at different magnitudes. Differences among storms may be caused by changing sediment sources, differences in rainfall intensity, and differences in the length of time since the last runoff occurrence.

Sediment in stream water can reduce light penetration, smother benthic habitats, clog gill structures in fish, reduce photosynthesis, and interfere with water-treatment equipment (Devlin and McVay, 2001). Sediment originates primarily from erosion of surface soils and stream channels and is transported primarily during stormflow. Suspended sediment, particularly sediment composed of fine material (silt and clay), provides attachment sites allowing accumulation and transport of nutrients, pesticides, and bacteria; therefore, an understanding of sediment occurrence and transport in streams leads to increased understanding of occurrence and transport of other related constituents. Suspended-sediment concentrations and loads can increase in urban or urbanizing areas because of exposed soils at construction sites (Lee and others, 2009), or increased stream channel erosion caused by increased streamflow velocities contributing to more streambed and bank erosion, and lack of riparian vegetation for protecting soils from erosion. Urban stream channels usually have increased streambed scour and bank erosion compared to channels in undeveloped areas (Hession and others, 2003) and also may have higher suspended sediment concentrations (Walters and others, 2003), which can have negative effects on aquatic ecosystems (Waters, 1995). Urbanization affects sediment supply and transport differently during construction and postconstruction phases (Paul and Meyer, 2001). During construction, erosion of exposed soils leads to larger sediment loads (Leopold, 1968). After construction, increases in impervious surface lead to decreased sediment from surface soils and increased channel-bank erosion (Leopold and others, 2005).

Regression models for suspended-sediment concentration (SSC) use turbidity as the single explanatory variable, and were among the best models with the least uncertainty as indicated by $R^{2}$ ) values equal to or greater than 0.93 (fig. $4 B$ ) and other model diagnostic statistics (Rasmussen and others, 2008). In this report SSC is used to quantify concentrations of suspended solid-phase material in water rather than total suspended solids (TSS), which is often used in regulatory applications such as TMDLs and NPDES permits. Although the terms 


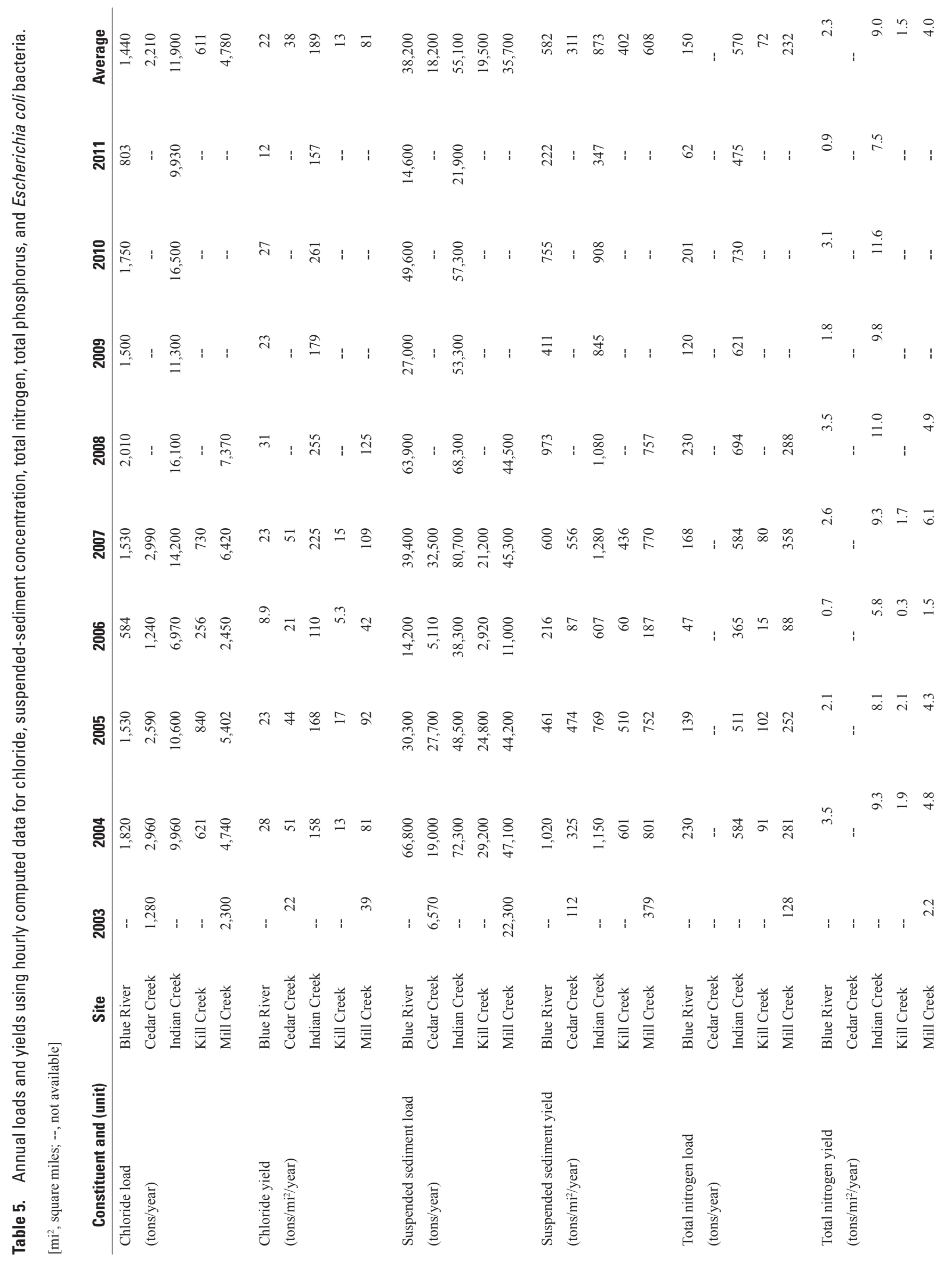




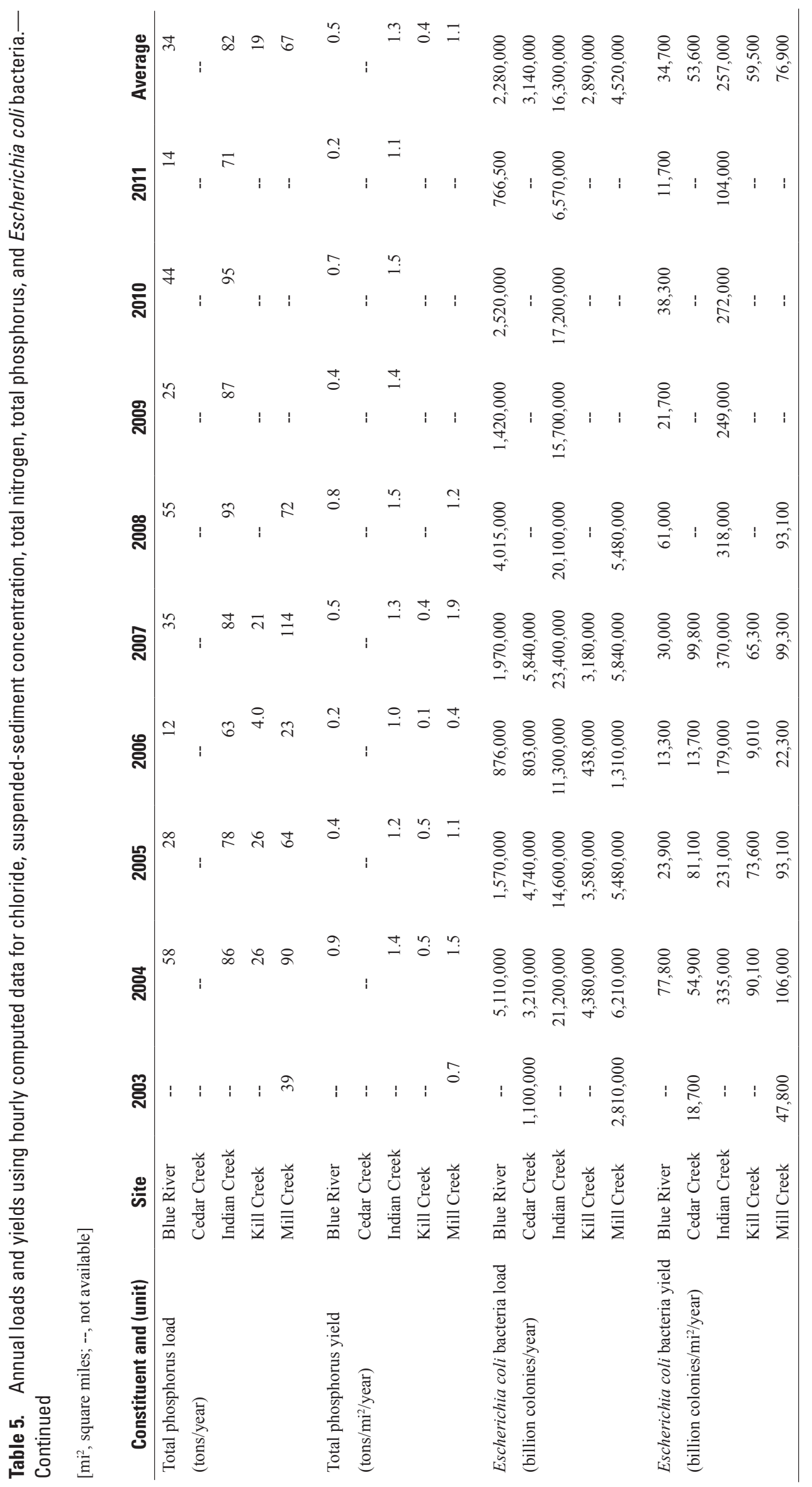


are sometimes used interchangeably, the laboratory analytical methods differ and may produce considerably different results, particularly when samples contain sand-sized material (Gray and others, 2000). The SSC method is preferred for quantifying solids in natural water samples because it has been determined to be more reliable than the TSS method, which was originally designed for analysis of wastewater samples (Gray and others, 2000).

Computed hourly SSC ranged from $1 \mathrm{mg} / \mathrm{L}$ annually at most sites except the Blue River to $8,400 \mathrm{mg} / \mathrm{L}$ at Cedar Creek in March 2007 (table 3, fig. 16, $A$ and $B$ ). The highest median SSC conditions were recorded in the Blue River every year that was monitored (2004-11, fig. 16). Median annual $\mathrm{SSC}$ in the Blue River (ranging from $19 \mathrm{mg} / \mathrm{L}$ to $42 \mathrm{mg} / \mathrm{L}$, table 3) was at least double that of all other sites annually except in 2005 and 2006 when Blue River median SSC was just 15 percent and 40 percent higher, respectively, than Mill Creek median SSC (table 3). However, the highest average annual streamflow-weighted concentration during the study period was in Mill Creek (652 $\mathrm{mg} / \mathrm{L})$, followed by the Blue River $(597 \mathrm{mg} / \mathrm{L})$, and then Indian Creek (536 mg/L; table 6). The Mill Creek watershed has undergone rapid development that likely contributed to higher sediment concentrations. High sediment concentrations in Blue River, a watershed that is mostly rural and not developing as rapidly as Mill Creek, may be because there are no large impoundments trapping sediment (Lee and others, 2010). Most of the time, the lowest sediment concentration was recorded at the Indian Creek site because most of the streamflow at this site originated from treated WWTF discharges just upstream.

The Blue River suspended-sediment model was updated in 2010 (Graham and others, 2010) which resulted in computed concentrations that are higher than those previously published during 2005-06 (Rasmussen and other, 2008). Discrete samples used to develop the Blue River model had higher sediment concentrations during low turbidity compared to other sites. Computed sediment concentrations during low turbidity may be slightly overestimated.

Annual suspended-sediment loads were always largest at the Indian Creek site, which carries the largest streamflow volume. The largest annual sediment load in Indian Creek was recorded in 2007 (fig. 16, table 5), which was not the year with the largest total streamflow volume (2008, table 4), likely because a sensor malfunction prevented turbidity data from being collected during a large streamflow event in July 2008. The largest recorded load event in Indian Creek occurred in early May 2007 (fig. 17E) when about 20,000 tons of sediment (about 25 percent of the total annual load) were transported during a period of 2.25 days. A simultaneous load event was recorded in Kill Creek, when about 75 percent of the total annual sediment load (about 15,000 tons) was transported (fig. 17E). Each of the other watersheds also experienced runoff events when a large percentage of the annual load was transported. In the Blue River, the largest annual streamflow volume and sediment load was recorded in 2004, and two separate events during the spring (early March and mid-May) each transported about 20,000 tons of sediment (fig. 17B), together accounting for about 60 percent of the total annual load that year (about 67,000 tons, table 5). In 2010, a series of runoff events in the Blue River during a 10-day period in June carried about 60 percent (30,000 tons) of the total annual sediment load (fig. $17 \mathrm{H}$, table 5). In Cedar Creek, the largest single sediment load event was recorded in early June 2005, when about 13,000 tons (about 45 percent of the annual load) were transported (fig. 17C).

Suspended-sediment yield among sites monitored was largest for Indian Creek, the most urban site, in every year (table 5). The average annual sediment yield during 2004-07, when monitors were operating at all five sites, ranged from 950 tons $/ \mathrm{mi}^{2}$ in Indian Creek (98.3 percent urban, table 5, fig. 15) and 627 tons $/ \mathrm{mi}^{2}$ in Mill Creek (67.4 percent urban), to 402 tons $/ \mathrm{mi}^{2}$ at Kill Creek, the least urban site (16.7 percent). Sediment yields generally increased as percent impervious surface increased (fig. 11C). Comparing smallest and largest annual suspended-sediment yields during 2004-07, Indian Creek varied by a factor of 2 (607 tons $/ \mathrm{mi}^{2}$ in 2006 and 1,280 tons/ $\mathrm{mi}^{2}$ in 2007), and Kill Creek varied by a factor of 10 (60 tons $/ \mathrm{mi}^{2}$ in 2006 and 601 tons $/ \mathrm{mi}^{2}$ in 2004, table 5, fig. 15). Suspended-sediment yield in 2006, the driest year that monitors operated at all sites, was particularly low in Kill Creek because soils and vegetation in rural watersheds can absorb more rainfall than impervious surfaces in urban watersheds. Lee and others (2009) hypothesized that larger sediment loads in the urban Indian Creek watershed could be attributed to current and legacy sediment from construction projects and accelerated stream-channel erosion.

\section{Nutrients}

Nutrients, including various forms of nitrogen and phosphorus, are essential for proper plant and animal growth, but in excess can lead to eutrophication, algal blooms, fish kills, low dissolved oxygen, taste and odor problems, and other disruptions in aquatic ecosystems. Runoff from both urban and nonurban sources contributes to nutrient concentrations in streams. Typical nutrient sources include municipal wastewater discharge, fertilizers, and runoff from livestock operations (Masters, 1991). In addition, natural background concentrations of total nitrogen and total phosphorus in headwater streams within the study area have been estimated to be 0.15 to $0.30 \mathrm{mg} / \mathrm{L}$ and $0.06 \mathrm{mg} / \mathrm{L}$ or greater, respectively (Smith and others, 2003). Kansas has no numerical water-quality criteria for total nitrogen or total phosphorus but has set a goal of reducing export of these nutrients from the State by 30 percent (Kansas Department of Health and Environment, 2004). USEPA ecoregion IX, level III subecoregion 40 (Central Irregular Plains that includes Johnson County) recommended criteria are $0.855 \mathrm{mg} / \mathrm{L}$ total nitrogen and $0.0925 \mathrm{mg} / \mathrm{L}$ for total phosphorus (U.S. Environmental Protection Agency, 2003). 

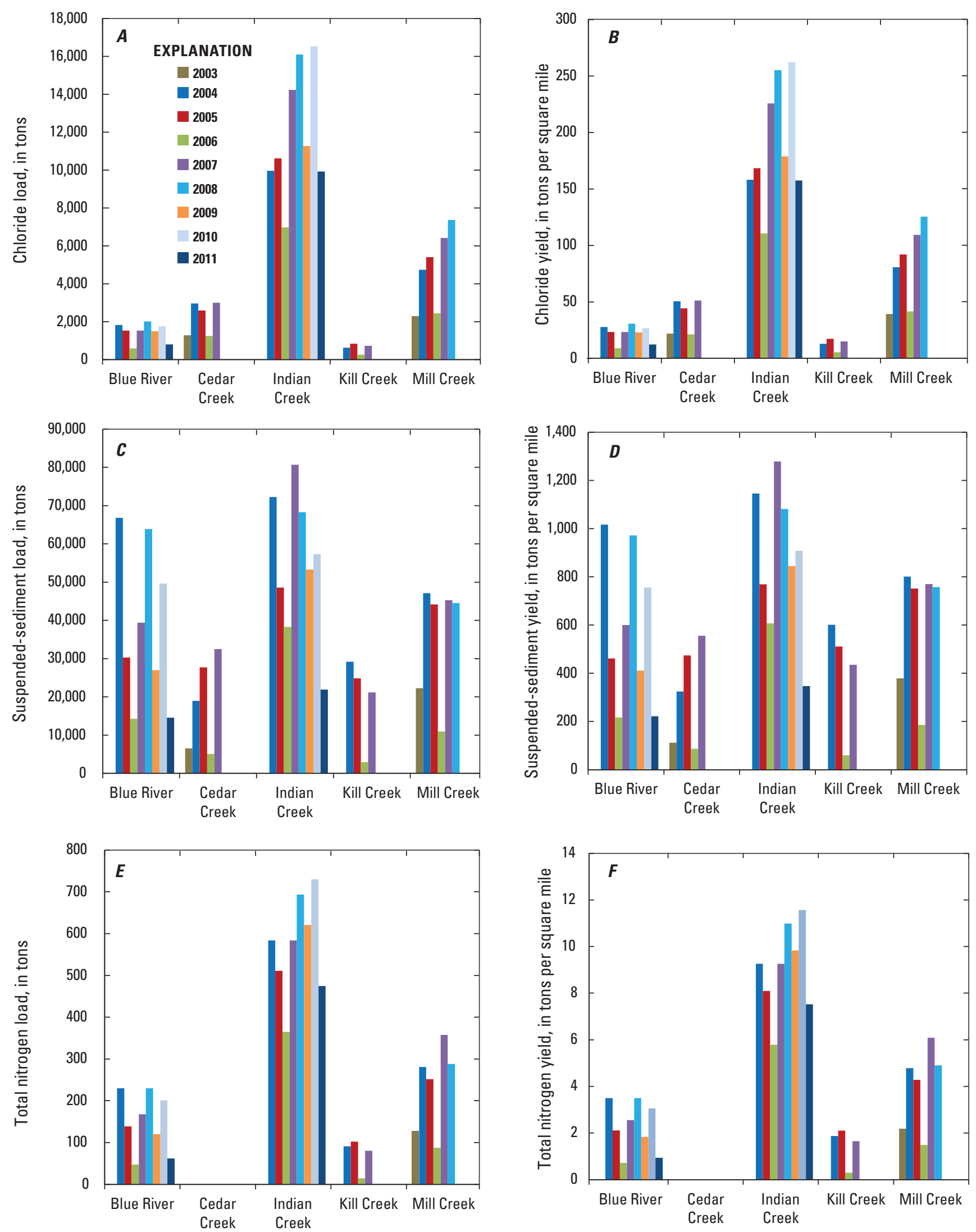

Figure 15. Annual loads and yields using hourly computed data for chloride $(A, B)$; suspended sediment $(C, D)$; total nitrogen $(E, F)$; total phosphorus $(G, H)$; and Escherichia coli bacteria $(I, J), 2003-11$. 

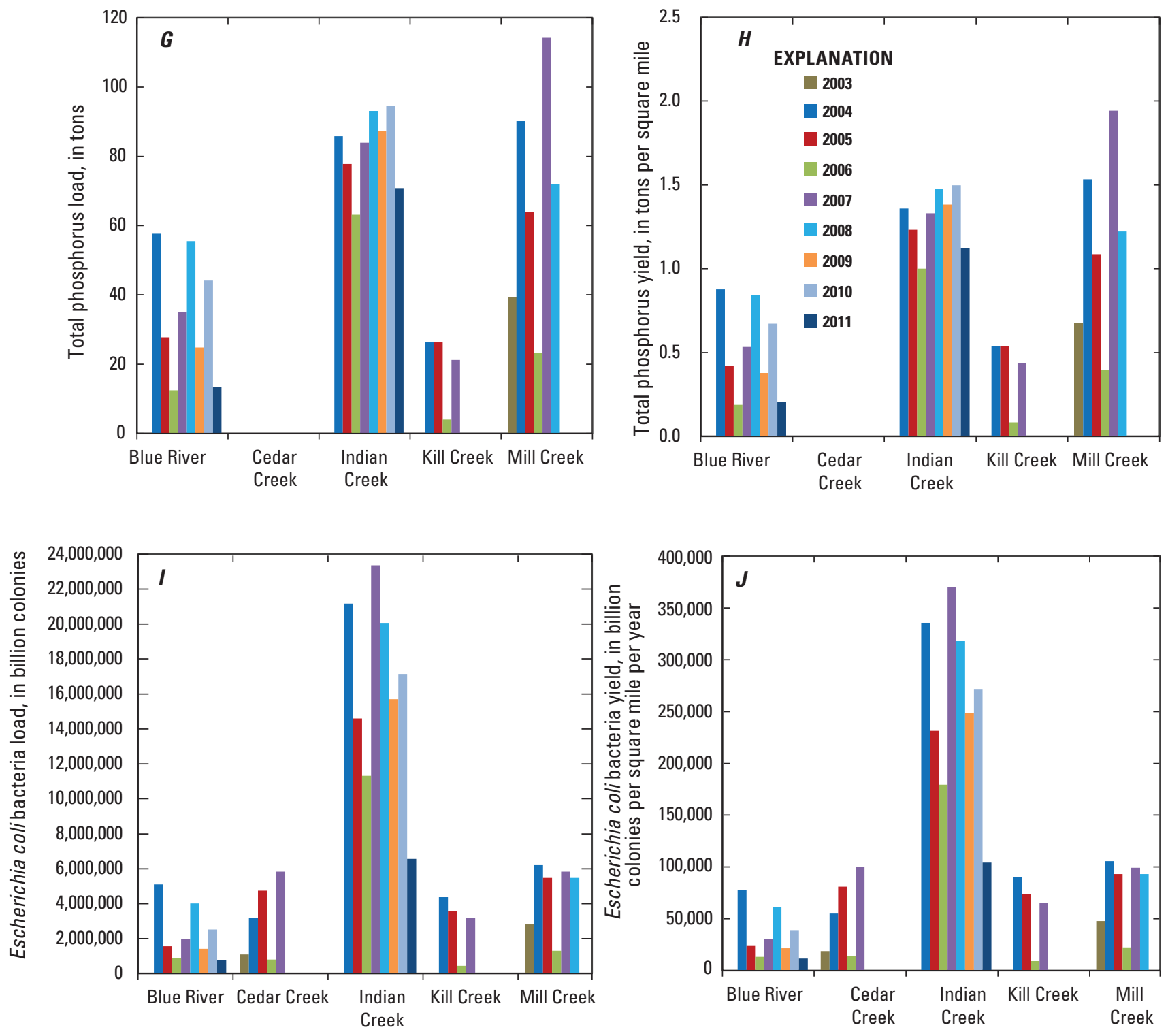

Figure 15. Annual loads and yields using hourly computed data for chloride $(A, B)$; suspended sediment $(C, D)$; total nitrogen $(E, F)$; total phosphorus $(G, H)$; and Escherichia coli bacteria (I, J), 2003-11.-Continued

Computed hourly total nitrogen and total phosphorus concentrations during the study period generally were highest at the Indian Creek site (figs. 18 and 19). Median annual total nitrogen $(\mathrm{TN})$ concentrations in Indian Creek (ranging from $7.1 \mathrm{mg} / \mathrm{L}$ to $7.9 \mathrm{mg} / \mathrm{L}$ ) were about 3 times higher than median annual TN concentrations in Mill Creek (ranging from $2.2 \mathrm{mg} / \mathrm{L}$ to $2.3 \mathrm{mg} / \mathrm{L}$ ), and at least 7 times higher than median annual TN concentrations in Blue River and Kill Creek (less than $1.0 \mathrm{mg} / \mathrm{L}$, table 3). Streamflow-weighted TN concentrations during the study period were highest in Indian Creek $(5.6 \mathrm{mg} / \mathrm{L})$ and Mill Creek (4.2 mg/L, table 6). Median annual total phosphorous (TP) concentrations in Indian Creek (ranging from $1.3 \mathrm{mg} / \mathrm{L}$ to $1.54 \mathrm{mg} / \mathrm{L}$ ) were at least 3 times higher than median annual TP concentrations in Blue River and Kill and Mill Creeks (table 3). Streamflow-weighted TP concentrations were highest in Mill Creek $(1.2 \mathrm{mg} / \mathrm{L})$ then Indian Creek $(0.8 \mathrm{mg} / \mathrm{L}$, table 6$)$. The largest TN loads and yields were recorded in Indian Creek, followed by Mill Creek (fig. 15, table 5). TP loads and yield were similar for Indian and Mill Creeks except during 2006 when they were largest in Indian Creek (table 5).

The relative importance of nutrient contributions from wastewater treatment facilities were quantified for Blue River and Indian Creek, both sites where WWTF discharges are located near the monitoring sites (fig. 1). Because the WWTF discharges downstream from the monitoring site on the Blue River, loads originating from the wastewater were added to loads computed at the monitoring site to determine 


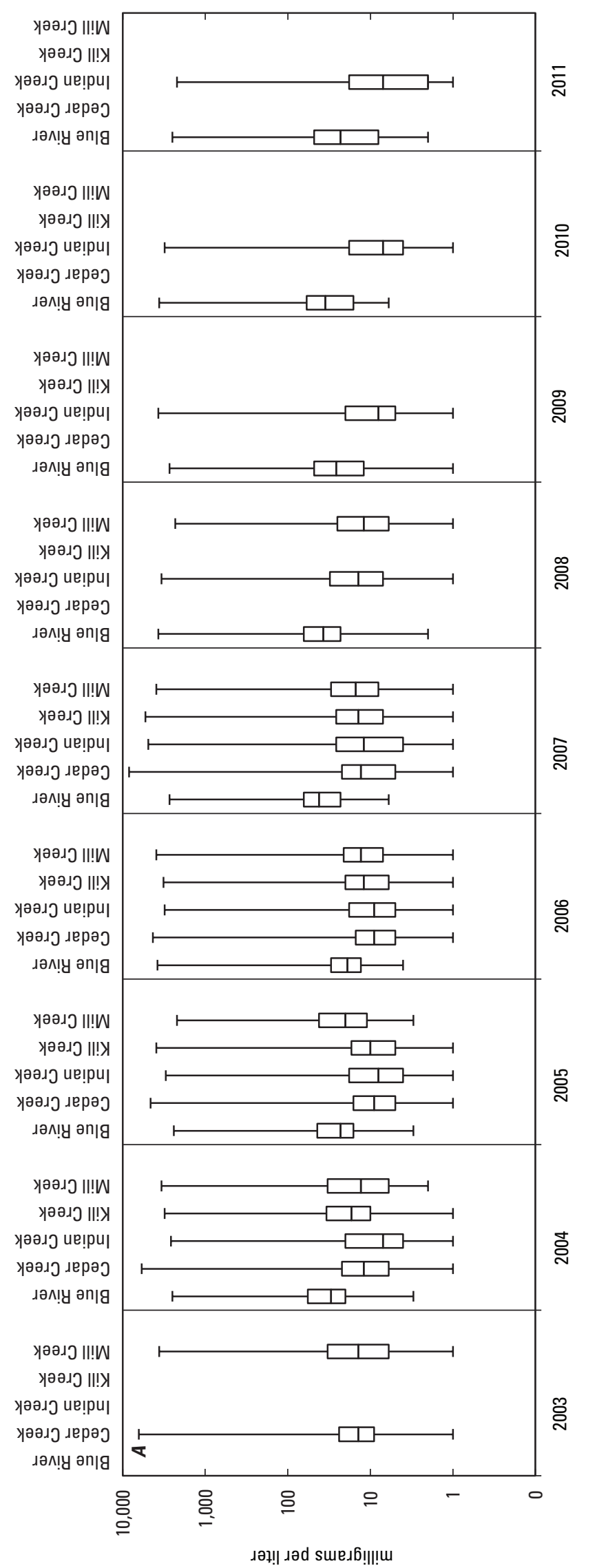

u! ‘uo!̣eдұนәэиоэ ұuәแ! pәs-pәpuədsns

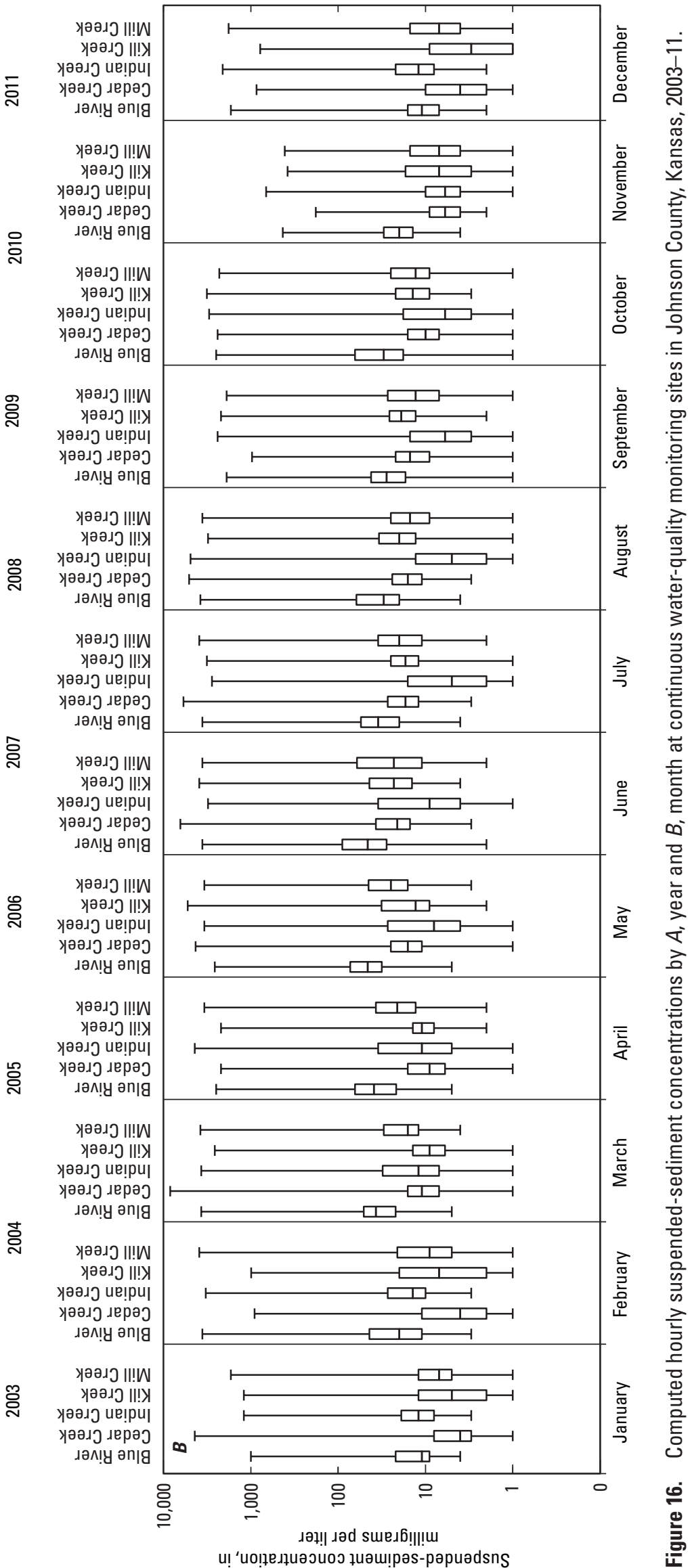




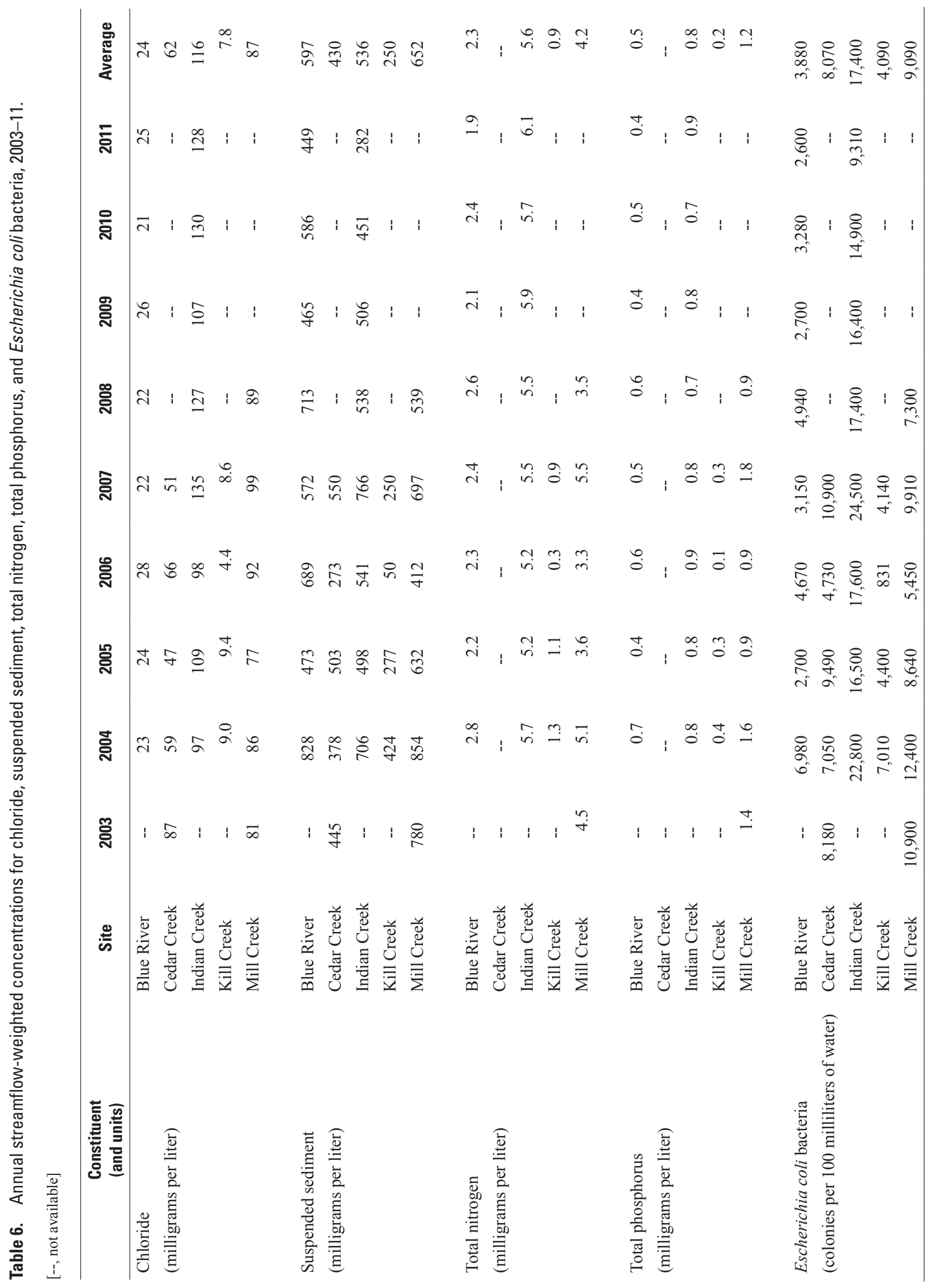




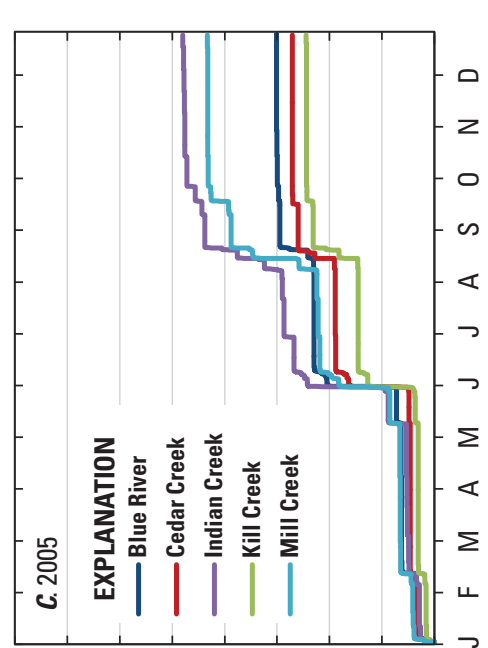

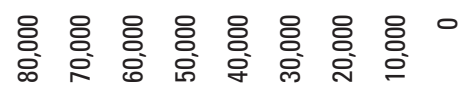

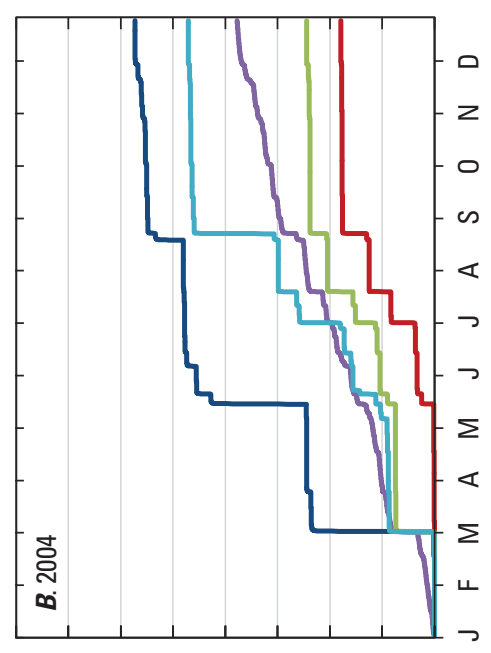

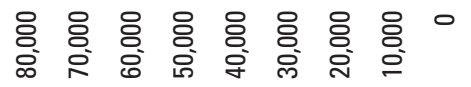

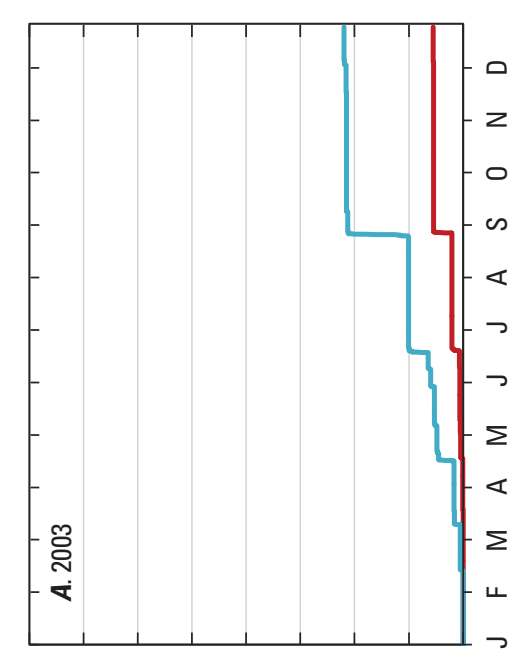

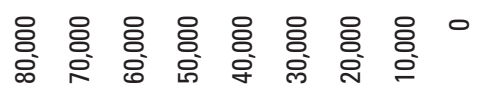

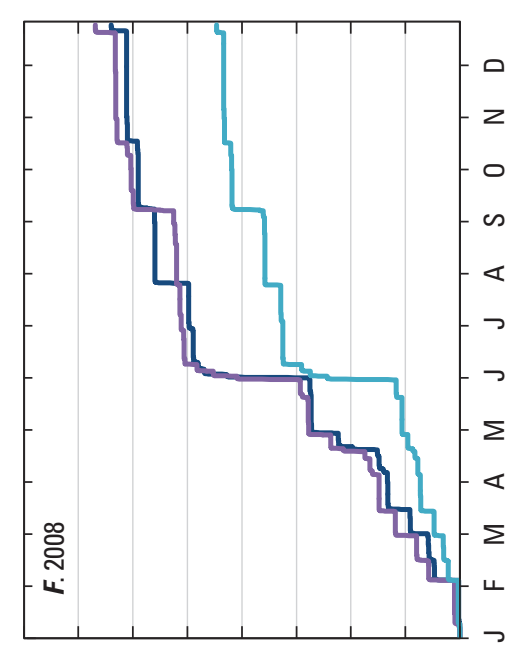

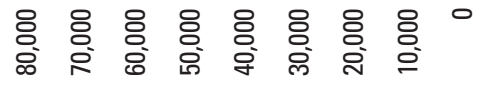

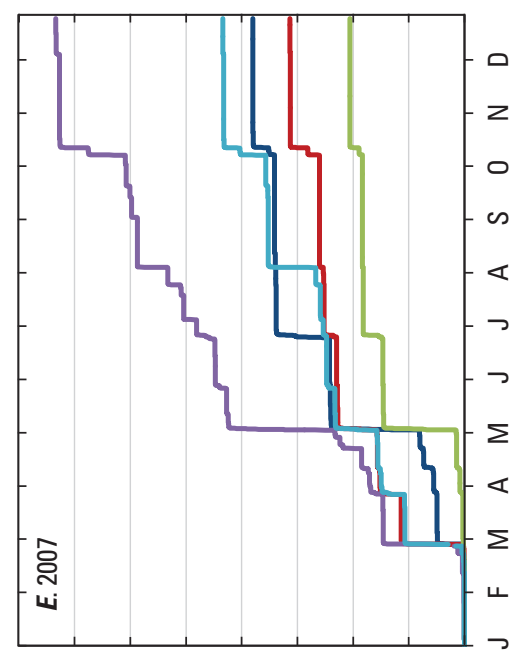

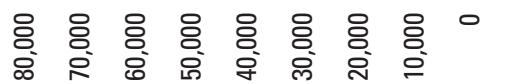

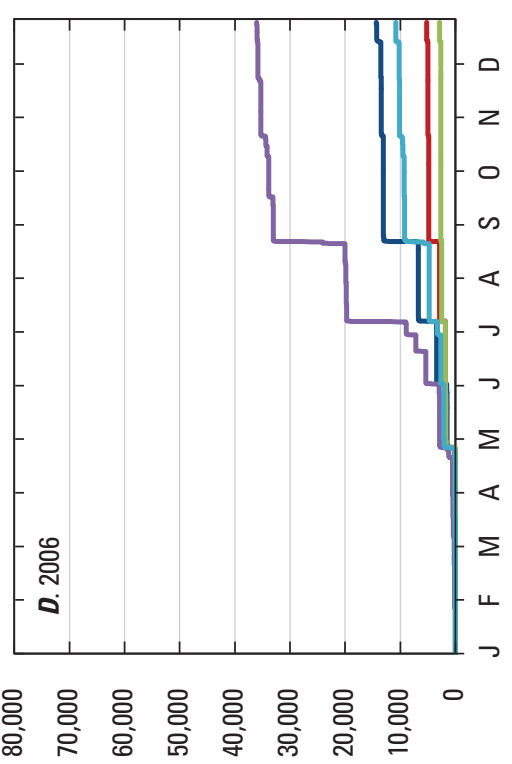

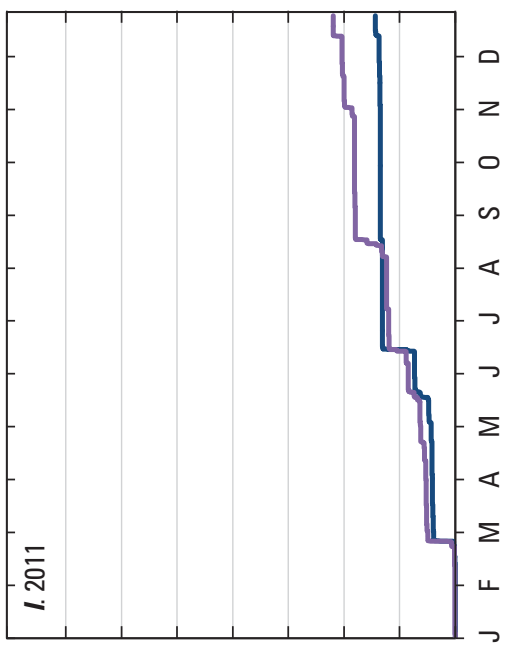

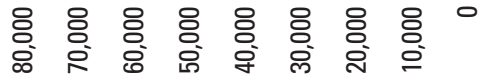
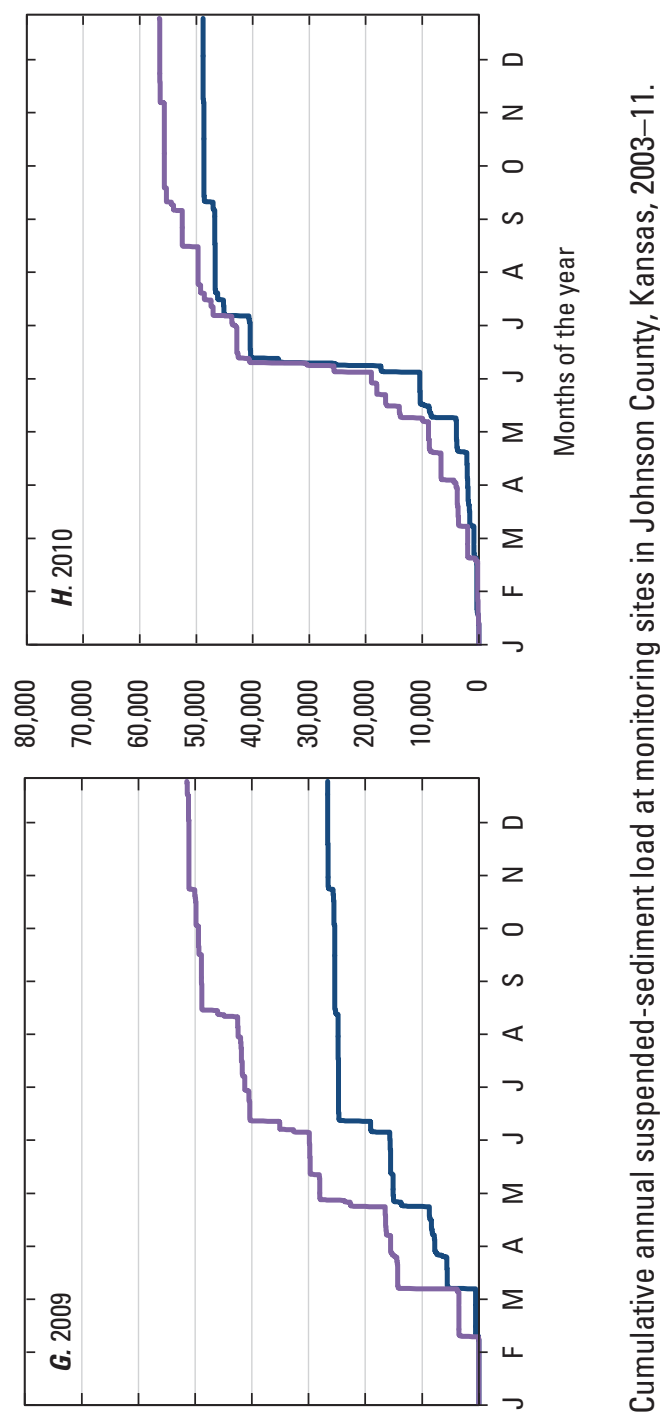

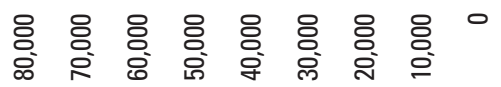




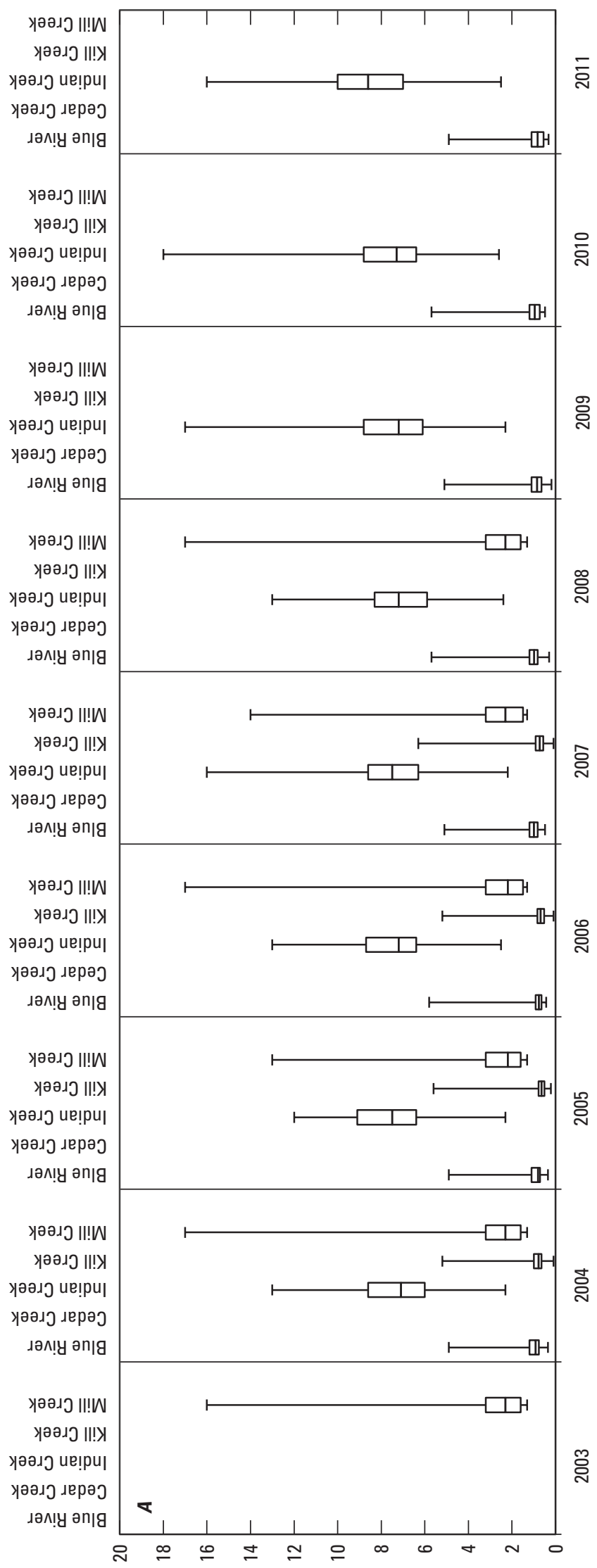

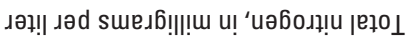

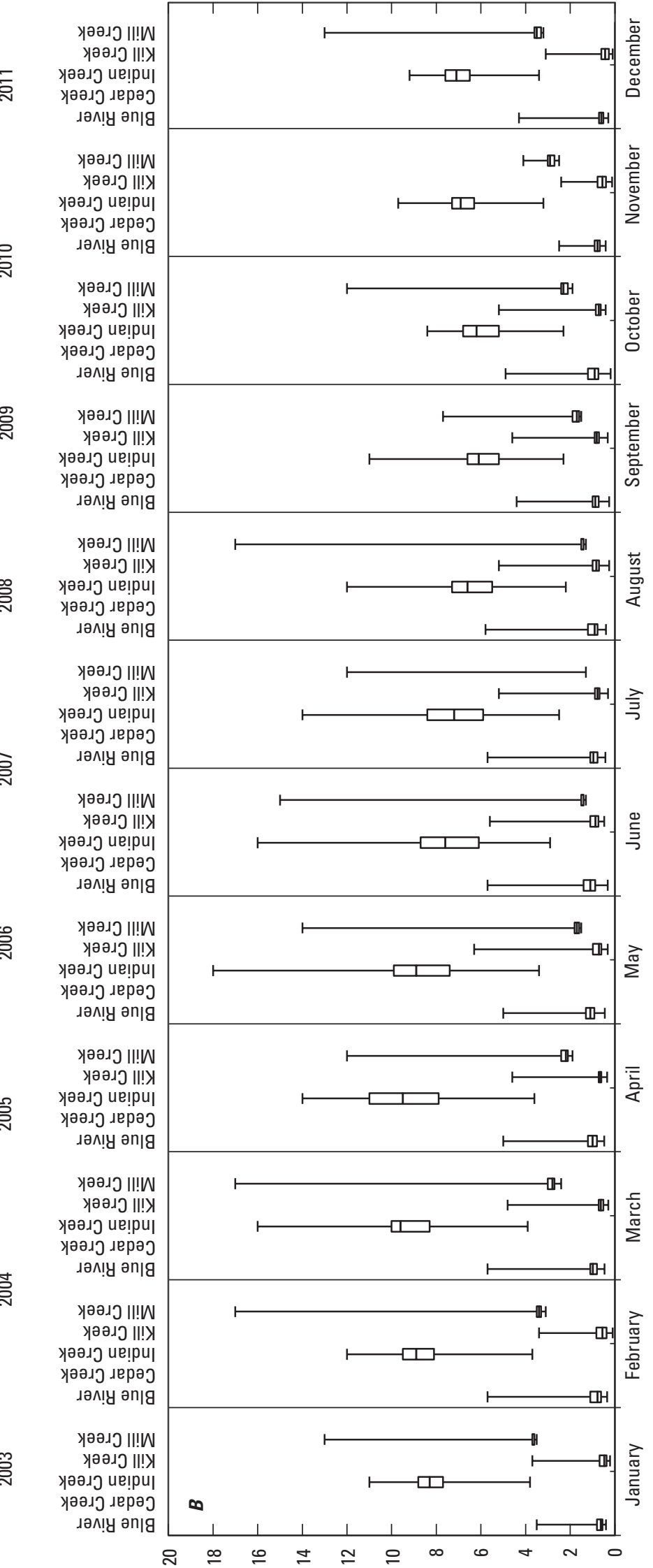

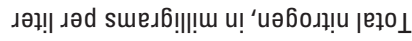




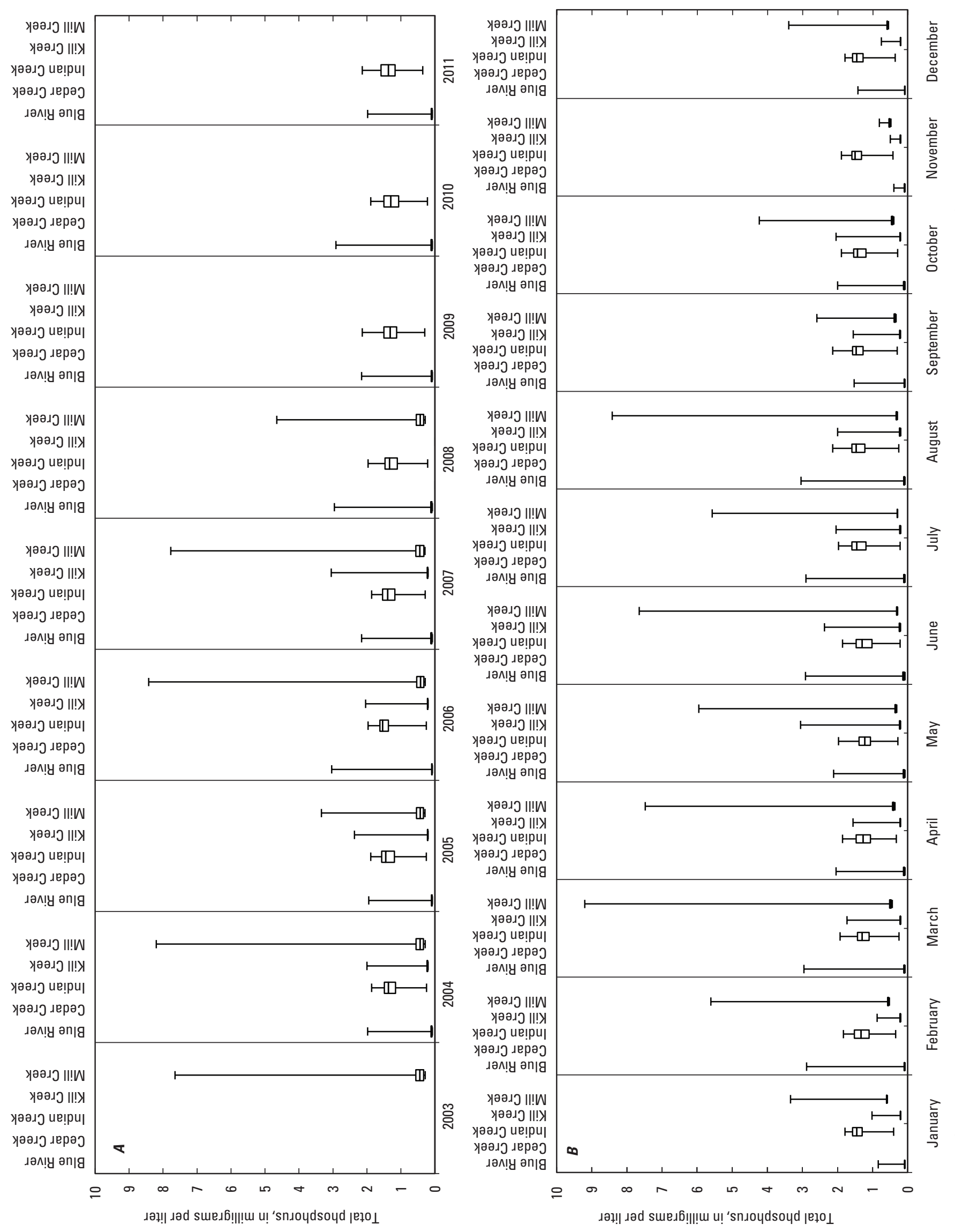

章 
percent contribution to total load. Annual streamflow volume originating from WWTF discharges ranged from 8 to 19 percent in the Blue River and 17 to 31 percent in Indian Creek (fig. 20A). Annual percent contribution of total nitrogen in the Blue River from WWTF discharges ranged from 19 percent ( 50 tons) in 2010 to 60 percent (60 tons) in 2006 (fig. 20B). Upgrades to the Blue River WWTF in 2008 decreased nitrogen concentrations from effluent discharges (Graham and others, 2010). Larger load contributions from WWTF discharges in years after the upgrade are attributed to larger streamflow volumes during those years. Annual percent contribution of total nitrogen in Indian Creek from WWTF discharges ranged from 35 percent (250 tons) in 2010 to 93 percent (300 tons) in 2006 (fig. 20B). Large percent contributions in both watersheds were recorded during 2006 and 2011 when less precipitation occurred, decreasing contributions from runoff.

Annual percent contribution of total phosphorus in the Blue River from WWTF discharges ranged from 18 percent (5 tons) in 2010 to 46 percent (10 tons) in 2006 (fig. 20C). Annual percent contribution of total phosphorus in Indian Creek from WWTF discharges ranged from 39 percent (about 40 tons) in 2010 to more than 100 percent (about 75 tons) in 2006 (fig. 20C). Larger total phosphorus load in Indian Creek wastewater discharge than at the downstream monitoring site in 2006 (when the lowest streamflow conditions occurred) may be a result of uncertainty in the load estimation or could be phosphorus uptake by plant and animal life within the distance between the WWTF discharges and the monitoring sites, with less flushing from stormwater runoff.

\section{Indicator Bacteria}

E. coli is a type of bacteria commonly used as an indicator of pathogens in surface water. Indicator bacteria are used to evaluate the sanitary quality of water and its use as a public water supply and for recreational activities such as swimming, wading, boating, and fishing (American Public Health Association and others, 1995). The presence of E. coli indicates the possible presence of pathogens found in feces of warm-blooded animals (Dufour, 1977). These indicator bacteria and pathogens may cause human diseases ranging from mild diarrhea to respiratory disease, septicemia, meningitis, and polio (Dufour, 1977).

Kansas water-quality criteria for $E$. coli bacteria require stream sites to be classified and regulated according to designated use and accessibility. Most segments of the Blue River and Cedar and Mill Creeks have been designated as Class $\mathrm{C}$, indicating that primary contact recreation is not open to and made accessible to the public. Most segments of Kill Creek are Class B, indicating that primary contact recreation is accessible to the public with landowner permission. Designated uses for Indian Creek have not been determined. Primary contact recreational use criteria for $E$. coli state that for the three use classifications of water, a geometric mean of 5 samples collected during separate 24 -hour periods within a 30-day period cannot exceed 160, 262, and 427 colony-forming units per $100 \mathrm{~mL}$ of water from April through October each year. From November through March primary contact criteria for E. coli are 2,358 or 3,843 col/100 mL for the three use classes (Kansas Department of Health and Environment, 2012). Geometric means were not applied in this report because the data used are continuous rather than five discrete samples collected during separate 24-hour periods within 30-day periods, as described by the criteria. A comparison to the actual criteria values, however, is considered meaningful when evaluating continuous data.

All regression models for indicator bacteria included turbidity as the single explanatory variable (fig. $4 C$, Rasmussen and others, 2008 and Graham and others, 2010). Indicator bacteria have been shown to be closely related to sediment because bacteria adsorb to suspended sediment particles such as silt and clay (Kittrel and Furfari, 1963), and because the magnitude of suspended-sediment concentration often is proportional to turbidity (Rasmussen and others, 2009b). The relation between turbidity and E. coli bacteria at the Indian Creek site is different from the other sites (fig. $4 C$ ). The slope is less and the $y$-intercept is greater, indicating that at low turbidity values, $E$. coli densities at the Indian Creek site are higher relative to the other sites. Urban sources, such as leaking sewage lines or pet waste, may cause higher bacteria densities. In addition, the site is affected by wastewater discharges.

$E$. coli density at the urban Indian Creek site was usually the highest of the five monitoring sites with a median density that exceeded the primary contact criterion value but was less than the secondary contact criterion each year (fig. 21A). The Blue River and Cedar Creek sites had the lowest bacteria densities most of the time (fig. 21A). During 2008, when the precipitation and streamflow volume were largest, median density in Indian Creek was highest, and the probability of exceeding criteria was at or nearly 100 percent on numerous occasions (fig. 22A). By contrast, in the least urban stream, Kill Creek, during 2006 when less precipitation was received and annual streamflow volume was the lowest, probability of exceeding criteria generally was much lower throughout the year (fig. 22B). Streamflow-weighted $E$. coli density in Indian Creek during the study period was at least double the density of other sites, but decreased during the study period from an annual maximum of $24,500 \mathrm{col} / 100 \mathrm{~mL}$ in 2007 to a minimum of $9,310 \mathrm{col} / 100 \mathrm{~mL}$ in 2011 (table 6). Average annual bacteria load and yield in Indian Creek was more than three times any other site (table 5). Potential urban sources of bacteria in Indian Creek include leaking sewer lines, pet waste, wildlife, WWTF discharges and bypasses, and unauthorized discharges. Less than 1 percent of the total downstream Blue River and Indian Creek indicator bacteria load originated from WWTF discharges, except during 2006 when about 6 percent of the Indian Creek load originated from 

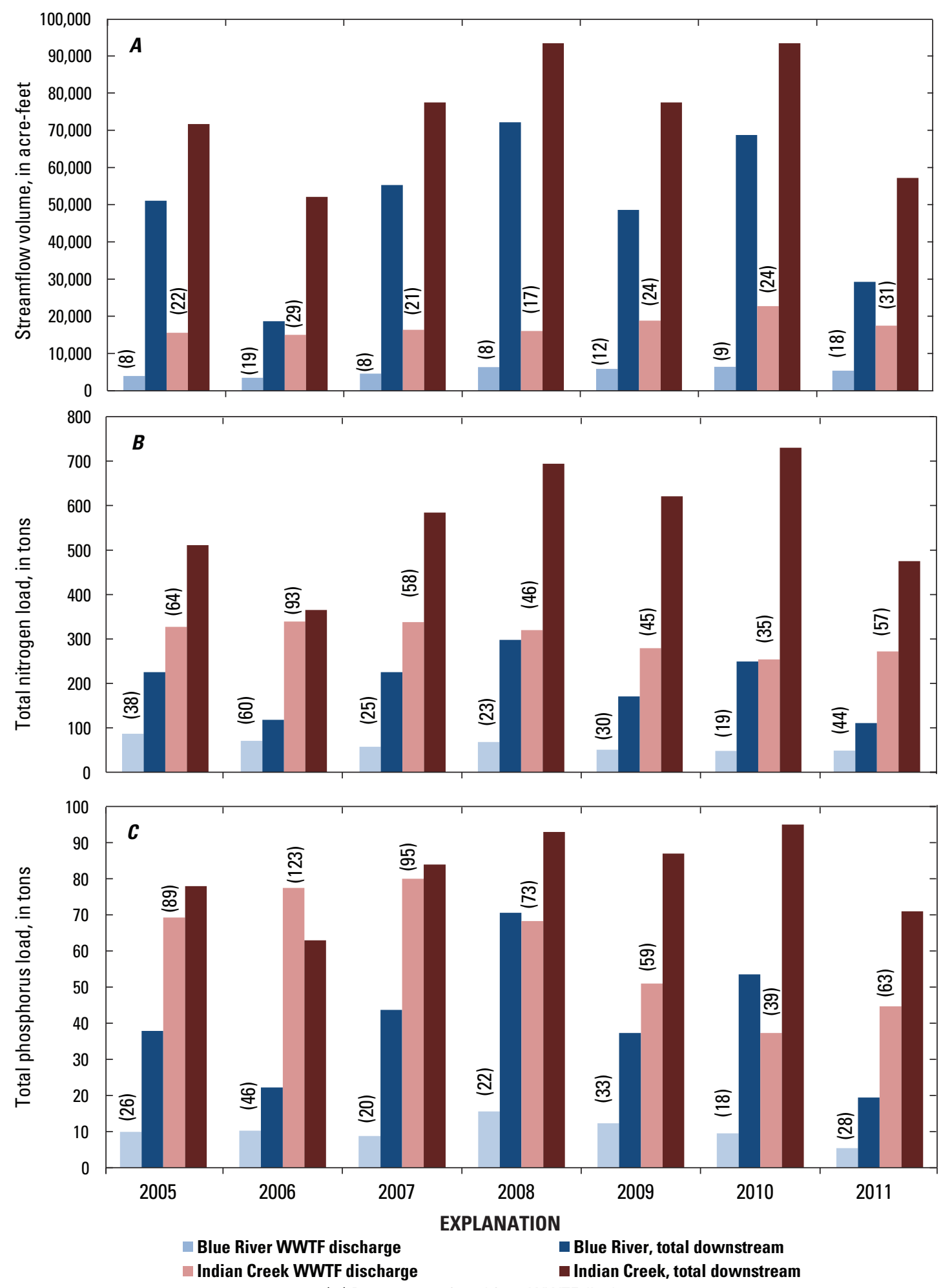

( ) Percentage of total from WWTF discharge

Figure 20. Annual $A$, streamflow volume; $B$, total nitrogen; and $C$, total phosphorus loads originating from wastewater treatment facility (WWTF) discharges compared to total loads in Blue River and Indian Creek, Johnson County, Kansas, 2005-11. 


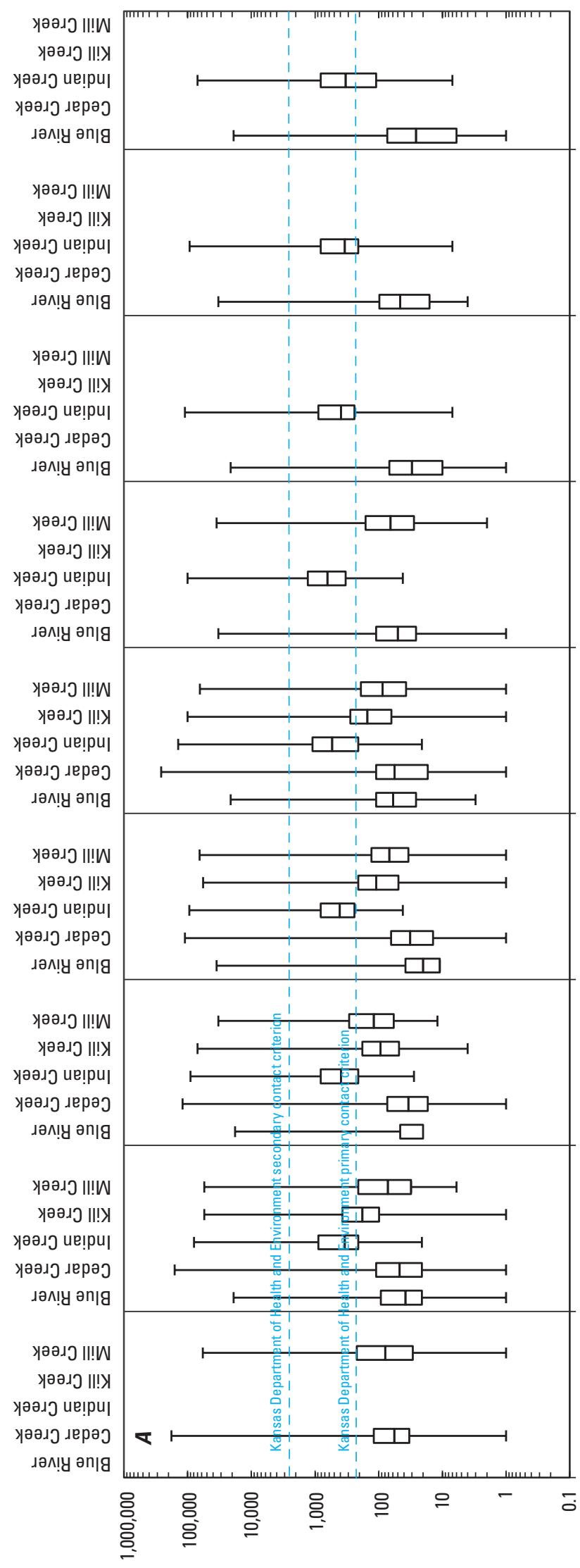

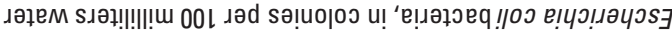

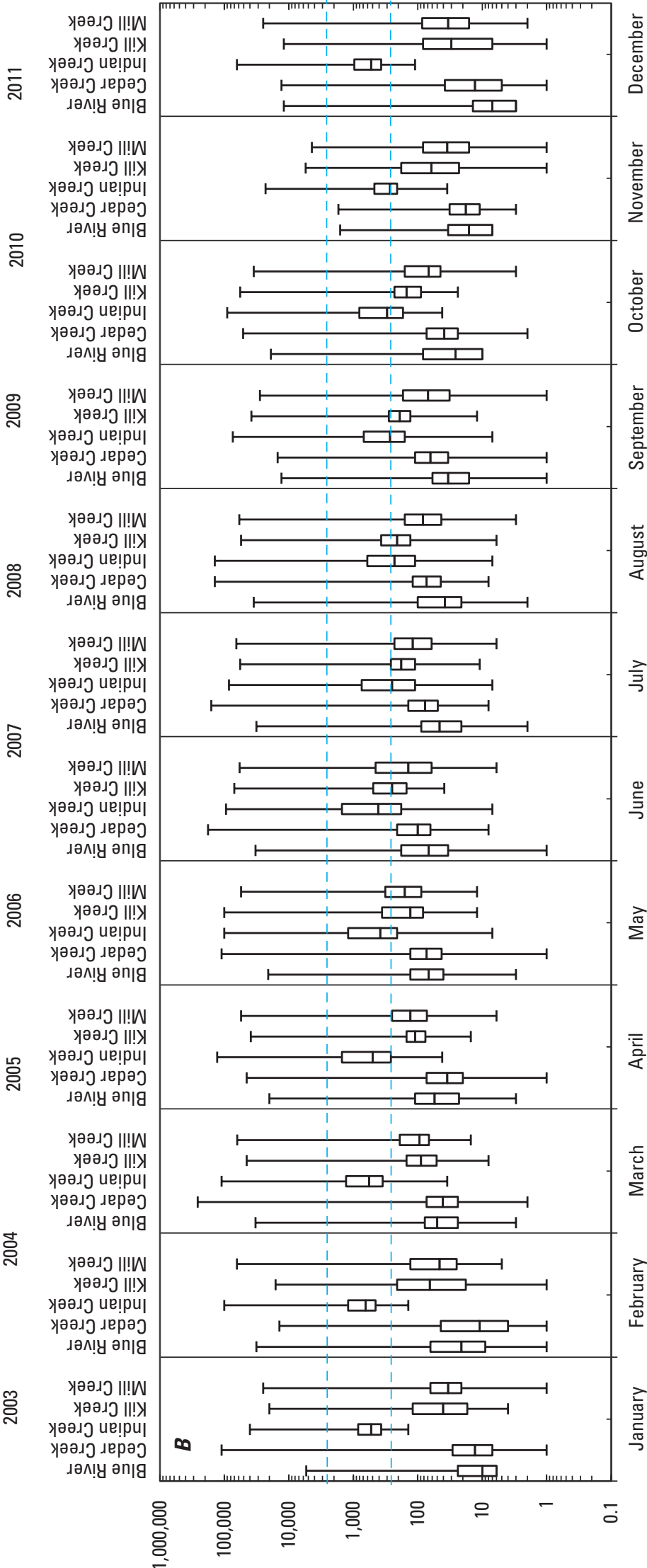

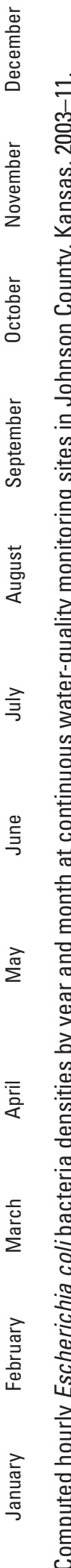

ำ 


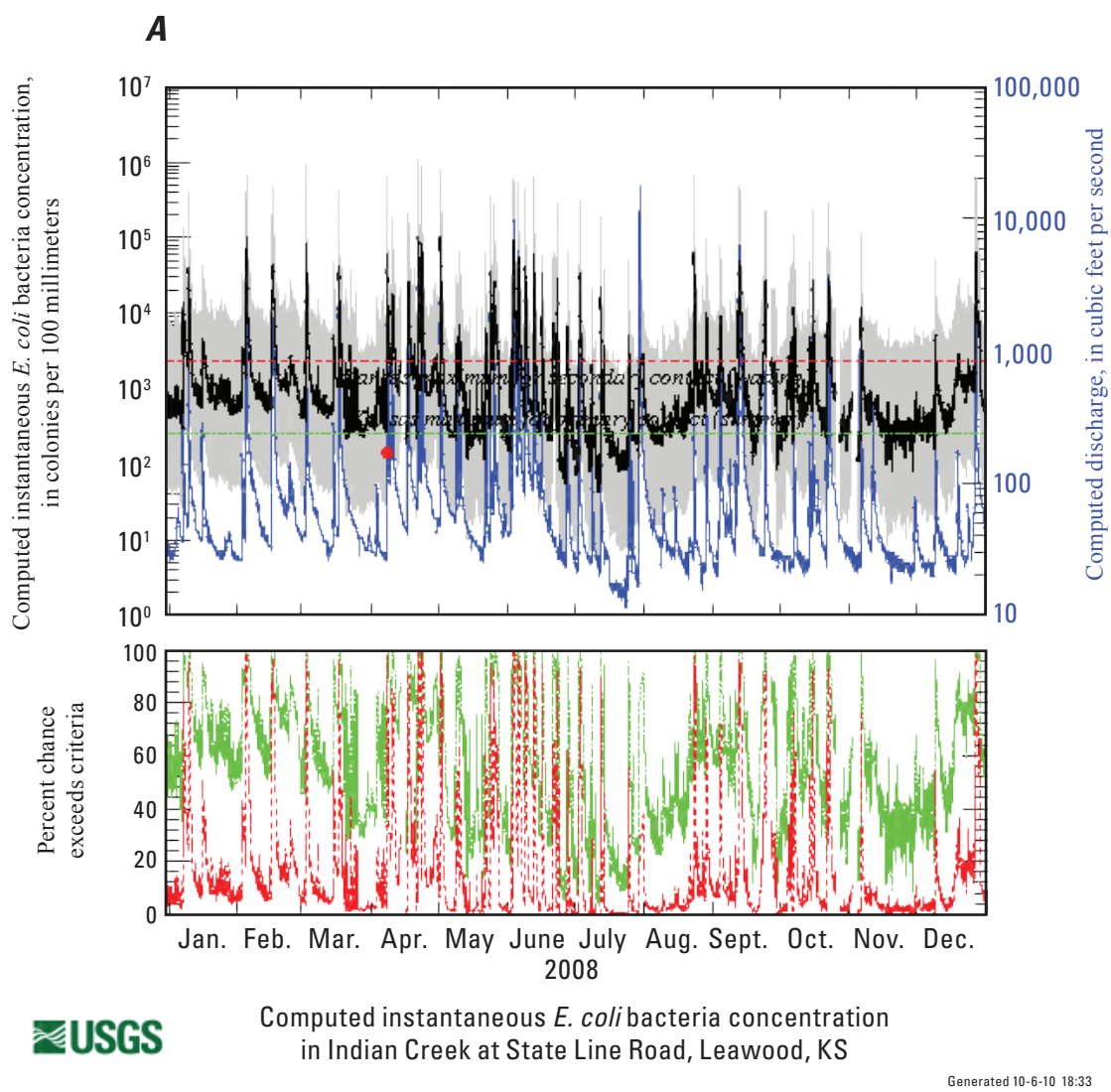

Source http://nrtwq.usgs.gov/ks

\section{EXPLANATION}

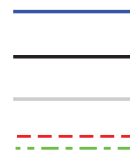

Discharge

Measured or computed water-quality constituent

90-percent predition interval for computed value

Water-quality criteria

Value obtained from discrete sampling and analysis

Figure 22. Computed hourly Escherichia coli (E. coli) bacteria density and probability of exceeding primary and secondary contact criteria at the $A$, Indian Creek (largest urban) monitoring site during 2008 and $B$, Kill Creek (smallest rural) monitoring site during 2006, Johnson County, Kansas.

wastewater (fig. 23). Fecal coliform bacteria were used in the evaluation of wastewater contributions during 2005-07 because WWTFs did not start collecting $E$. coli data until 2008. Urban sources of E. coli bacteria (such as leaky sewer lines, pet waste, wildlife, WWTF discharges and bypasses, or unauthorized dumping) generally contributed more than nonurban sources (such as livestock, leaky septic systems, and wildlife).

\section{Value of Continuous Water-Quality Monitoring}

Continuous water-quality monitoring provides a foundation for comprehensive evaluation and understanding of variability and loading characteristics in streams of Johnson County. Because several directly measured parameters (such as specific conductance and turbidity) are strongly correlated with particular constituents of interest (such as chloride, suspended sediment, nutrients, and fecal-indicator bacteria), regression models provide a valuable tool for evaluating variability and loading on the basis of computed continuous 


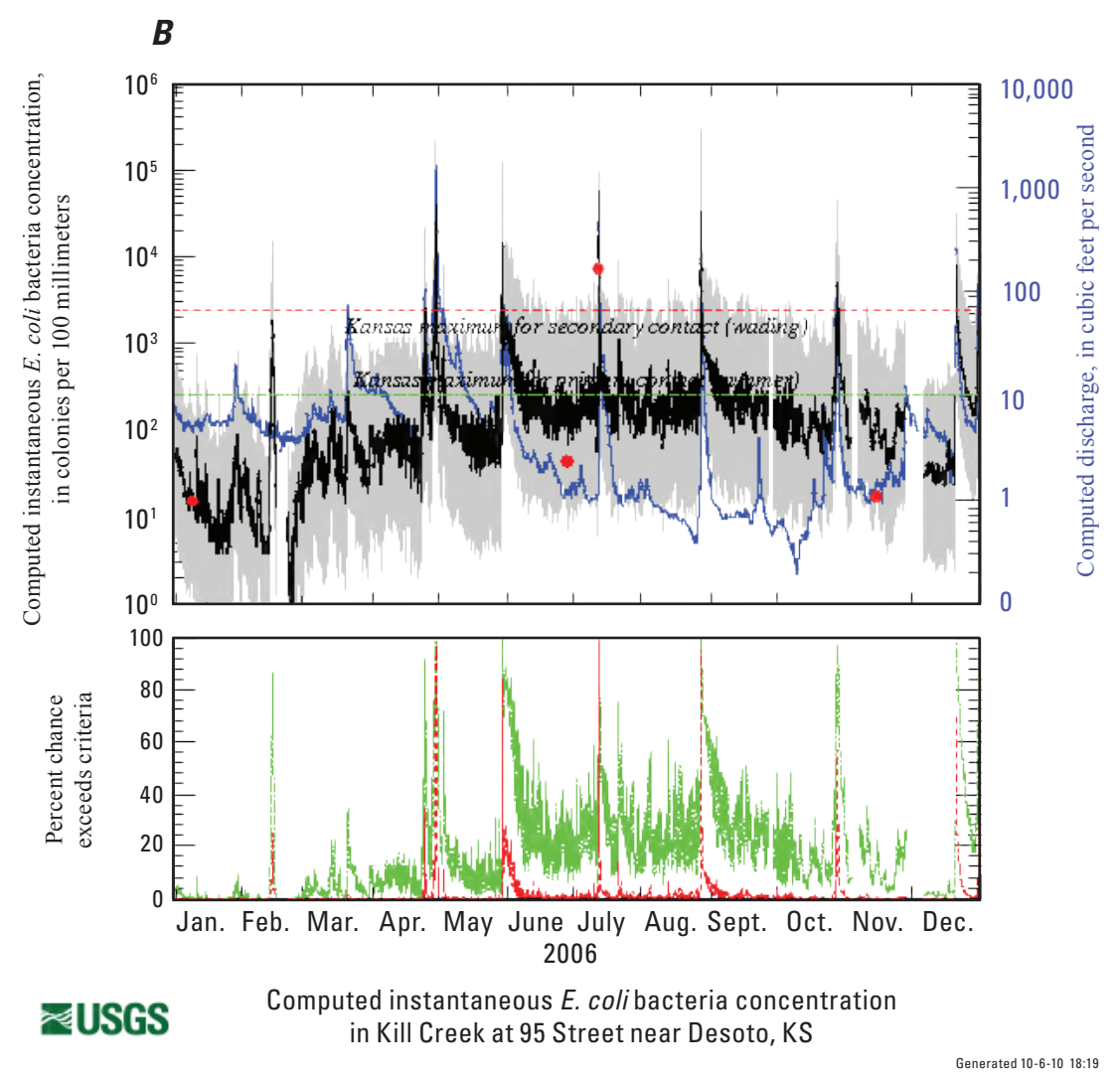

Source http://nrtwq.usgs.gov/ks

\section{EXPLANATION}

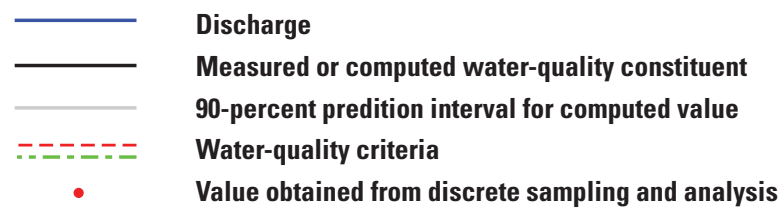

Figure 22. Computed hourly Escherichia coli (E. coli) bacteria density and probability of exceeding primary and secondary contact criteria at the $A$, Indian Creek (largest urban) monitoring site during 2008 and $B$, Kill Creek (smallest rural) monitoring site during 2006, Johnson County, Kansas.-Continued

data. Continuous data are particularly useful for characterizing nonpoint-source contributions from stormwater runoff, which traditionally has been more difficult to monitor than point sources, because the data describe conditions during the duration of each runoff occurrence. Load and yield estimates that are based on continuous data may be more accurate than estimates based on the normally smaller number of discrete samples because the continuous data better capture temporal variability. In addition, constituent variability and loading during specific runoff events can be isolated and evaluated. The data can be used to determine the percentage of time that estimated concentrations or densities exceed existing waterquality criteria, proposed criteria, and established goals.
Transmission of continuous data in real-time makes it possible to rapidly detect and respond to malfunctioning instruments and potential environmental concerns. When continuous data are transmitted in real-time, the information can be used to efficiently time discrete sampling efforts to collect important data during targeted water-quality conditions. In situations where discrete samples and constituent concentration or density data are necessary for regulatory requirements, continuous monitoring allows regulatory agencies to optimize sampling efforts.

As monitoring technologies continue to improve, so does the ability to monitor additional constituents of interest, with smaller measurement error, and at lower operational cost. 

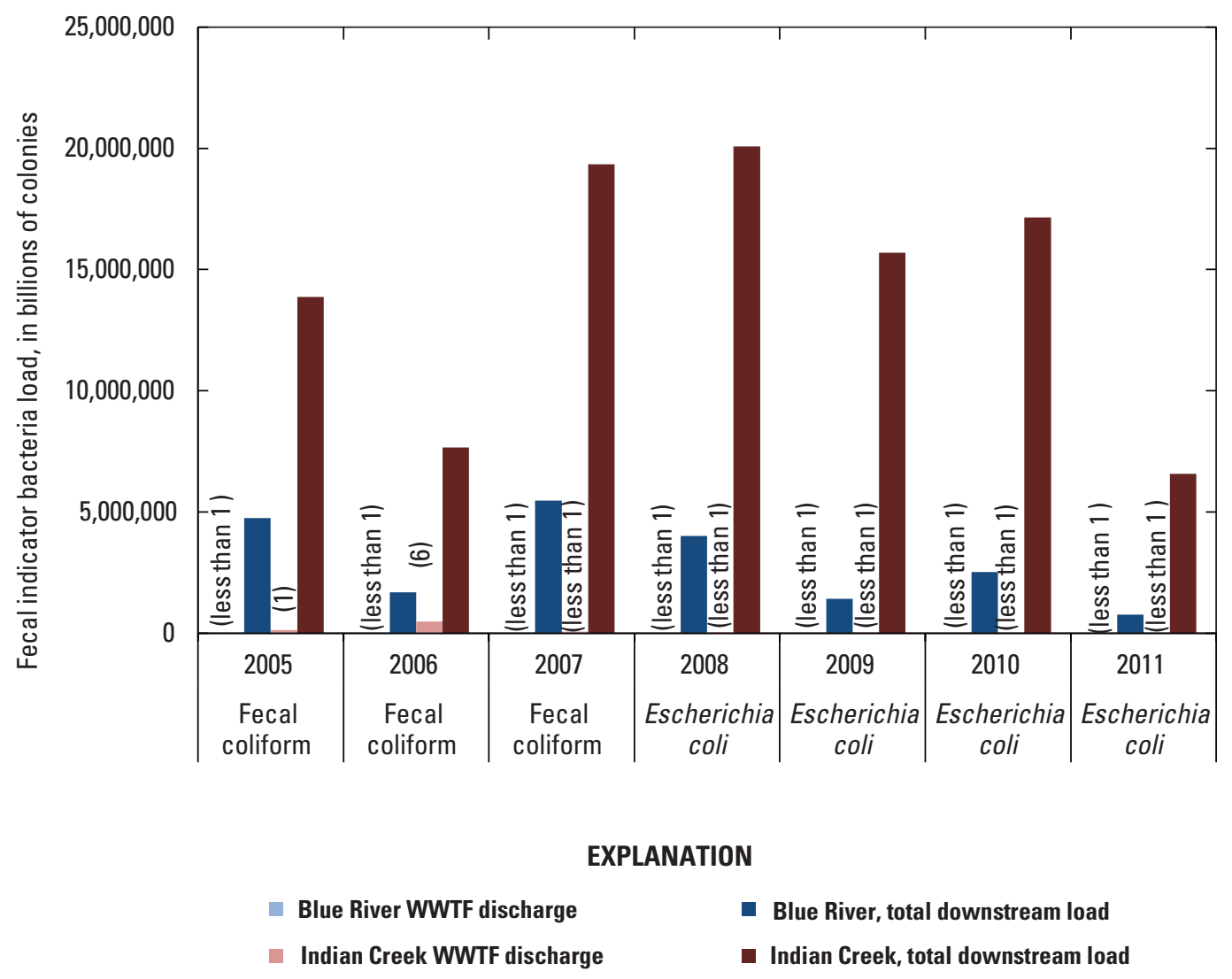

( ) percentage of total from WWTF discharge

Figure 23. Annual fecal indicator bacteria loads originating from wastewater treatment facility (WWTF) discharges compared to total loads in Blue River and Indian Creek, Johnson County, Kansas, 2005-11.

Continuous monitoring has become increasingly common in both research and regulatory applications.

The results presented in this report will be useful to better understand constituent concentration and load fluctuations, range, and variability during changing seasonal and flow conditions and to assess water-quality conditions relative to TMDLs, NPDES requirements, and water-quality standards. The baseline information also is useful for evaluating future changes in land use and effectiveness of implemented BMPs.

\section{Summary and Conclusions}

The population of Johnson County increased by about 24 percent between 2000 and 2012. Balancing development with preservation of natural space has long been a priority for County leaders and residents. The U.S. Geological Survey, in cooperation with the Johnson County Stormwater Management Program, began a comprehensive study of Johnson County streams in 2002 to evaluate and monitor changes in stream quality. This report is one of several reports resulting from that study.
The purpose of this report is to describe water-quality variability and constituent transport in streams of Johnson County, Kansas during 2003 through 2011. Water quality is described using continuous in-stream and computed measurements for five sites ranging in land use, representing the largest watersheds in Johnson County, and covering about 75 percent of the County's land surface. The watersheds are of similar size, ranging from 50.1 square miles to 65.7 square miles. The watersheds ranged in urban development from 98.3 percent urban (Indian Creek) to 16.7 percent urban (Kill Creek). Streamflow, pH, water temperature, specific conductance, and turbidity were measured in-stream. Continuous concentrations of chloride, suspended sediment, nutrients (total nitrogen and total phosphorus), and fecal indicator bacteria (Escherichia coli) were computed using regression models previously developed from continuous data in conjunction with discrete water samples. The results are important for understanding variability in concentrations and loads during changing streamflow and seasonal conditions, and to describe differences among sites. In addition, the information can be used to assess water quality relative to total maximum daily loads, National Pollutant Discharge 
Elimination System requirements, water-quality standards, best management practices, and stream management goals.

Water quality varied according to streamflow conditions, amount of urbanization in the watershed, and relative contributions from wastewater treatment facilities and stormwater runoff within each watershed. Indian Creek, one of the largest and most urban watersheds of the five sites monitored, had the largest mean hourly streamflow, streamflow volume, and streamflow yield annually. Generally, as percent impervious surface (a measure of urbanization) increased, streamflow yield increased because impervious surface moves water quickly to streams and reduces infiltration. Wastewater treatment facility discharge helped sustain streamflow at four of the five sites monitored. Hourly values indicated that the water temperature of Indian Creek was higher than the other sites about 50 percent of the time when temperatures were less than about 15 degrees Celsius.

During the monitoring period for each site, dissolved oxygen concentrations were less than the minimum State criterion of 5 milligrams per liter about 15 percent of the time at the urban Indian Creek site, about 10 percent of the time at the rural Blue River and Kill Creek sites, and less than 5 percent of the time at the other sites. Low dissolved oxygen at all sites generally coincided with lower streamflow and higher water temperatures resulting in decreased oxygen solubility in water. More frequent low dissolved oxygen at Indian Creek likely was caused by wastewater treatment facility discharges and other urban sources that contribute nutrients thereby increasing growth of microorganisms that consume nutrients and reduce dissolved oxygen. Dissolved oxygen was most frequently less than $5 \mathrm{mg} / \mathrm{L}$ during years corresponding with lowest streamflow. Hourly dissolved oxygen concentrations less than $5 \mathrm{mg} / \mathrm{L}$ were measured at all sites every year, indicating that even under optimal climate conditions in undeveloped watersheds such as Kill Creek, dissolved oxygen concentrations may not meet the State aquatic-life criterion.

Specific conductance was nearly always largest in Indian Creek, the most urban stream, followed by Mill Creek, the second most urban stream. Both streams also have the largest contribution of wastewater treatment facility discharge. Higher specific conductance in Cedar Creek than the other two rural sites (Blue River and Kill Creek) all of the time may be a result of larger contribution from groundwater at that site, or may be indicative of road-salt residual affecting stream conditions during the remainder of the year.

Because specific conductance was the explanatory variable for chloride, variability in chloride concentrations at monitoring sites occurred in patterns similar to those for specific conductance. The largest chloride concentrations and variability were recorded at urban sites and during winter. Each winter (December, January, February) during the study period, hourly computed chloride concentrations in Indian Creek exceeded the U.S. Environmental Protection Agencyrecommended criterion of $230 \mathrm{mg} / \mathrm{L}$ for at least 10 consecutive days, and during most winters the criterion was exceeded for at least 30 consecutive days.
The Indian Creek site had the lowest turbidity most of the time because of the high clarity of wastewater treatment facility discharge that dominates streamflow at that site most of the time. During the monitored periods for each site, the U.S. Environmental Protection Agency-recommended ecoregion criterion was exceeded 30 (Indian Creek) to 50 (Blue River) percent of the time. Regression models for suspendedsediment concentration (SSC) use turbidity as the single explanatory variable. The highest average annual streamflowweighted suspended-sediment concentration during the study period was in Mill Creek which has undergone rapid development that likely contributed to higher sediment concentrations. Annual suspended-sediment loads were always largest at the Indian Creek site, which carries the largest streamflow volume. The largest load event in Indian Creek was recorded in early May 2007 when about 20,000 tons of sediment (about 25 percent of the total annual load) were transported during a period of 2.25 days. A simultaneous load event was recorded in Kill Creek, when about 75 percent of the total annual sediment load (about 15,000 tons) was transported. Each of the other watersheds also experienced runoff events when a large percentage of the annual load was transported. Sediment yields generally increased as percent impervious surface increased. Annual sediment yields were less variable at urban sites than at nonurban sites.

Computed hourly total nitrogen and total phosphorus concentrations during the study period generally were highest at the Indian Creek site. Median annual total nitrogen concentrations in Indian Creek were about three times higher than median annual total nitrogen concentrations in Mill Creek, and at least seven times higher than median annual total nitrogen concentrations in Blue River and Kill Creek. Streamflowweighted concentrations of total nitrogen and total phosphorus also generally were largest in Indian and Mill Creeks. Annual percent contribution of total nitrogen in the Blue River from wastewater treatment facility discharges ranged from 19 percent (50 tons) in 2010 to 60 percent in 2006 . Annual percent contribution of total nitrogen in Indian Creek from wastewater treatment discharges ranged from 35 percent ( 250 tons) in 2010 to 93 percent (300 tons) in 2006. Large percent contributions in both watersheds were recorded during 2006 and 2011 when the smallest precipitation and streamflow volume occurred, resulting in less contribution originating from runoff. Annual percent contribution of total phosphorus in the Blue River from wastewater treatment facility discharges ranged from 18 percent ( 5 tons) in 2010 to 46 percent ( 10 tons) in 2006. Annual percent contribution of total phosphorus in Indian Creek from wastewater treatment facility discharges ranged from 39 percent (about 40 tons) in 2010 to more than 100 percent (about 75 tons) in 2006. Larger total phosphorus load in Indian Creek wastewater discharge than at the downstream monitoring site in 2006 (when the lowest streamflow conditions occurred) may be a result of uncertainty in the load estimation or phosphorus uptake that occurred within the distance between the wastewater treatment facility discharges 
and the monitoring sites, with less flushing from stormwater runoff.

Escherichia coli density at the urban Indian Creek site was usually the largest of the five monitoring sites with a median density that exceeded the primary contact criterion value but was less than the secondary contact criterion each year. The Blue River and Cedar Creek sites had the lowest bacteria densities most of the time. Average annual bacteria load and yield in Indian Creek was more than three times any other site. Less than 1 percent of the total downstream Blue River and Indian Creek indicator bacteria load originated from wastewater treatment facility discharges, except during 2006 when about 6 percent of the Indian Creek load originated from wastewater.

Continuous water-quality monitoring provides a foundation for comprehensive evaluation and understanding of variability and loading characteristics in streams of Johnson County. Because several directly measured parameters (such as specific conductance and turbidity) are strongly correlated with particular constituents of interest (such as chloride, suspended sediment, nutrients, and fecal-indicator bacteria), regression models provide a valuable tool for evaluating variability and loading on the basis of computed continuous data. Continuous data are particularly useful for characterizing nonpoint-source contributions from stormwater runoff. Transmission of continuous data in real-time makes it possible to rapidly detect and respond to potential environmental concerns and malfunctioning instruments. As monitoring technologies continue to improve, so does the ability to monitor additional constituents of interest, with smaller measurement error, and at lower operational cost. Continuous water-quality data including model information and computed concentrations and loads during the study period are available at http://nrtwq.usgs.gov/ $k s /$.

\section{References Cited}

American Public Health Association, American Water Works Association, and Water Environment Association, 1995, Standard methods for the examination of water and wastewater (18th ed.): Washington, D.C., American Public Health Association, $905 \mathrm{p}$.

Anderson, C.W., 2005, Turbidity, in National field manual for the collection of water-quality data: U.S. Geological Survey Techniques of Water-Resources Investigations, book 9, chap. 6.7 , p. 1-59.

ASTM International, 2003, D1889-00 standard test method for turbidity of water, in ASTM International, Annual book of ASTM standards, water and environmental technology: West Conshohocken, Pennsylvania, v. 11.01, 6 p.
Brown, L.R., Cuffney, T.E., Coles, J.F., Fitzpatrick, F., McMahon, G., Steuer, J., Bell, A.H., and May, J.T., 2009, Urban streams across the USA-Lessons learned from studies in 9 metropolitan areas: Journal of the North American Benthological Society, v. 28, no. 4, p. 1051-1069.

Christensen, V.G., Jian, X., and Ziegler, A.C., 2000, Regression analysis and real-time water-quality monitoring to estimate constituent concentrations, loads, and yields, in the Little Arkansas River, south-central Kansas, 1995-99: U.S. Geological Survey Water-Resources Investigations Report 00-4126, $36 \mathrm{p}$.

Coles, J.F., McMahon, Gerard, Bell, A.H., Brown, L.R., Fitzpatrick, F.A., Scudder Eikenberry, B.C., Woodside, M.D., Cuffney, T.F., Bryant, W.L., Cappiella, Karen, FraleyMcNeal, Lisa, and Stack, W.P., 2012, Effects of urban development on stream ecosystems in nine metropolitan study areas across the United States: U.S. Geological Survey Circular 1373, 138 p.

Corsi, S.R., Graczyk, D.J., Geis, S.W., Booth, N.L., and Richards, K.D., 2010, A fresh look at road salt-Aquatic toxicity and water-quality impacts on local, regional and national scales: Environmental Science and Technology, v. 44, no. 19, p. 7376-7382.

Devlin, D.L., and McVay, K.A., 2001, Suspended solids-A water quality concern for Kansas: Kansas State University Agricultural Experiment Station and Cooperative Extension Service, TMDL Fact Sheet No. 6, 2 p.

Dufour, A.P., 1977, Escherichia coli-fecal coliform, in Hoadley, A.W., and Dutka, B.J., eds., Bacterial indicator/health hazards associated with water, 1977: American Society for Testing and Materials, ASTM STP 635, p. 48-58.

Edwards, K.E., and Glysson, G.D., 1999, Field methods for measurement of fluvial sediment: U.S. Geological Survey Techniques of Water-Resources Investigations, book 3 , chap. C2, 89 p.

Faires, L.M., 1993, Methods of analysis by the U.S. Geological Survey National Water-Quality Laboratory-Determination of metals in water by inductively coupled plasma-mass spectrometry: U.S. Geological Survey Open-File Report 92-634, $28 \mathrm{p}$.

Fishman, M.J., ed., 1993, Methods of analysis by the U.S. Geological Survey National Water-Quality LaboratoryDetermination of inorganic and organic constituents in water and fluvial sediments: U.S. Geological Survey OpenFile Report 93-125, 217 p.

Fishman, M.J., and Friedman, L.C., 1989, Methods for determination of inorganic substances in water and fluvial sediments: U.S. Geological Survey Techniques of WaterResources Investigations, book 5, chap. A1, 545 p. 
Francy, D.S., and Darner, R.A., 2006, Procedures for developing models to predict exceedences of recreational waterquality standards at coastal beaches: U.S. Geological Survey Techniques and Methods, book 6, chap. B5, 34 p.

Galli, F.J., 1991, Thermal impacts associated with urbanization and stormwater management best management practices: Washington, D.C., Metropolitan Washington Council of Governments, p. 123-141.

Glasgow, H.B., Burkholder, J.M., Reed, R.E., Lewitus, A.J., and Kleinman, J.E., 2004, Real-time remote monitoring of water quality-A review of current applications, and advancements in sensor, telemetry, and computing technologies: Journal of Experimental Marine Biology and Ecology, v. 300 , p. $409-448$.

Graham, J.L., Stone, M.L., Rasmussen, T.J., and Poulton, B.C., 2010, Effects of wastewater effluent discharge and treatment facility upgrades on environmental and biological conditions of the Upper Blue River, Johnson County, Kansas and Jackson County, Missouri, January 2003 through March 2009: U.S. Geological Survey Scientific Investigations Report 2010-5248, 85 p.

Gray, J.R., Glysson, G.D., Turcios, L.M., and Schwarz, G.E., 2000, Comparability of suspended-sediment concentration and total suspended solids data: U.S. Geological Survey Water-Resources Investigations Report 00-4191, 14 p.

Guy, H.P., 1969, Laboratory theory and methods for sediment analysis: U.S. Geological Survey Techniques of WaterResources Investigations, book 5, chap. C1, 58 p.

Helsel, D.R., and Hirsch, R.M., 2002, Statistical methods in water resources-hydrologic analysis and interpretation: Techniques of Water-Resources Investigations of the U.S. Geological Survey, book 4, chap. A3, 510 p.

Hem, J.D., 1992, Study and interpretation of chemical characteristics of natural water (3d ed.): U.S. Geological Survey Water-Supply Paper 2254, 263 p.

Hession, W.C., Pizuto, J.E., Johnson, T.E., and Horwitz, R.J., 2003, Influence of bank vegetation on channel morphology in rural and urban watersheds: Geology, v. 31, p. 147-150.

Johnson County Parks and Recreation District, 2001, MAP 2020 Master Action Plan, Johnson County, Kansas: Accessed July 28, 2012, at http://jcprd.com/pages/ download.cfm.

Johnson County Public Works and Infrastructure, 2013, Stormwater Program Overview: Accessed December 2013, at http://publicworks.jocogov.org/stormwater.

Jordan, P.R., and Stamer, J.K., eds., 1995, Surface-water-quality assessment of the lower Kansas River Basin, Kansas and Nebraska, analysis of data through 1986: U.S. Geological Survey Water-Supply Paper 2352-B, 161 p.
Kansas Department of Health and Environment, 2010, Kansas 2010 303(d) list of impaired waters: Accessed February 2011 at http://www.kdheks.gov/tmdl/methodology.htm.

Kansas Department of Health and Environment, 2004, Surface Water Nutrient Reduction Plan, December 2004: Accessed April 2011 at $h t t p: / / w w w 2 . e p a . g o v / s i t e s / p r o d u c t i o n / f i l e s /$ documents/ksplan2004.pdf.

Kansas Department of Health and Environment, 2005, Kansas Administrative Regulations (KAR), Title 28, Article 16, Surface water quality standards 2005: Topeka, Kansas, Secretary of State, multiple pagination.

Kansas Department of Health and Environment, 2012, Kansas integrated water quality assessment: Accessed June 2012 at $h t t p: / / w w w . k d h e k s . g o v /$ befs/download/ Kansas_2012IntegratedReport.pdf.

Kaushal, S.S., Groffman, P.M., Likens, G.E., Belt, K.T., Stack, W.P., Kelly, W.K., Band, L.E., and Fisher, G.T., 2005, Increased salinization of fresh water in the northeastern United States: Proceedings of National Academy of Sciences, v. 102, p. 13517-13520.

Kaushal, S.S. Likens, G.E., Jaworski, N.A., Pace, M.L., Sides, A.M., Seekell, D., Belt, K.T, Secor, D.H., and Wingate, R.L., 2010, Rising stream and river temperatures in the United States: Frontiers in Ecology and the Environment, v. 8, no. 9, p. 461-466.

Kittrel, F.W., and Furfari, S.A., 1963, Observations of coliform bacteria in streams: Journal of Water Pollution Control Federation, v. 35, p. 1361-1385.

LeBlanc, R.T., Brown, R.D., and Fitzgibbon, J.E., 1997, Modeling the effects of land use change on water temperature in unregulated urban streams: Journal of Environmental Monitoring, v. 49, p. 445-469.

Lee, C.J., Mau, D.P., and Rasmussen, T.J., 2005, Effects of point and nonpoint sources on water quality and relation to land use in Johnson County, northeastern Kansas, October 2002 through June 2004: U.S. Geological Survey Scientific Investigations Report 2005-5144, 104 p.

Lee, C.J., Rasmussen, P.P., Ziegler, A.C., and Fuller, C.C., 2009, Transport and sources of suspended sediment in the Mill Creek watershed, Johnson County, northeast Kansas, 2006-07: U.S. Geological Survey Scientific Investigations Report 2009-5001, 52 p.

Leopold, L.B., 1968, Hydrology for urban planning-A guidebook on the hydrologic effects of urban land use: U.S. Geological Survey Circular 554, 18 p.

Leopold, L.B., Huppman, R., and Miller, A., 2005, Geomorphic effects of urbanization in forty-one years of observation: Proceedings of the American Philosophical Society, v. 149, no. 3, p. 349-371. 
Loperfido, J.V., Just, C.L., Papanicolaou, A.N., and Schnoor, J.L., 2010, In situ sensing to understand diel turbidity cycles, suspended solids, and nutrient transport in Clear Creek, Iowa: Water Resources Research, v. 46, 8 p.

Lundquist, J.D., and Cayan, D., 2002, Seasonal and spatial patterns in diurnal cycles in streamflow in the Western United States: Journal of Hydrometeorology, v. 3, p. 591-602.

Maidment, 1993, Handbook of hydrology: New York, McGraw-Hill, Inc., variously paged.

Masters, G.M., 1991, Introduction to environmental engineering and science: Englewood Cliffs: New Jersy, Prentice Hall, p. 110-111.

National Weather Service, 2012, NOAA Online Weather Data: National Oceanic and Atmospheric Administration database, accessed December 2012 from http://www.nws.noaa.gov/ climate/xmacis.php? wfo $=$ eax.

Paul, M.J., and Meyer, J.L., 2001, Streams in the urban landscape: Annual Review of Ecological Systems, v. 32, p. 333-65.

Perry, C.A., Wolock, D.M., and Artman, J.A., 2004, Estimates of flow duration, mean flow, and peak-discharge frequency values for Kansas stream locations: U.S. Geological Survey Scientific Investigations Report 2004-5033, 219 p.

Peterson, D.L., Whistler, J.L., Egbert, S.L., and Martinko, E.A., 2010, 2005 Kansas land cover patterns phase II Final Report, KBS Report \#167: Kansas Biological Survey, University of Kansas, $49 \mathrm{p}$.

Poulton, B.P., Rasmussen, T.J., and Lee, C.J., 2007, Assessment of biological conditions at selected stream sites in Johnson County, Kansas, and Cass and Jackson Counties, Missouri, 2003 and 2004: U.S. Geological Survey Scientific Investigations Report 2007-5108, 68 p.

Rasmussen, P.P., and Ziegler, A.C., 2003, Comparison and continuous estimates of fecal coliform and Escherichia coli bacteria in selected Kansas streams, May 1999 through April 2002: U.S. Geological Survey Water-Resources Investigations Report 03-4056, $80 \mathrm{p}$.

Rasmussen, T.J., Lee, C.J., and Ziegler, A.C., 2008, Estimation of constituent concentrations, densities, loads, and yields in streams of Johnson County, northeastern Kansas, using regression models and continuous water-quality monitoring, October 2002 through December 2006: U.S. Geological Survey Scientific Investigations Report 2008-5014, 103 p.

Rasmussen, T.J., Poulton, B.C., and Graham, J.L., 2009a, Quality of streams in Johnson County, Kansas, and relations to environmental variables, 2003-07: U.S. Geological Survey Scientific Investigations Report 2009-5235, 95 p.
Rasmussen, P.P., Gray, J.R., Glysson, G.D., and Ziegler, A.C., 2009b, Guidelines and procedures for computing time-series suspended-sediment concentrations and loads from in-stream turbidity-sensor and streamflow data: U.S. Geological Survey Techniques and Methods, book 3, chap. $\mathrm{C} 4,53 \mathrm{p}$.

Rasmussen, T.J., Stone, M.S., Poulton, B.C., and Graham, J.L., 2012, Quality of streams in Johnson County, Kansas, 2002-10: U.S. Geological Survey Scientific Investigations Report 2012-5279, $103 \mathrm{p}$.

Rounds, S.A., Wilde, F.D., and Ritz, G.F., 2013, Dissolved oxygen (ver. 3.0): U.S. Geological Survey Techniques of Water-Resources Investigations, book 9, chap. A6, sec. 6.2: Accessed October 2013 from http://water.usgs.gov/owq/ FieldManual/Chapter6/6.2_contents.html.

Smith, R.A., Alexander, R.B., and Schwartz, G.E., 2003, Natural background concentrations of nutrients in streams and rivers of the conterminous United States: Environmental Science and Technology, v. 37, no. 14, p. 3039-3047.

Turnipseed, D.P., and Sauer, V.B., 2010, Discharge measurements at gaging stations: U.S. Geological Survey Techniques and Methods, book 3, chap. A8, 87 p.

U.S. Census Bureau, 2012, State and county quickfacts: Accessed July 24, 2012, at http://quickfacts.census.gov/qfd/ states/20000.html.

U.S. Department of Agriculture, 2007, Kansas Annual Precipitation: Accessed August 2011 at ftp://ftp-fc.sc.egov.usda. gov/KS/Outgoing/Web_Files/Technical_Resources/Maps/ ks_08_22.pdf.

U.S. Environmental Protection Agency, 2002a, List of drinking water contaminants \& MCLs, July 2002: Washington, D.C., EPA-816-F-02-013, accessed July 1, 2011, at $h t t p: / /$ www.epa.gov/safewater/mcl.html.

U.S. Environmental Protection Agency, 2002b, Source Water Protection Practices Bulletin-Managing highway deicing to prevent contamination of drinking water: Washington, D.C., EPA 816-F-02-019, 7 p.

U.S. Environmental Protection Agency, 2003, Ecoregion criteria: Accessed November 2011 at http://water.epa.gov/ scitech/swguidance/standards/criteria/nutrients/ecoregions/ index.cfm.

U.S. Geological Survey, 2006, Collection of Water Samples (ver. 2.0): U.S. Geological Survey Techniques of WaterResources Investigations, book 9, chap. A4: Accessed October 2013 from http://water.usgs.gov/owq/FieldManual/ chapter4/pdf/Chap4_v2.pdf. 
Wagner, R.J., Boulger, R.W., Jr., Oblinger, C.J., and Smith, B.A., 2006, Guidelines and standard procedures for continuous water-quality monitors: station operation, record computation, and data reporting: U.S. Geological Survey Techniques and Methods, book 1, chap. D3, 96 p.

Walters, D.M., Leigh, D.S., and Bearden, A.B., 2003, Urbanization, sedimentation, and the homogenization of fish assemblages in the Etowah River Basin, USA: Hydrobiologia, v. 494, p. 5-10.

Waters, T.F., 1995, Sediment in streams - Sources, biological effects, and control: American Fisheries Society, monograph 7, Bethesda, Maryland, $251 \mathrm{p}$.

Webb, B.W., Hannah, D.M., Moore, R.D., Brown, L.E., and Nobilis, F., 2008, Recent advances in stream and river temperature research: Hydrological Processes, v. 22, p. 902-918.

Welch, E.B., and Lindell, T., 1992, Ecological effects of wastewater, applied limnology and pollutant effects: London and New York, Cambridge University Press, 425 p.

Wetzel, R.G., 2001, Limnology of lake and river ecosystems: New York, Academic Press, 1,006 p.
Wilde, F.D., 2006, Temperature (ver. 3.0): U.S. Geological Survey Techniques of Water-Resources Investigations, book 9, chap. A6., sec. 6.1, March 2006, accessed October 2013 from http://pubs.water.usgs.gov/twri9A6/.

Wilkison, D.H., D.J. Armstrong, and D.W. Blevins, 2002, Effects of wastewater and combined sewer overflows on water quality in the Blue River basin, Kansas City, Missouri and Kansas, July 1998-October 2000: U.S. Geological Survey Water Resources Investigations Report 02-4107, 162 p.

Wilkison, D.H., Armstrong, D.J., Norman, R.D, Poulton, B.C., Furlong, E.T., and Zaugg, S.D., 2006, Water-quality in the Blue River Basin, Kansas City metropolitan area, Missouri and Kansas, July 1998 to October 2004: U.S. Geological Survey Scientific Investigations Report 2006-5147, 170 p.

Wilkison, D.H., Armstrong, D.J., and Hampton, S.A., 2009, Character and trends of water quality in the Blue River Basin, Kansas City metropolitan area, Missouri and Kansas, 1998 through 2007: U.S. Geological Survey Scientific Investigations Report 2009-5169, 211 p. 
Publishing support provided by:

Pembroke and Rolla Publishing Service Center

For additional information concerning this publication, contact:

Director, USGS Kansas Water Science Center

4821 Quail Crest Place

Lawrence, KS 66049

(785) 842-9909

Or visit the Kansas Water Science Center Web site at: http://ks.water.usgs.gov/ 



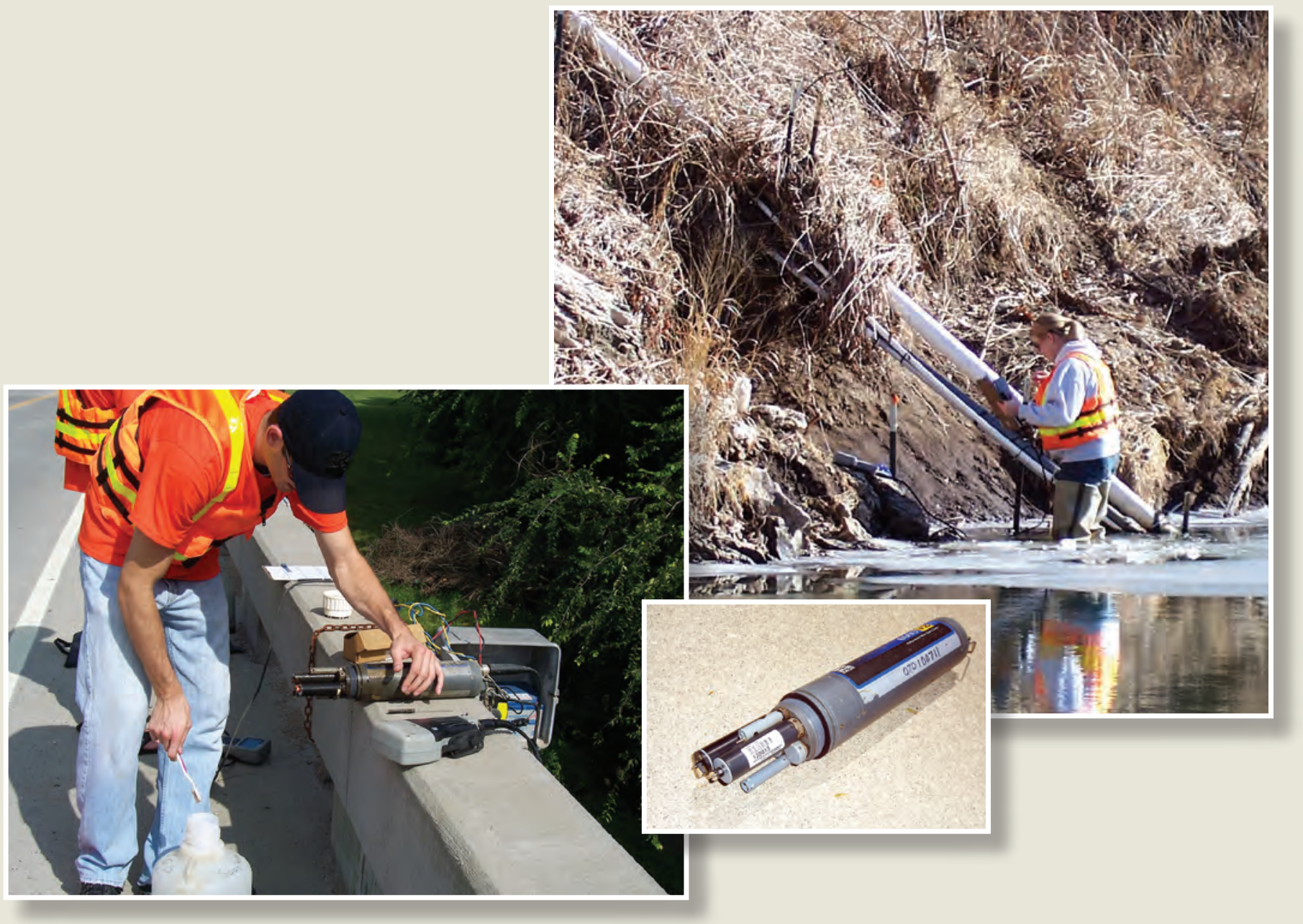

